
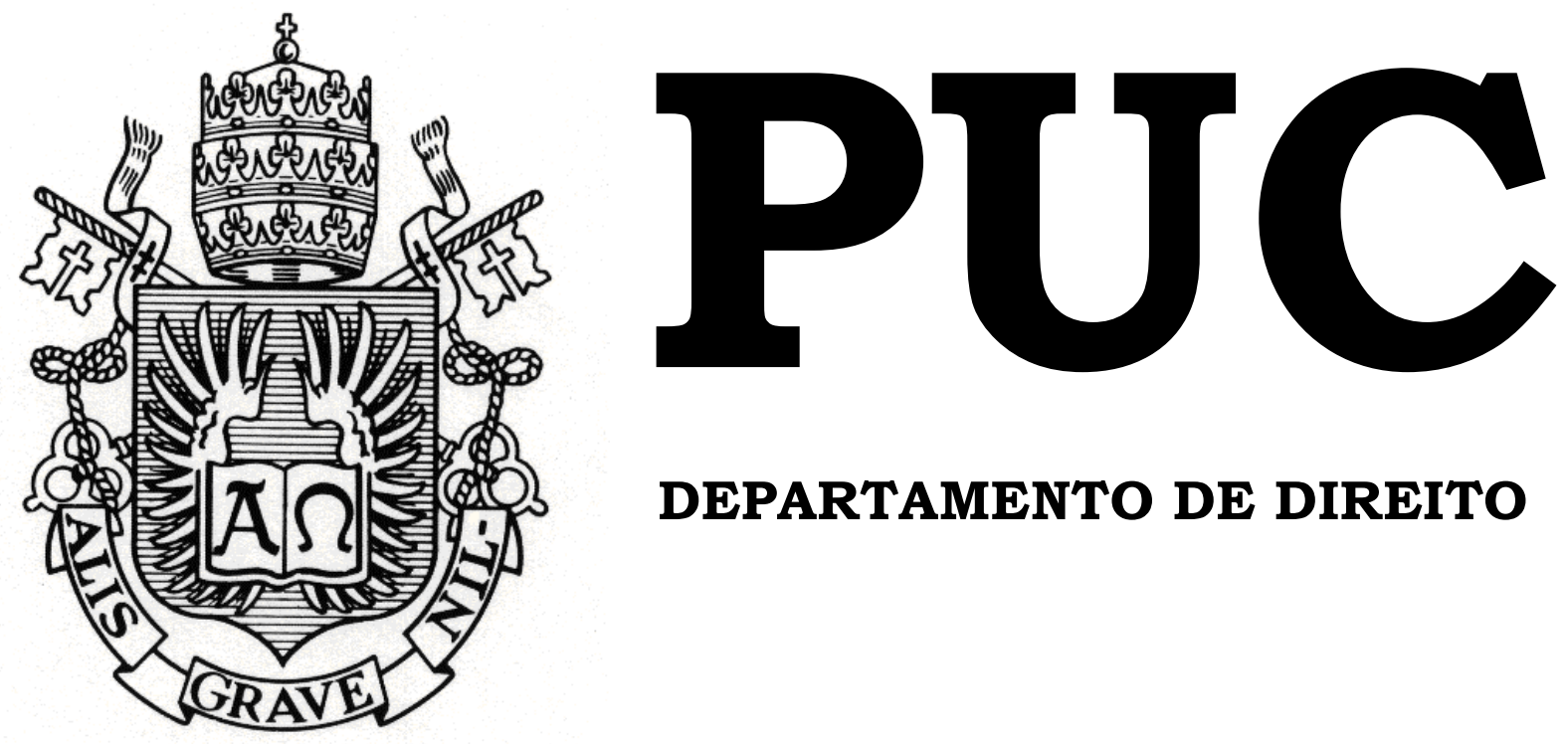

DEPARTAMENTO DE DIREITO

\title{
O TRIBUNAL PENAL INTERNACIONAL: SUA ORIGEM, CONSOLIDAÇÃO E RELAÇÃO COM O SISTEMA NORMATIVO BRASILEIRO
}

Por

BRUNO ATHAYDE CAMILLO

ORIENTADOR: PROF. ADOLFO BORGES

2010.1

PONTIFÍCIA UNIVERSIDADE CATÓLICA DO RIO DE JANEIRO

RUA MARQUÊS DE SÃO VICENTE, 225 - CEP 22453-900

RIO DE JANEIRO - BRASIL 


\title{
O TRIBUNAL PENAL INTERNACIONAL: SUA ORIGEM, CONSOLIDAÇÃO E RELAÇÃO COM O SISTEMA NORMATIVO BRASILEIRO
}

\author{
por \\ BRUNO ATHAYDE CAMILLO
}

Monografia apresentada ao Departamento de Direito da Pontificia Universidade Católica do Rio de Janeiro (PUC-Rio) como requisito para obtenção do Título de Bacharel em Direito.

Orientador: PROF. ADOLFO BORGES

2010.2 
Ao meu avô, Calil (in memorian), obrigado pelo seu carinho e sorriso sincero.

Ao meu primo Joaquim (in memorian), que estaria terminando sua monografia possivelmente na mesma época que eu. 


\section{Agradecimentos}

Aos meus pais, Guilhermina e Carlos Roberto, pelo amor incondicionado, carinho, dedicação e apoio ao longo desses anos.

À minha namorada, Sandra, pela compreensão e amor, que não se apaga pela distância.

Aos Professores que fizeram a diferença na minha vida (profs. Márcia, Rosaine Gustavo, David, Luiz Antonio Valladão, Gustavo Sénéchal e Adolfo Borges).

Ao meu amigo Thomas, obrigado pela "paciência de Jó" ao me ajudar a formatar este texto.

Àqueles que se foram e deixaram saudades. 
Silent enim leges inter arma

CÍCERO, Pro Milone 4.11 


\section{Resumo}

O presente trabalho tem como objetivo discursar sobre os caminhos que terminaram por criar um Tribunal Penal permanente junto ao direito internacional, fruto de inúmeros tratados históricos -antigos e recentesentre Estados, bem como consequência de inúmeras atrocidades cometidas pelas mesmas entidades soberanas ao longo dos séculos, em especial do século passado, onde o incrível avanço nas mais diversas áreas da tecnologia, do saber e da medicina não puderam prevenir o massacre de milhões de inocentes nos mais diferentes ambientes habitados pela espécie humana.

Serão analisados, também, a criação dos Tribunais Militares de Nuremberg e Tóquio, os Tribunais ad hoc (de exceção) criados pela ONU (para os crimes cometidos em Ruanda e antiga Iugoslávia), bem como a formação do Estatuto de Roma (sua vigência, mecanismos de cooperação internacional, funcionamento, responsabilidade pessoal dos violadores de direitos humanos etc.), documento essencial que deu origem ao TPI.

Nessa caminhada (ao que tudo indica) irreversível pela jurisdicionalização do Direito Internacional, onde a Justiça Internacional já se opera uma realidade, apesar das resistências, em que a sociedade internacional se depara frente à uma nova realidade em que a defesa dos direitos humanos adquire contornos supranacionais, iremos analisar, por fim, o papel do Estado Brasileiro nesse cenário, que aderiu ao Tratado de Roma e, aparentemente, poderia vir a enfrentar problemas em assimilar partes desse tratado ao seu ordenamento jurídico interno, envolvendo questões polêmicas tais como a prisão perpétua, as imunidades, entrega de nacionais ao Tribunal, bem como os princípios da reserva legal e da coisa julgada. 
Palavras-chave: TPI; Tratado de Roma; Direitos Humanos; Tribunal ad hoc; Cooperação Jurídica Internacional; Crimes Contra a Humanidade; ONU; Estado; Soberania;Genocídio; Segurança Internacional 


\section{Sumário}

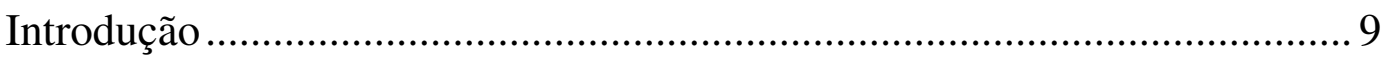

1. Gênese da Justiça Penal Internacional: Antecedentes Históricos ............ 14

1.1 O Surgimento da Idéia de uma Jurisdição Internacional ..................... 14

1.2 Os Direitos Humanos no pós $1^{\mathrm{a}}$ Guerra Mundial................................. 15

1.3. Os Tribunais Militares no pós $2^{\mathrm{a}}$ Guerra Mundial .............................. 19

1.3.a. O Tribunal Militar de Nuremberg ..................................................... 21

1.3.b. Tribunal Militar Internacional para o Extremo Oriente.................. 27

1.4. Os Tribunais ad hoc e o papel do Conselho de Segurança da ONU. 30

1.4.a O Tribunal ad hoc para a antiga Iugoslávia ...................................... 30

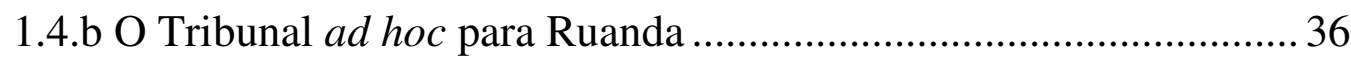

2. O Estatuto de Roma e a Criação do Tribunal Penal Internacional ........... 42

2.1. Aprovação e entrada em vigor do Estatuto de Roma.......................... 44

2.2 Estrutura e funcionamento do Tribunal ............................................... 48

3. Pressupostos da cooperação jurídica internacional ..................................52

3.1. Princípios da cooperação jurídica internacional ................................. 54

3.2. Cooperação Jurídica Internacional na esfera penal.............................55

4. Fundamentos do Tribunal Penal Internacional......................................... 62

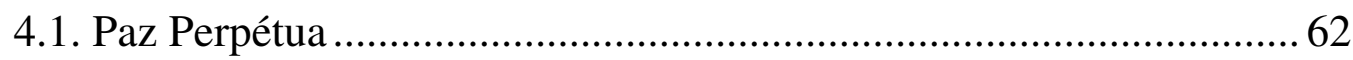

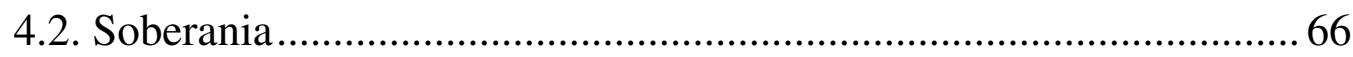

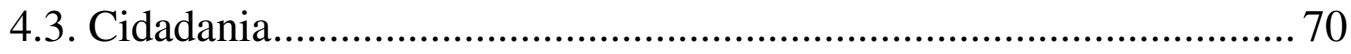

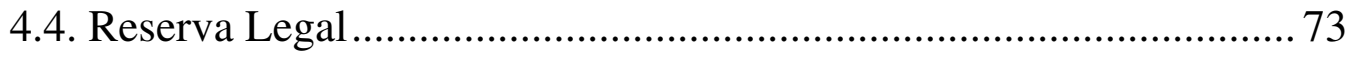

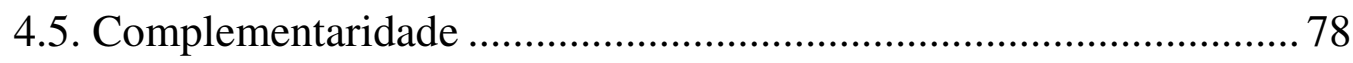

5. Os crimes previstos pelo Estatuto de Roma .............................................. 83 


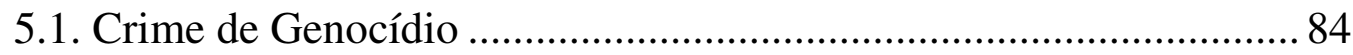

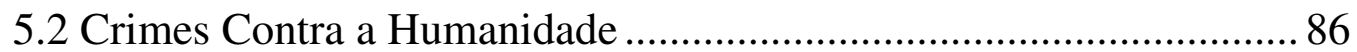

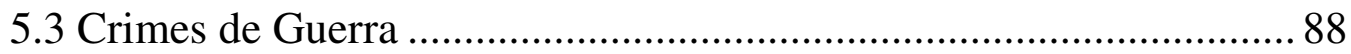

5.4 Crime de Agressão .............................................................................. 90

6. A incorporação do Estatuto de Roma ao Ordenamento Jurídico

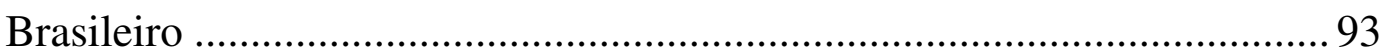

6.1 Imunidade Parlamentar ...................................................................... 93

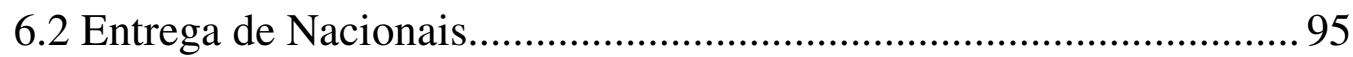

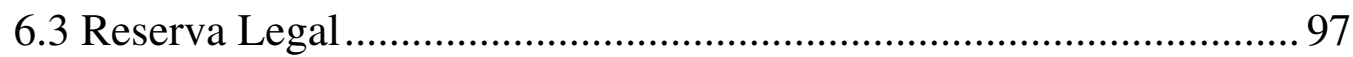

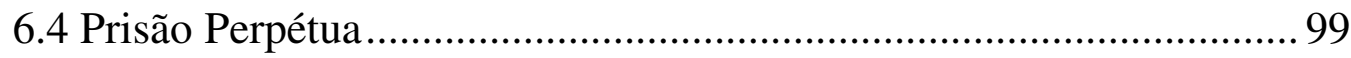

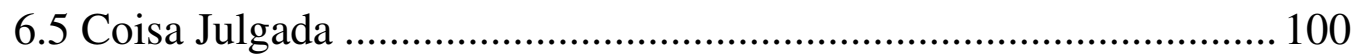

CONCLUSÃO

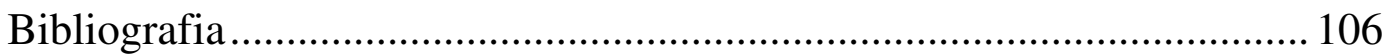




\section{Lista de Abreviaturas}

Art.: Artigo

TPI: Tribunal Penal Internacional

CF: Constituição da República Federativa do Brasil de 1988

Min.: Ministro

STF: Superior Tribunal Federal

ONU: Organização das Nações Unidas

TMI: Tribunal Militar Internacional

URSS: União das Repúblicas Socialistas Soviéticas

CCL10: Allied Control Council Law n.10

ICTY: International Criminal Tribunal for former Iugoslavia (Tribunal ad hoc para a ex-Iugoslávia)

FRP: Frente Patriótica Ruandesa

RDC: República Democrática do Congo

ICTR: Tribunal Penal Internacional para Ruanda

CPP: Código de Processo Penal Brasileiro

CP: Código Penal Brasileiro 


\section{Introdução}

A guerra sempre fez parte da realidade humana. A partir do momento em que os primeiros hominídeos aprenderam, a milhões de anos atrás, a manipular objetos, eles não só se consolidaram no topo da cadeia alimentar, contribuindo em muito para a difusão da espécie ao redor do planeta, como criaram formas mais evoluídas de se relacionar conforme os vínculos que possuíam uns com os outros. Essas formas de relacionamento cresceram junto com a expansão da espécie humana, inicialmente concentrada, ao que tudo indica, em uma determinada área do continente africano; semi-coletores e caçadores, os primeiros hominídeos deram início aos conflitos da espécie, onde um grupo familiar, no sentido mais amplo do termo ${ }^{1}$, expulsava outro grupo indesejado das terras por eles agora exploradas, valendo-se de suas primitivas armas para impor aos derrotados o que hoje se é tido como as primeiras violações dos direitos humanos. Antes de se produzir equipamentos para o plantio, os primeiros hominídeos usaram sua criatividade para a criação de objetos ${ }^{2}$ que os ajudassem a matar.

O belicismo sempre foi uma característica notoriamente humana. Ela afligiu toda a nossa história, desde o princípio, tendo sempre as mesmas características: sempre foi utilizada tendo como fim a conquista territorial e a subjugação de um povo a outro. Entretanto, foi no século XX que se presenciou as mais dramáticas transformações da história da humanidade. Nunca num período tão curto de tempo (histórico) obteve-se tantas conquistas nos mais variados campos do saber; tantas descobertas, tantas promessas para a humanidade não foram capazes de evitar a maior

\footnotetext{
${ }^{1}$ http://www.priberam.pt/dlpo/default.aspx?pal=fam\% C3\% ADlia (acessado dia 29/09/2010)

${ }^{2}$ http://pt.wikipedia.org/wiki/Pr\%C3\%A9-hist\% C3\%B3ria (acessado dia 29/09/2010)
} 
catástrofe da nossa história, onde a sempre imanente mentalidade belicista da espécie humana encontrou os meios agora fornecidos pela tecnologia e política para levar o conflito armado a um outro nível. As duas Grandes Guerras desse século irão redefinir o papel do direito internacional e dos Estados, criando um caminho viável para a implementação de uma jurisdicionalização penal internacional. Nos dizeres de Eric Hobsbawn ${ }^{3}$ :

"A humanidade sobreviveu. Contudo, o grande edifício da civilização do século XX desmoronou nas chamas da guerra mundial, quando suas colinas ruíram. Não há como compreender o Breve Século XX sem ela. Ele foi marcado pela guerra. Viveu e pensou em termos de guerra mundial, mesmo quando os canhões se calavam e as bombas não explodiam. Sua história e, mais especificamente, a história de sua era inicial de colapso e catástrofe devem começar com a guerra mundial de 31 anos."

O período de 31 anos ao que se refere o autor supracitado, que vai do início da $1^{\mathrm{a}}$ Guerra Mundial ao término da $2^{\mathrm{a}}$, é marcado no cenário internacional por uma série de tentativas de se criar uma instância internacional com jurisdição penal (que será elucidado posteriormente nesse trabalho) que ganha forma, embora nunca chegue a efetivamente funcionar, durante a curta existência da Liga das Nações. Essa tentativa ficará "arquivada" no longo período de mais ou menos 40 anos correspondentes à Guerra Fria, onde a divisão do mundo entre dois colossais eixos políticoideológicos terminará por deixar inviável qualquer tentativa de se implementar uma Corte Internacional com jurisdição penal. Aguardará pela ruptura desse mundo dividido em dois eixos, simbolizado pela queda do muro de Berlim, para retomar "fôlego", que efetivamente se transformará numa idéia amplamente difundida, numa força pujante no cenário internacional, quando das atrocidades cometidas nas guerras separatistas da ex-Iugoslávia e em Ruanda ${ }^{4}$, num momento em que se havia passado mais de 50 anos do término da $2^{\mathrm{a}}$ Guerra Mundial e, nesse mesmo intervalo,

\footnotetext{
${ }^{3}$ HOBSBAWN, Eric. Era dos extremos: o breve século XX:1914-1991. 10ª Edição. Companhia das Letras, 2008, p.30.

${ }^{4}$ JAPIASSÚ, Carlos Eduardo Adriano. O Tribunal Penal Internacional: a Internacionalização do Direito Penal. Rio de Janeiro: Editora Lumen Juris, 2004, p.xvii.
} 
ocorrido pelo menos duzentos e cinqüenta conflitos armados internacionais, regionais e internos, estimando-se mais de 75 milhões mortos ${ }^{5}$, vítimas de atrocidades cujos mandantes, em geral, restam impunes.

Com a efetiva implementação do Tribunal Penal Internacional, graças à adesão ao Estatuto de Roma, criado em 1998 e ratificado por mais de 100 Estados, cria-se uma instância internacional com jurisdição sobre as pessoas responsáveis pelos crimes de maior gravidade no que tange aos direitos humanos e à dignidade da pessoa humana, antes impossível devido ao acobertamento desses criminosos pelos Estados aos quais respondiam.

O Brasil, embora tenha tardado a ratificar o Estatuto de Roma, a ele plenamente aderiu, o que o impossibilita de descumprir algum dispositivo do mesmo tratado, mesmo sob alegação de que fere preceitos constitucionais, haja vista que o Estatuto não aceita restrições por parte do Estado signatário quanto à sua adesão ao tratado, o que, sob o aspecto dos Direitos Humanos, é uma vitória. Com isso, vem se tornando cada vez mais intensificado o estudo do Estatuto de Roma por parte de juristas e autoridade públicas nacionais temerosas de que o país possa vir a ser responsabilizado internacionalmente caso descumpra algum de seus dispositivos, devido a "atritos" que possa vir a ter com a nossa Carta Magna, fato este que, se verá mais adiante, carece de fundamentos.

Foi um longo caminho trilhado pela humanidade, desde as primeiras vítimas de atrocidades perpetradas por seus semelhantes na pré-história, até as primeiras manifestações de proteção legal aos direitos mais sagrados do ser humano, ganhando corpo, inicialmente, na proteção da propriedade e representatividade da Magna Carta do Rei João Sem-Terra de $1215^{6}$, passando pelo reconhecimento de mais direitos civis na Declaração dos Direitos do Homem e do Cidadão de $1789^{7}$, do direito à uma série de

\footnotetext{
5 TAQUARY, Eneida Orbage de Britto. Tribunal Penal Internacional \& A Emenda Constitucional 45/04 (Sistema Normativo Brasileiro). Curitiba: Juruá Editora, 2008, p.13.

${ }^{6}$ http://www.middle-ages.org.uk/magna-carta.htm (acessado em 29/09/2010)

${ }^{7}$ http://pe360graus.globo.com/obj/107/77938.pdf (acessado em 29/09/2010)
} 
liberdades na Declaração do Bom Povo da Virgínia de $1776^{8}$ precedendo à Declaração de Independência dos Estados Unidos ${ }^{9}$, feita no mesmo ano, bem como às primeiras tentativas de regulamentar a guerra e os direitos dos combatentes e civis que levaram a um esboço da Cruz Vermelha em $1859^{10}$ (efetivamente reconhecida em 1909) e à Convenção de Genebra de $1864^{11}$, culminando na Declaração Universal dos Direitos do Homem de $1948^{12}$ e a Declaração Internacional dos Direitos Econômicos, Sociais e Culturais de $1966^{13}$, chegando, por fim, no Estatuto de Roma de 1998, que, como última grande manifestação internacional de proteção aos direitos da pessoa humana, culmina em assegurar a tão esperada oportunidade de se punir os mais vis perpetradores de violência contra a humanidade, ao criar uma instância capaz, por si só, de julgar esses indivíduos.

A essa instância chamamos de Tribunal Penal Internacional, foco desse trabalho como tese de dissertação para a graduação do curso de Direito pela Pontifícia Universidade Católica do Estado do Rio de Janeiro.

\footnotetext{
${ }^{8}$ http://www.rolim.com.br/2002/_pdfs/0611.pdf (acessado em 29/09/2010)

${ }^{9}$ http://www.constitution.org/usdeclar.pdf (acessado em 29/09/2010)

${ }^{10}$ http://www.ibge.gov.br/ibgeteen/datas/cruz_vermelha/comosurgiu.html (acessado em 29/09/2010)

${ }^{11}$ http://www.dhnet.org.br/educar/redeedh/anthist/gen1864.htm (acessado em 29/09/2010

${ }^{12}$ http://portal.mj.gov.br/sedh/ct/legis_intern/ddh_bib_inter_universal.htm (acessado em 29/09/2010)

${ }^{13}$ http://www.rolim.com.br/2002/_pdfs/0620.pdf (acessado em 29/09/2010)
} 


\section{Gênese da Justiça Penal Internacional: Antecedentes Históricos}

\subsection{O Surgimento da Idéia de uma Jurisdição Internacional}

Citado sempre como sendo o marco para a formação de um Tribunal Penal Internacional, o julgamento de Peter Von Hagenbach ${ }^{14}$, em 1474, na Alemanha (em um de seus vários principados na época; a Alemanha só viria a ser formada no final do século XIX), em que pese carecer das prerrogativas que fariam dele realmente ter inaugurado essa nova modalidade de jurisdição, pelos motivos que serão vistos adiante, cumpriu um papel histórico ao criar uma Corte composta por juristas de diferentes países. Von Hagenbach fora elevado ao posto de governador de Breisach pelo Duque Charles da Borgonha, tendo notoriamente instituído perseguições políticas e incitado a uma série de outros crimes praticados na cidade, tais como saques, assassinatos, estupros etc. Com a derrota do duque em batalha, Von Hagenbach, seu aliado, é preso e julgado na própria cidade de Breisach, a mando das forças vencedoras, compostas basicamente pelos Estados que faziam parte do Sacro Império Romano Germânico e de França. Von Hagenbach alegou que simplesmente cumpria ordens de seu superior (o Duque de Borgonha), tendo sido condenado a morte por crimes contra as "Leis Divinas e Humanas" "por uma Corte composta por juízes de Áustria, Suíça, Alemanha e Alsácia. Apesar de sua importância histórica, por julgar um violador dos Direitos Humanos (expressados naquela época pela vaga expressão supracitada) e não aceitar a subordinação do réu ao duque como escusa às barbaridades perpetradas, tal julgamento não pode ser tido como o primeiro exemplo de um Tribunal Penal Internacional pelo

\footnotetext{
${ }^{14}$ Bassiouni, M. Cherif. The time has come for an International Criminal Court. In: Indiana International \& Comparative Law Review. Vol.1, n¹, Spring 1991, p.1.

${ }^{15}$ JAPIASSÚ, op. cit., p.37.
} 
simples fato de que todos os juízes envolvidos pertenciam ao Sacro Império, instituindo, então, uma Corte Confederada, e não Internacional. ${ }^{16}$

Quatrocentos anos se passaram até que pudéssemos ter outra mostra daquilo que poderia vir a ser uma Corte Internacional com jurisdicionalização penal. Pouco após a tentativa de se criar a Cruz Vermelha (1859) e a criação da Convenção de Genebra (1864), horrorizado pelas barbaridades cometidas principalmente nas guerras da Criméia (18531856) e Franco-Prussiana (1870-1871), um dos criadores da Cruz Vermelha e também um dos responsáveis pela criação da primeira Convenção de Genebra, Gustave Moynier ${ }^{17}$, sugeriu junto à comunidade internacional, em 1872, a criação de um tribunal permanente que julgasse e tentasse impedir os violadores de direitos humanos e da convenção que ele ajudou a criar. Infelizmente, a proposta foi rechaçada pela maioria dos Estados nacionais ou tida como pouco realista para a época. ${ }^{18}$

\subsection{Os Direitos Humanos no pós $1^{\text {a }}$ Guerra Mundial}

A realidade, entretanto, chegou na velocidade de tanques, pondo fim ao chamado belle-époque europeu e levando incredulidade ao mundo inteiro que assistia a Europa ruir em campos de batalha marcados por trincheiras e uso de novas armas letais. E a idéia de um Tribunal Penal Internacional começa a ganhar força durante a $1^{\text {a }}$ Guerra Mundial, até começar a ganhar moldes quando do seu término, quando é criado, então, a Liga das Nações, predecessor da ONU.

Já em 1915, em plena guerra, sob a sombra das evidentes violações dos direitos humanos decorrentes do caos e atrocidades inerentes à guerra, um grupo de países aliados (Grã-Bretanha, França e Rússia), cientes das

\footnotetext{
${ }^{16}$ (2)lbid, p.38.

${ }^{17}$ http://pt.wikipedia.org/wiki/Gustave_Moynier (acessado dia 29/09/2010)

${ }^{18}$ (3) Ibid, p.38.
} 
terríveis violações comandadas por militares turcos contra civis armênios lança uma ofensiva diplomática naquilo que se tornaria palco de mais um embate por uma Corte capaz de julgar criminosos da mais nefasta espécie independentemente de sua condição política e nacionalidade.

Em 1919 é criado, então, uma comissão para investigar esse genocídio (o primeiro que se tinha notícia na entrada desse século) ocorrido no então Império Turco-Otomano, de onde chegam à conclusão de que ocorreram sérias violações de direitos humanos e que vários militares e políticos turcos deveriam ser levados à justiça. Pela primeira vez, faz-se referência ao termo "crimes contra a humanidade"19. Como entrave ao julgamento desses indivíduos o governo dos Estados Unidos alegou a não existência dos crimes pretensamente praticados por esses indivíduos na esfera internacional, daí não podendo se falar em legitimidade para um julgamento dessa forma. Para suplantar essa lacuna criou-se o Tratado de Sèvres, em 1920, que codificava as violações contra a humanidade e os crimes de guerra, recomendando o julgamento imediato dos oficiais turcos, feito por um tribunal criado pela Liga das Nações ou pelos próprios aliados. Por razões políticas o tratado não foi levado adiante e acabou sendo suplantado pelo Tratado de Lausanne, de 1924, em que visando a restaurar uma relação amistosa entre os envolvidos na $1^{\mathrm{a}}$ Guerra para com a Turquia, termina por conceder anistia aos oficiais envolvidos no primeiro massacre com intuito de exterminar um povo a que se teve notícia no século passado. $^{20}$

Contemporâneo ao incidente turco-armênio fora a tentativa de levar a julgamento o ex-mandatário do extinto Império da Alemanha, o Kaiser Guilherme II. Como parte integrante do Tratado de Versalhes, nos termos que selaram a "paz" na Europa no pós $1^{\text {a }}$ guerra, exigia-se o julgamento do Kaiser por crimes de guerra e ofensa aos tratados internacionais e a "moral

\footnotetext{
${ }^{19}$ (4)Ibid, p.39.

${ }^{20}$ BASSIOUNI,M. Cherif. Chronology of efforts to establish na International Criminal Court. In: Nouvelles Études Penales, $n^{\circ} 10$, Toulouse, Érès, 1993, p.22.
} 
internacional"; determinou-se posteriormente que o monarca seria julgado por um tribunal internacional, bem como seus aliados, oficiais e políticos alemães. Tal iniciativa serve como mais um dos exemplos do século passado de se criar a tal aguardada corte internacional com jurisdição para julgar violações de direitos humanos perpetrada por indivíduos, a mando ou não de um Estado. Decorre que o Kaiser se refugiou na Holanda, de onde veio a viver até seu falecimento, muito tempo depois; o governo do Reino da Holanda recusou-se a entregar o Kaiser para julgamento alegando que se tratavam de acusações políticas e, portanto, de vingança dos vencedores contra o ex-chefe de Estado dos derrotados. Em decorrência disso, e também por falta de vontade política dos Estados aliados, devastados pela guerra e priorizando sua recuperação a esses julgamentos, o tribunal nunca foi criado; eventualmente coube à Corte Suprema Alemã julgar seus nacionais acusados pelos crimes antes expostos. Também por falta de vontade política, dos milhares de acusados quando do término da guerra, apenas algumas dezenas deles foram de fato julgados e a maior parte destes condenados a penas brandas.

A partir desse fato, ao redor do mundo deu-se início a formação de grupos de estudos específicos nos centros acadêmicos para se efetivar num futuro não muito distante a criação da Corte internacional para julgar esses crimes, uma Corte independente e autônoma, carente de motivação política para evitar que os erros do passado não mais se repetissem. Em 1926 é sugerida na Liga das Nações a criação de uma Câmera Criminal no Tribunal Internacional de Justiça ${ }^{21}$, buscando responsabilizar os indivíduos por seus atos na esfera internacional, bem como a cooperação dos Estadosmembros no intuito de facilitarem o julgamento de seus nacionais, caso sejam acusados.

\footnotetext{
${ }^{21}$ MUELLER, Gerhard O. W.. The nomination by ISPAC to award the 1999 Nobel Peace Prize to Professor M. Cherif Bassiouni. In: ICC ratification and national implementing legislation, Toulouse: Érès, 1999, p.IX.
} 
Na mesma época, sob o ponto de vista diplomático, iniciou-se um movimento para declarar a ilicitude da guerra de agressão, ponto este estruturado no Protocolo de Genebra de 1924, que qualificou tal guerra como criminosa, sob a ótica internacional. ${ }^{22}$

Logo em seguida, em 1928, deu-se vida a um pacto importante no estudo do Direito Internacional Público, o pacto de Briand-Kellog, criado pela Liga das Nações, que exortava a renúncia à guerra como política nacional $^{23}$. Embora tenha fracassado na prática, o pacto mostrou ser um importante passo para o Direito Internacional na sua luta pelo tribunal.

No mesmo ano foi criada uma comissão frente à Liga das Nações para tratar da criação de um Tribunal Penal Internacional que julgasse os acusados de terrorismo, cuja idéia ganhou força novamente quando do assassinato do Rei Alexandre da Iugoslávia por um extremista búlgaro, em Marselha (1934). ${ }^{24}$ A Liga das Nações adotou a comissão para a criação do tribunal em 1934, que apenas contou com uma adesão, não vindo, portanto, a ser implementado. Mas as sementes já haviam sido espalhadas, e no decorrer dos anos seguintes iriam brotar, devido às atrocidades inimagináveis vividas pela humanidade nos anos da $2^{\mathrm{a}}$ Guerra Mundial.

$\mathrm{O}$ que estava sendo posto em jogo naquele momento conturbado de nossa história, segundo Valerio de Oliveira Mazzuoli era a luta pela:

“a) (...) efetivação do direito inerente a todo ser humano de vindicar a seu favor, em corte e instâncias internacionais, a proteção dos seus direitos internacionalmente consagrados, caso sejam violados, visando uma justa reparação pelos prejuízos sofridos; e b) (...) poder de punição que deve ter o Direito Internacional Público em relação àqueles crimes que afetam a humanidade como um todo, anulando por completo a dignidade inerente a qualquer ser humano., ${ }^{25}$

\footnotetext{
22 1) JAPIASSÚ, op. cit., p.41.

${ }^{23}$ http://pt.wikipedia.org/wiki/Pacto_Briand-Kellogg (acessado em 29/09/2010)

${ }^{24}$ FRAGOSO, Heleno Cláudio. Terrorismo e criminalidade política. Rio de Janeiro: UERJ (tese), 1980, p.49.

${ }^{25}$ (1) MAZZUOLI, Valerio de Oliveira. Tribunal Penal Internacional e o Direito Brasileiro. V.3. Editora Revista dos Tribunais, $2^{a}$ edição, $p 23$.
} 


\subsection{Os Tribunais Militares no pós $2^{\mathrm{a}}$ Guerra Mundial}

Se a $1^{\mathrm{a}}$ Guerra Mundial teve como pano de fundo disputas imperialistas pelas nações européias, utilizando-se em larga escala de novo material bélico, extremamente letal, a $2^{\mathrm{a}}$ Guerra Mundial logrará ser ainda mais cruel sob todos os aspectos e conceitos que possam ser apurados, porém, principalmente, no tocante a violação dos direitos humanos. A ascensão da intolerância ideológica de extrema direita e extrema esquerda no continente europeu faz ressurgir a ânsia de se efetivar a idéia de um jus puniendi em plano global, para instituir uma moderna Justiça Internacional. Segundo Mazzuoli:

"O Estado Racial em que se converteu a Alemanha Nazista no período sombrio do Holocausto - considerado o marco definitivo de desrespeito e ruptura para com a dignidade da pessoa humana, em virtude das barbáries e das atrocidades cometidas a milhares de seres humanos (principalmente contra os judeus) durante a Segunda Guerra Mundial - acabou dando ensejo aos debates envolvendo a necessidade, mais do que premente, de criação de uma instância penal internacional, com caráter permanente, capaz de processar e punir aqueles criminosos de que a humanidade quer definitivamente se livrar." 26

A estupidez humana fora levada ao extremo pelo comunismo e nazismo, onde o gigantismo dos Estados totalitários envolvidos pareceu engolir por completo as sociedades que os compunham, a ponto de doutriná-las para que seguissem as idéias do Estado sem questionamentos, como se a realidade presenciada e as idéias veiculadas fossem simplesmente "normais". O desgaste que isso provocou nessas sociedades e o desvio moral que muito dos apoiadores desses regimes sofreram foram tamanho que causaram espanto mundo afora, tamanho fora o desdém por tudo aquilo que deveria caracterizar o que há de mais sagrado na humanidade. Sob os dizeres de Eric Hobsbawn:

"Diligentes burocratas alemães, que certamente teriam achado repugnante tanger eles próprios judeus mortos de fome para abatedouros, podiam organizar os

${ }^{26}(2)$ Ibid, p.24 
horários de trem para o abastecimento regular de comboios da morte para os campos de extermínio poloneses, com menos senso de envolvimento pessoal. As maiores crueldades de nosso século foram as crueldades impessoais decididas a distância, de sistema e rotina, sobretudo quando podiam ser justificadas como lamentáveis necessidades operacionais. $" 27$

A $2^{\mathrm{a}}$ Guerra Mundial não foi pior que a $1^{\mathrm{a}}$ por conta das baixas civis ou militares, ela foi justamente pior porque terminou por "coisificar" o homem, fazendo dele uma peça, um objeto, descartável aos interesses do Estado, sem direitos; Hannah Arendt chamou isso de "banalidade do mal", ${ }^{28}$ a mortal mistura entre a capacidade destrutiva de Estados intolerantes e a burocratização da vida pública. Não é à toa que, posteriormente, não apenas nos julgamentos de Nuremberg, mas também em outros presididos pela Alemanha Ocidental, os acusados nazistas e seguidores continuarão usando como defesa o argumento de que estavam apenas acatando ordens, ou que seus trabalhos consistiam em banalidades burocráticas, não vinculadas diretamente com as acusações; felizmente, tais escusas não viriam a ser aceitas face à justiça penal internacional, que não reconhece, como veremos adiante, a isenção de responsabilidade pessoal frente ao delito, quando agindo a mando de superior (salvo quando the era exigido e não havia como descumprir), bem como a ausência de envolvimento pessoal nos crimes, que não será aceita como desculpa por não ter agido em contrário.

Pela primeira vez, como diz Alessandra Palma:

“(...) fu solo al termine della Seconda guerra mondiale, che incominciò l'emersione di beni giuridici propri della comunità internazionale, di interessi che superano $i$ confini di un singolo ordinamento statale. La comunità internazionale sentì, infatti, l'esigenza di punire i responsabili di gravi crimini commessi durante la guerra e, per la prima volta, si parlò concretamente di crimini internazionali e di responsabilità degli individui. ${ }^{29}$

\footnotetext{
${ }^{27}$ HOBSBAWN, op. cit., p.37.

${ }^{28}$ ARENDT, Hannah. Eichman em Jerusalém: um relato sobre a banalidade do mal. São Paulo: Companhia das Letras, 1999.

${ }^{29}$ PALMA, Alessandra. I crimini contro l'umanitá e Il Tribunale Penale Internazionale. Ferrara: Università Degli Studi di Ferrara, Facoltà di Giurisprudenza, 2000, p.18.
} 
Em agosto de 1945, logo após o término da guerra, foi ratificado o Acordo de Londres pelas nações vencedoras (Estados Unidos, GrãBretanha, França e URSS), que estabeleceu os moldes daquilo que viria a ser a Carta do TMI, ou Tribunal Militar Internacional, que seria encarregado de processar indivíduos vinculados ao regime nazista que cometeram crimes contra a paz, crimes de guerra e contra a humanidade.$^{30}$ Inovou nesse sentido o Tribunal ao introduzir o conceito de crimes contra a humanidade, não definido previamente em nenhuma convenção.

Estabeleceu a Carta do TMI a definição de conflito armado, bem como deixou claro a não aceitação do Tribunal, no que tange aos julgamentos, da possibilidade de defesa por parte dos réus argumentada na realização dos atos acusados em obediência aos seus superiores.

$\mathrm{O}$ esforço contínuo internacional em abominar as práticas adotadas pelos regimes perdedores da grande guerra e seus crimes contra a humanidade, embasado numa luta para trazer os mandantes à Justiça, culminou nessa Carta, que introduziu no sistema jurídico internacional os Tribunais de Nuremberg e Tóquio.

\section{3.a. O Tribunal Militar de Nuremberg}

Nos dizeres de Stefan Herbst, a introdução do Tribunal de Nuremberg significou:

“(...) uma evolución que abrió nuevos cauces al Derecho Penal Internacional y la convivencia entre los pueblos, pues esa era la primera vez que la comunidad internacional hizo el intento de llevar ante los Tribunales a criminales de guerra y responsables de crímenes contra los Derechos Humanos, y así juzgar a los acusados em um proceso justo, es decir, hacerles acreedores de la protección y la dureza de la

\footnotetext{
${ }^{30}$ MAIA, Marrielle, Tribunal Penal Internacional:Aspectos institucionais, jurisdição e princípio da complementaridade, $1^{\mathrm{a} e d i c ̧ a ̃ o, ~ E d i t o r a ~ D e l ~ R e y, 2005, p .47 ~}$
} 
justicia, sin abandonarlos em manos de la arbitrariedad de los vencedores, pero tampoco dejarlos impunes, sino exigirles responsabilidad por sus hechos ilícitos. "31

As atrocidades nazistas geraram não só uma reação no campo militar junto à comunidade internacional, como também jurídica. Nelson Hungria, em trabalho sobre o genocídio, relatou parte da sistemática nazista adotada para espalhar terror e morte:

"O exercício habitual da crueldade tornava os algozes cada vez mais insensíveis. Mais discretas que os fuzilamentos, inventaram-se as câmaras de gás, onde as vítimas eram metidas de cambulhada, para respirarem a morte. Os mal-adestrados executores desse monstruoso processo de extermínio não sabiam, a princípio regular o escapamento de gases deletérios, e um médico oficial informava, em relatório, com resquícios de escrúpulos:

"Em geral, a aplicação dos gases não é feita segundo a regra. Atabalhoadamente, os encarregados da tarefa comprimem o fundo do acelerador, e o resultado é que as pessoas morrem por asfixia e não em estado de sono, como fora previsto. Verificou-se agora que, cumpridas as minhas instruções, isto é, manobrando-se corretamente as alavancas, os prisioneiros adormecem suavemente e a morte sobrevém com mais rapidez. Já não se encontram, como anteriormente, fisionomias convulsas, nem excreções. "32

O ódio nazista não poupava nenhum "indesejado" ao seu alcance; em que pese ter sido pior a perseguição aos judeus, suas atrocidades atingiram as mais variadas etnias e os mais variados grupos político-ideológicos e sociais. O que Hitler almejou, entre outros objetivos, foi eliminar da face da terra seus opositores e todos aqueles que não pertenciam ao seu modelo idealizado de sociedade; nunca, em toda a história da humanidade, ocorreu algo semelhante: uma meta de governo nitidamente direcionada a perseguir e exterminar todos os indivíduos não condizentes com um determinado perfil idealizado pelo Estado. A matança de judeus, nos dizeres de Himmler, não passava de um "expurgo de piolhos 33 ", sendo que "destruir piolhos não é uma questão de ideologia, mas uma questão de limpeza”.

\footnotetext{
${ }^{31}$ Herbst, S.: Los derechos humanos ante las cortes: los juicios de Nuremberg y su significado actual. Revista Memória, Nuremberg, n.8,p. 12-20, 1996

${ }^{32}$ HUNGRIA, Nelson. Genocídio. In: Comentários ao Código Penal. Volume VI, $4^{\mathrm{a} e d}$., Rio de Janeiro: Forense, 1958, p.367/368.
}

${ }^{33}$ http://www.uff.br/pgcp/page0/files/nelsongasparinjr.pdf (acessado em 04/10/2010) 
Hitler, ao falar da Polônia ocupada, disse que: "Na Polônia, o estado de coisas ficou inteiramente definido. Como os judeus não quisessem trabalhar, foram mortos. Se não podiam trabalhar, deviam morrer. Tinham de ser tratados como bacilos de tuberculose. Nada tem isto de cruel, pois é sabido que mesmo as criaturas mansas da natureza, como as corças e os gamos, devem ser mortos para que não possam fazer estragos. ${ }^{34,}$

Entre tantos outros relatos, ficam evidentes não só as enormes atrocidades cometidas por membros do nazismo, mas também que isso fazia parte da política estatal alemã; e enquanto a Alemanha produzia algumas das mais sórdidas violações aos direitos humanos, tais violações eram questionadas judicialmente pelos Aliados (ex.: Declaração de Saint James de 1942 e a Declaração de Moscou de $1943^{35}$ ), cujos questionamentos adquiriram maior força política com a criação da Comissão de Crimes de Guerra das Nações Unidas em 1943 (embora pareça fazer referência à ONU, na verdade refere-se aos países aliados na Segunda Guerra Mundial). Naquela época, como anteriormente se vira na Primeira Grande Guerra e antes, o problema era exatamente o de se adequar os mecanismos jurisdicionais para uma realidade na qual ainda não se havia definido e sancionado, pelo direito internacional, determinadas condutas as quais se queriam ver punidas.

Com o término da guerra, foram acordadas entre as partes vencedoras, através da Conferência de Londres, as regras que iriam orientar o processo e julgamento dos criminosos de guerra do Eixo; dessa conferência nasceu a Carta do Tribunal Internacional Militar, hoje conhecido como Tribunal de Nuremberg.

Os Aliados exerceram, através do Allied Control Council Law n.10 (CCL10), um controle judicial sobre a Alemanha derrotada, permitindo a

\footnotetext{
${ }^{34}$ HUNGRIA, op. cit., p. 369

${ }^{35}$ JAPIASSÚ, op. cit., p.47.

${ }^{36}$ http://avalon.law.yale.edu/imt/imt10.asp (acessado em 04/10/2010)
} 
juízes aliados julgarem alemães tidos por criminosos de guerra dentro da própria Alemanha. Dos 24 indiciados pelo Tribunal de Nuremberg, 22 foram processados, sendo posteriormente presos; daqueles que foram encarcerados, 12 foram condenados à morte, 3 à prisão perpétua e os demais sentenciados a penas entre 10 e $12 \operatorname{anos}^{37}$. Goering, segundo da hierarquia nazista, suicidou-se no final do julgamento. Nenhum militar aliado foi julgado pelo tribunal, o que reforçou a alegação dos julgados de que se tratava de um tribunal político, dos vencedores. Quanto aos criminosos de guerra não-alemães, ficaram eles sujeitos a tratados de rendição que previam a extradição de criminosos de guerra, não podendo o CCL10 ter sido utilizado ${ }^{38}$; nenhum criminoso de guerra italiano foi julgado, por exemplo.

Curiosidade a parte, em que pese o termo "militar", todos os juízes membros do Tribunal, salvo o soviético, eram civis; a adesão deste termo à nomenclatura do Tribunal deve-se ao direito dos Estados Unidos, que encontrava empecilhos para a imposição deste tribunal pelo seu direito penal (princípio da anterioridade), mas não pelo seu direito penal militar. A cidade de Nuremberg foi escolhida para sediar os julgamentos porque fora naquela cidade que ocorreram as mais grandiosas mobilizações populares do nazismo, bem como o fato de ter sido ali a sede da implementação das leis de perseguição racial.

Aos acusados imputaram-se as práticas de conspiração ${ }^{39}$, crimes contra a paz, crimes de guerra e crimes contra a humanidade.

\footnotetext{
${ }^{37}$ GOLDSTONE, R.: Cincuenta años despues de Nuremberg: um nuevo tribunal penal internacional para crimines que atentam contra los derechos humanos. Revista Memoria, Nuremberg, n.8,p.4-11,1996.

${ }^{38}$ MAIA, Marrielle, op. cit.,p.49

${ }^{39}$ CARLOS, Canêdo. O genocídio como crime internacional. Belo Horizonte: Del Rey, 1999, p.68. De acordo com o autor, o crime de conspiração, inexistente na construção jurídica européia continental, de origem anglo-saxã, significaria um acordo de vontades para um plano preconcebido. Na legislação brasileira, aquilo que mais parecido poder-se-ia citar seria o crime de quadrilha.
} 
Com relação ao crime de conspiração, o Tribunal de Nuremberg inovou, no sentido de, contrariamente ao direito continental europeu (que exigia a existência de um crime efetivamente praticado para ser configurado), ter ele reconhecido a conspiração como crime por si só, isto é, sem a necessidade da existência de um outro crime que o justificasse. ${ }^{40}$

Com relação ao crime de paz, enfatiza-se que a guerra de agressão já havia sido considerada como ilícito pela comunidade internacional, através do chamado Pacto de Briand-Kellog. A política exterior de Hitler desencadeou uma onda de agressões a outras nações que teriam sido vistas pelo Tribunal como violações a uma série de tratados e documentos internacionais, como o Protocolo de Genebra de 1924, o Tratado de nãoagressão entre Alemanha e URSS de 1939, dentre outros.

Ao contrário dos demais crimes imputados aos réus, o crime de guerra, quando da implementação do Tribunal, há muito havia sido tido como proibitivo internacional (desde antes das Convenções de Haia e das Convenções de Genebra, do final do século XIX e começo do século XX); a diferença é que essas convenções não lograram fazer o que o Tribunal fez, que foi o de reconhecer o papel do indivíduo nas violações dos direitos humanos e nos crimes de guerra, antes cabível exclusivamente ao Estado, como único responsável.

No campo da formação teórica, coube ao Tribunal de Nuremberg estabelecer uma noção clara do chamado crime contra a humanidade, que até então carecia de conceito. Isto, dentre outros fatores, foi utilizado como crítica ao Tribunal, que inovou em vários aspectos jurídicos, mas também pôs em dúvida se não estaria violando alguns preceitos para poder pôr em prática os julgamentos; entre as críticas, a principal referia-se a uma possível violação da reserva legal, por não existir, quando dos julgamentos, uma definição legal para uma série de atos pelos quais estavam sendo julgados os réus. Outras críticas referiam-se a impossibilidade de o direito

\footnotetext{
${ }^{40}$ (1)JAPIASSÚ, op. cit. , p.54.
} 
penal atuar sobre os chamados "atos de Estado", a impossibilidade de reconhecimento de responsabilidade penal de entes coletivos, impossibilidade de atuação do direito penal internacional contra os indivíduos e a referência à obediência hierárquica como escusa dos atos cometidos.

No tocante aos crimes de guerra, entenderam os juízes que não houve violação do princípio da anterioridade, pois o estatuto declarara o que fora convencionado em Haia, em 1907, nos artigos 46, 50 e 56. Com relação aos crimes contra a paz, entenderam os juízes que o princípio da reserva legal não limita a soberania dos Estados (assim encontra-se a justificativa para punir aqueles que, sem prévio aviso, desrespeitam tratados solenes e agridem outros Estados). Frisou-se aos acusados que estes estavam plenamente a par dos tratados ratificados pela Alemanha antes da guerra, e que por isso, deveriam ter agido no sentido de respeitá-los.

O princípio da irretroatividade, entretanto, foi violado. ${ }^{41}$ Embora tenha de fato ocorrido a violação, a doutrina majoritária afirma que a violação dessa garantia aos réus não seria por si só suficiente para anular o julgamento, posto que havia junto à sociedade internacional um anseio moral para que fossem os réus de fato levados a julgamento. O direito penal internacional, mesmo sendo uma disciplina autônoma, não pode deixar de lado as garantias fundamentais elencadas no direito penal, o que terminou deixando, por assim dizer, um pouco "arranhada" a imagem do Tribunal de Nuremberg.

O Tribunal inovou ao tipificar os chamados crimes contra a humanidade; inovou, também, ao reconhecer um direito acima dos Estados e da própria positivação do direito. Porém, pecou ao ferir o princípio da reserva legal, levando a julgamento os réus por lei posterior aos fatos. Nos dizeres de Nelson Hungria: ${ }^{42}$

\footnotetext{
${ }^{41}$ HUET, André; KOERING-JOULIN, Renné. Droit Pénal International. Paris: PUF, 1994, p.57

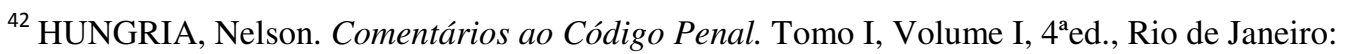
Forense, 1958,p.31
} 
"O Tribunal de Nuremberg há de ficar como uma nódoa da civilização contemporânea: fez tabula rasa do nullum crimen nulla poena sine lege (com um improvisado Plano de julgamento, de efeito retroativo, incriminou fatos pretéritos e impôs aos seus autores o "enforcamento" e penas arbitrárias); desatendeu ao princípio da 'territorialidade da lei penal'; estabeleceu a responsabilidade penal de indivíduos participantes de tais ou quais associações, ainda que alheios aos fatos a eles imputados, funcionou em nome dos vencedores, que haviam os mesmíssimos fatos atribuídos aos réus; suas sentenças eram inapeláveis, ainda quando decretavam a pena de morte. Como diz Montero Schmidt (Ver. De Ciencias Penales, tomo IX, $n^{\circ} 4 m$ 1946): “jamás había podido concebir la mente de jurista alguno um derumbe más grande de los princípios de Derecho, que se ilumino, al postre, com uma escerna grotesca: el ahorcamiento Del cadáver del Mariscal Goering, después que este se había suicidado!”

Sem maiores constatações poder-se-ia seguramente afirmar que se tratou de um tribunal dos vencedores sobre os vencidos, embora, nas circunstâncias que propiciaram sua criação, não se pudesse esperar outro caminho a seguir senão o que de fato ocorreu. O Tribunal de Nuremberg, em que pese o seu alto teor político sobre os fatos, passando por cima de algumas valiosas garantias legais, serviu como exemplo de um tribunal internacional, servindo como base para a posterior criação do Tribunal Penal Internacional. Nele, forjado pela repulsa ao nazismo e a tudo o que ele significa, reconheceu-se o conceito de crimes contra a humanidade e tipificou-se os de crimes de agressão e de guerra ${ }^{43}$; também reconheceu o indivíduo como detentor de direitos e obrigações na esfera internacional, como sujeito no direito penal internacional. Também tem mérito o Tribunal por não ter cedido à tentação de dramatizar o julgamento, mantendo os juízes uma linha coesa e séria que acabaram por contribuir com a justiça internacional.

\section{3.b. Tribunal Militar Internacional para o Extremo Oriente}

No período pós-guerra também surgiu outra comissão investigativa, dessa vez criada em Moscou e encabeçada pela União Soviética. A idéia nasceu numa conferência em Cairo, em 1943, chefiada pelos aliados e mais

\footnotetext{
${ }^{43}$ JAPIASSÚ, op. cit. , p.59.
} 
a presença da China, dentre outros Estados; teve como objetivo repudiar os atos de agressão cometidos pelo Império do Japão a inúmeros países e colônia européias no Pacífico e levar à justiça os responsáveis pelas atrocidades cometidas pelo exército japonês nos territórios ocupados, já que se tinham informações de uma enorme quantidade de violações aos direitos humanos perpetrados pelo mesmo a populações civis, em especial à chinesa, que sofreu com a ocupação de extensa porção de seu território.

Assim como a Alemanha nazista, o Império do Japão entrou na guerra possuindo um histórico de adesões a tratados de paz no início do século XX, tais como o da Conferência de Haia de 1907; então havia uma pressão de punir estes Estados não só pelas violações aos direitos humanos, mas as inegáveis violações por parte desses Estados aos tratados de paz firmados.

A Comissão de Crimes das Nações Unidas recomenda, logo no final da guerra, que fosse estabelecido um Tribunal de crimes de guerra para julgar os criminosos japoneses; tal proposta é reiterada na Comissão de Moscou, também em 1945, pelas nações aliadas, mais China, Austrália, Nova Zelândia e Holanda. Decide-se, então, que o Tribunal terá Tóquio como sua sede, sendo devidamente instituído em janeiro de $1946 .{ }^{44}$

A Corte foi formada por 11 juízes, provenientes dos países aliados, mais a presença holandesa, chinesa, australiana, neo-zelandesa, canadense, filipina e indiana (a Índia fora convocada a participar dos julgamentos na condição de país neutro no conflito e importante Estado asiático); teve como fundamentação o Acordo de Londres, ou seja, aquele que instituiu as bases para o Tribunal de Nuremberg também o fez para o Tribunal de Tóquio. $^{45}$

\footnotetext{
${ }^{44}$ http://pt.wikipedia.org/wiki/Tribunal_Militar_Internacional_para_o_Extremo_Oriente (acessado em 05/10/2010)

${ }^{45}$ ARAUJO, Jr., João Marcello. Tribunal penal permanente, instrumento de garantia dos direitos fundamentais (processo legislativo histórico e características). Parecer apresentado ao Instituto dos Advogados Brasileiros, indicação n036/98, Rio de Janeiro, 1999
} 
O Tribunal Militar de Tóquio funcionou entre 1946 e 1948, julgando os criminosos de guerra japoneses pelos mesmos motivos dados aos nazistas (crimes de guerra, crimes contra a paz, crimes contra a humanidade), excetuando o crime de conspiração, a fim de evitar problemas de interpretação durante o julgamento. ${ }^{46}$

Vinte e oito indivíduos, dentre civis e militares, foram levados a julgamentos em Tóquio; ao contrário de Nuremberg, nenhum deles foi inocentado. Dos mais de 80 prisioneiros de guerra destinados inicialmente ao julgamento, a maioria, composta por empresários e civis, nem chegou a ser indiciada. Novamente, a política prevalecia sobre a justiça; numa época em que os planos de reconstrução da Europa e Japão estavam sendo postos em andamento, a presença de empresários importantes, todos anticomunistas, no cenário japonês, favoreceria a consolidação do país como potência regional e importante aliado dos Estados Unidos, contra o perigo da dominação comunista sobre China e Coréia então divididas por uma guerra civil. Uma grande leva de prisioneiros de guerra japoneses foi libertada pelos aliados, reinserindo-se na sociedade japonesa, sem sequer passar por um processo. O Imperador Hirohito, em que pese seu papel fundamental nos conflitos bélicos japoneses da Segunda Guerra Mundial, assim como o Kaiser Guilherme II na Primeira Guerra Mundial, não foi levado a julgamento; seu papel político no Estado japonês e sua importância como símbolo vivo para a sociedade japonesa (até hoje a figura do monarca, em que pese não exercer mais nenhum papel político, é extremamente importante na cultura japonesa) prevaleceu, permanecendo o Imperador no poder até a sua morte, em $1989^{47}$.

Assim como o Tribunal de Nuremberg, o Tribunal de Tóquio pode ser traduzido como um tribunal de vencedores, onde os perdedores não exerceram mais que seu papel predestinado como perdedores no jogo

\footnotetext{
${ }^{46}$ JAPIASSÚ, op.cit. p.63

${ }^{47}$ http://pt.wikipedia.org/wiki/Hirohito (acessado em 05/10/2010)
} 
político do final da guerra. Em que pese ter havido outros julgamentos no período pós-guerra, sem sombra de dúvida foram esses dois tribunais os mais importantes sob inúmeros aspectos, dentre eles, o que interessa para a futura formação do Tribunal Penal Internacional, a inserção de determinados preceitos (como o julgamento dos réus independentemente de sua nacionalidade, seu status na sociedade em que vivia e seu papel político, a idéia de responsabilidade penal internacional coletiva e individual, o fortalecimento da noção de direitos humanos e da proteção supra-estatal desses direitos, dentre outros). Assim como no Tribunal de Nuremberg, no Tribunal de Tóquio os réus tiveram violados os seus direitos no que tange a determinados princípios, em especial o da reserva legal. Também é importante ressaltar que, tanto no tribunal europeu quanto no asiático, os Aliados não foram chamados para responder as atrocidades que, por sua vez, cometeram nos territórios do Eixo; é difícil tirar conclusões no cenário de caos que foi a Europa e nos anos daquela guerra, saber qual foi, por exemplo, o país mais vitimado, mas é certo que a Alemanha sofreu mais bombardeios no final da guerra do que lançou sobre outros países durante todo o conflito; do Japão, nenhum outro país teve, desde então, o horror de presenciar um ataque com bombas nucleares direcionados a populações civis. Ninguém até hoje respondeu por essas atrocidades, o que representa uma mancha na justiça penal internacional.

\subsection{Os Tribunais ad hoc e o papel do Conselho de Segurança da ONU}

\section{4.a O Tribunal ad hoc para a antiga lugoslávia}

Os Balcãs, região que delimita os já extintos Reino da Iugoslávia e, posteriormente, República Socialista Federal da Iugoslávia, sempre foi uma região marcada por conflitos étnicos. Nessa extensa área convivem croatas, sérvios, albaneses, macedônios, turcos, húngaros, eslovenos, kosovares, montenegrinos, dentre outros povos; a região também divide-se por idiomas 
(tão diversos quanto seus povos), por religião (majoritariamente dividida entre católicos, muçulmanos e cristãos ortodoxos), alfabeto (romano, grego, cirílico e até o começo do século XX, arábico) e costumes, num caldeirão multiétnico que não se entende desde os tempos da Roma imperial. ${ }^{48}$

No cenário confuso que eram os Bálcãs no começo dos anos 90, os Estados recém independentes lançam uma campanha na imprensa internacional para que noticiem as violações de direitos humanos perpetrados pelo governo sérvio na Bósnia. As acusações fazem efeito e em 1993 o Conselho de Segurança da ONU cria o Tribunal Internacional para a ex-Iugoslávia, com intuito de julgar os crimes cometidos contra a humanidade nos territórios recém desmembrados da Iugoslávia, a partir de 1991.

Os conflitos persistem com sistemáticas limpezas étnicas produzidas por ambos os lados (sérvios de um lados, croatas e bósnios no outro) até que em 1995, no Acordo de Dayton ${ }^{49}$, estabelecem-se as bases para a repartição geográfica da extinta Iugoslávia, assegurando uma relativa paz na região; a paz cessa em 1999, quando albaneses residindo em Kosovo, província milenarmente tida como pertencente ao povo sérvio, declaram sua independência, resultando em imediato ataque sérvio à região, produzindo uma nova leva de exilados e violações aos direitos humanos. Desta vez a resposta pela comunidade internacional é mais enérgica, a OTAN bombardeia a Sérvia, que concorda num cessar fogo, enquanto a ONU passa a administrar o Kosovo, que será um Estado independente a partir de 2008. O presidente sérvio, Slobodan Milosevic, bem como importantes figuras dos governos sérvio e bósnio, principalmente, serão levados a julgamento pelo Tribunal ad hoc da ex-Iugoslávia em 2001 (Milosevic não será reeleito em 2000; sua ida à ICTY será motivada por pressões políticas dentro da Sérvia, já que o governo agora era comandado pela oposição),

\footnotetext{
${ }^{48}$ http://www.mundovestibular.com.br/articles/6515/1/Conflitos-nos-

Balcas/Paacutegina1.html (acessado em 05/10/2010)

${ }^{49}$ http://www.dw-world.de/dw/article/0,,332295,00.html (acessado em 05/10/2010)
} 
região essa que ainda presencia focos de conflito apenas adormecidos, hoje em dia; Milosevic morrerá encarcerado em 2006.

Sobre os ocorridos, o Conselho de Segurança afirmou:

“(...) A julgar pelo grande número de informações nas quais foram descritas as políticas e práticas aplicadas na Ex-Iugoslávia, a "depuração étnica" se produz mediante homicídios, torturas, encarceramentos arbitrários, execuções sem processo judicial, estupros e outras agressões sexuais, confinamento de populações civis em guetos, expulsão pela força, deslocamento e deportação de populações civis, ataques deliberados ou ameaças de ataque contra civis e zonas civis, destruição injustificada de bens. Estas práticas constituem crimes de "lesa-humanidade" e podem ser assemelhadas a crimes de guerra concretos. Esses atos também poderão ser considerados como compreendidos na Convenção de Prevenção e Repressão do Delito de Genocídio. ${ }^{50}$

No que se refere ao ódio racial como principal propulsor dos conflitos naquilo que se considera como a Guerra dos Bálcãs, João Marcello de Araújo Jr. elucida:

"A vinculação entre as agressões sexuais e a política de depuração étnica ficou provada de forma manifesta, pois muitos estupros foram praticados em praça pública com o fim de desmoralização pessoal e coletiva e, além disso, os estupradores afirmavam que queriam tornar suas vítimas grávidas e, quando efetivamente engravidavam eram mantidas presas pelo tempo necessário a tornar inviável o aborto. Ficou conhecido o caso de uma mulher muçulmana, que permaneceu detida por um vizinho, durante seis meses, em uma casa perto de sua aldeia. Foi estuprada reiteradas vezes por três ou quatro soldados, que lhe diziam que daria à luz um menino chetnik, que ao crescer mataria muitos muçulmanos.

(...)

Grande parte dos atentados aconteceram no contexto dos esforços efetuados para o deslocamento de grupos étnicos de um lugar para outro. Além disso, alguns dos supostos autores alegaram haver recebido ordens para a prática de estupros." ${ }^{, 51}$

Sendo o foco desta monografia o Tribunal Penal Internacional, a referência aos tribunais $a d$ hoc e dos tribunais militares internacionais da Segunda Guerra Mundial, bem como o de outros tribunais ao longo da história faz-se necessário tão somente para mostrar a lenta evolução do direito penal internacional, e das conquistas adquiridas, passo a passo, por cada um desses tribunais, por cada uma dessas situações.

\footnotetext{
${ }^{50}$ Documento S/25374 ONU, parágrafos 56 e 57.

${ }^{51}$ ARAÚJO JR., João Marcelo, op. cit., p.62
} 
O Tribunal ad hoc para a ex-Iugoslávia, ou ICTY, foi estabelecido em 1993 (o Conselho de Segurança da ONU, em 22/02/1993, criou, pela Resolução $827^{52}$, “(...) um tribunal internacional para julgar as pessoas presumidamente responsáveis por violações graves ao Direito Internacional Humanitário, cometidas no território da ex-Iugoslávia a partir de 1991"), com sede em Haia, na Holanda, tendo como objetivo processar e julgar as graves violações de direitos humanos cometidas por alguns integrantes fundamentais nos conflitos separatistas e étnicos ocorridos nos Bálcãs dos anos 90. Entre os crimes pelos quais foram julgados encontram-se os de violações às Convenções de Genebra, genocídio e crimes contra a humanidade.

O Tribunal ad hoc para a ex-Iugoslávia, diferentemente dos tribunais de Nuremberg e Tóquio, servirá para julgar apenas os indivíduos ${ }^{53}$, reforçando a idéia de responsabilidade pessoal no cenário internacional. Além disso, o Tribunal ad hoc inicia sua jurisdição de forma concorrente aos demais tribunais, o que quer dizer que o ICTY poderia assumir qualquer caso, a qualquer momento e andamento do processo, envolvendo réus relacionados à Guerra dos Bálcãs, podendo desde já assumir a investigação concernente ao caso em foco e as rédeas do processo, desde que comprove seu interesse em assumir o julgamento.

Todos os juízes do ICTY precisam ser aprovados pela ONU, para um mandato de 4 anos, com direito à reeleição. Diferentemente dos Tribunais de Tóquio e Nuremberg, no ICTY os réus têm direito a recorrer das decisões tomadas pelos juízes (originalmente 11, hoje são 25 a julgar no ICTY, devido ao aumento do número de processos desde sua criação, havendo uma procura maior das vítimas ao Tribunal). O Tribunal também está impossibilitado de punir com a morte aos condenados, que somente

\footnotetext{
${ }^{52}$ http://www.artigos.com/artigos/sociais/direito/o-tribunal-penal-internacional-e--ojulgamento-dos-horrores-de-slodoban-milosevic-12004/artigo/ (acessado em 05/10/2010) ${ }^{53}$ JAPIASSÚ, op. cit., p.97
} 
podem ser acusados pelo Tribunal estando presentes (não cabe julgamento in absentia); durante o julgamento, os réus são mantidos presos em Haia.

Os acusados em geral, seguindo a mesma linha dos acusados alemães e japoneses, basearam sua defesa na tentativa de deslegitimar o tribunal, afirmando, dentre outras:

a) Que o tribunal fora estabelecido ilegalmente por ter sido criado pelo Conselho de Segurança da ONU e não por um tratado internacional;

b) Que o ICTY não poderia ter primazia para julgar sobre as Cortes nacionais envolvidas na guerra;

c) Que o ICTY não teria competência para julgar porque se legitimava como Corte para julgar os responsáveis por conflitos armados internacionais, o que não teria ocorrido na Iugoslávia, se tratando, então, de um conflito doméstico.

As alegações impetradas pelos réus serviriam como base para o avanço da justiça penal internacional, ajudando a legitimar o ICTY. Este, em resposta à defesa da maioria dos réus, afirmou que este tribunal se legitimava pelo Conselho de Segurança, a quem cabe zelar pela manutenção da paz no mundo; a criação dos tribunais ad hoc pela ONU certamente possui legitimidade jurídica, mas suas características correspondem à natureza e circunstâncias das situações que geraram seu estabelecimento, o que torna patente o vazio jurídico decorrente da inexistência (até então) de uma instância internacional permanente e independente, com base em um instrumento de escopo universal, capaz de julgar os responsáveis pelos crimes mais graves de interesse internacional. O estabelecimento do ICTY estaria legitimado, portanto, pelo art. 41 da Carta das Nações Unidas ${ }^{54}$; os

\footnotetext{
${ }^{54}$ Art. 41 da Carta da ONU: "O Conselho de Segurança decidirá sobre as medidas que, sem envolver o emprego de forças armadas, deverão ser tomadas para tornar efetivas suas decisões e poderá convidar os Membros das Nações Unidas a aplicarem tais medidas. Estas poderão incluir a interrupção completa ou parcial das relações econômicas, dos meios de comunicação ferroviários, marítimos, aéreos, postais, telegráficos, radiofônicos, ou de outra qualquer espécie
} 
atos praticados pelo tribunal foram endossados pela ONU, no seu parlamento (a Assembléia Geral da ONU). Quando questionada, com relação ao art.14. $\$ 1^{\circ}$ do Pacto Internacional de Direitos Civis e Políticos ${ }^{55}$, considerou-se que o ICTY "foi criado por lei, de acordo com as regras do direito e, mais do que isso, estavam asseguradas todas as condições para um julgamento justo, tanto no se artigo 21 do Estatuto do ICTY $^{56}$, como nas Regras de Processo e Prova"57.

O ICTY assumiu caráter de primazia sobre os tribunais nacionais envolvidos no conflito pela simples razão de que a cooperação jurídica internacional, algo sempre complicado, torna-se mais difícil ainda de ocorrer quando envolve países com relações conflituosas; seria também um tribunal mais prático e célere para julgar os criminosos de guerra do que os tribunais nacionais, que, naquela época, devido às tensões resultantes da guerra, ainda recente na memória dos nacionais, poderiam comprometer o julgamento. Apesar dos argumentos fortes para a imposição da primazia do ICTY, infelizmente, alguns anos depois, na convenção que formulou o

e o rompimento das relações diplomáticas." http://www.onu-brasil.org.br/doc4.php (acessado em 05/10/2010)

${ }^{55}$ Todas as pessoas são iguais perante os Tribunais e as Cortes de Justiça. Toda pessoa terá o direito de ser ouvida publicamente e com as devidas garantias por um Tribunal competente, independente e imparcial, estabelecido por lei , na apuração de qualquer acusação de caráter penal formulada contra ela ou na determinação de seus direitos e obrigações de caráter civil. A imprensa e o público poderão ser excluídos de parte ou da totalidade de um julgamento, quer por motivo de moral pública, ordem pública ou de segurança nacional em uma sociedade democrática, quer quando o interesse da vida privada das partes o exija, quer na medida em que isto seja estritamente necessário na opinião da justiça, em circunstâncias específicas, nas quais a publicidade venha a prejudicar os interesses da justiça; entretanto, qualquer sentença proferida em matéria penal ou civil deverá tornar-se pública, a menos que o interesse de menores exija procedimento oposto, ou o processo diga respeito a controvérsias matrimoniais ou à tutela de menores.

http://www.article19.org/work/regions/latin-america/FOI/pdf/onu-pacto_inter.dir.civ.pol.pdf (acessado em 05/10/2010; grifos meus na transcrição)

${ }^{56}$ http://www.icty.org/x/file/Legal\%20Library/Statute/statute_sept09_en.pdf

http://www.icty.org/sid/135 (acessados em 05/10/2010)

${ }^{57}$ JAPIASSÚ, op.cit., p.102 
Tratado de Roma, prevaleceu a tese da complementaridade do TPI, ao invés de sua primazia sobre as demais cortes.

Com relação à alegação de ter se tratado de um conflito interno e não nacional, alguns pontos devem ser frisados. Primeiramente, o ICTY afirmou ter competência para julgar num espaço geográfico onde hajam conflitos, sejam eles de guerra no sentido geral do termo, ou de guerrilha e investidas. Afirmou também que o ocorrido na Iugoslávia tinha características de conflito internacional e interno ao mesmo tempo, dando legitimidade ao tribunal para julgar os envolvidos na guerra.

No final das contas, a criação do ICTY foi uma questão bastante controversa. Como os tribunais militares de Nuremberg e Tóquio, sua criação foi determinada por um órgão político e não por um tratado multilateral. Contudo, o Tribunal reafirmou a responsabilidade penal individual por violações ao direito internacional humanitário e contribuiu para o processo de construção de um ordenamento jurídico internacional, como a ampliação a certas violações (por ex. o estupro, considerado entre os crimes contra a humanidade).

\section{4.b O Tribunal ad hoc para Ruanda}

Ruanda é um país de dimensões pequenas, no leste do continente africano (ou centro-oriental), fazendo fronteira com Uganda, Tanzânia, Burundi e República Democrática do Congo (RDC). Sua história é marcada por conflitos entre as duas principais etnias, os hutus (aproximadamente 4/5 da população, tendo originalmente chegado a região a cerca de 1500 anos atrás) e os tutsis (chegaram à região no século XV d.C.), desde muito antes da independência da Bélgica, em 1962. ${ }^{58}$ Sua economia basicamente consiste em subsistência e turismo, devido à exuberante vida selvagem, lar de numerosa população de gorilas selvagens. O país é considerado hoje um

\footnotetext{
${ }^{58}$ http://pt.wikipedia.org/wiki/Ruanda (acessado em 09/10/2010)
} 
modelo a ser seguido no continente africano, em termos de política (em 2008 tornou-se o primeiro país no mundo a eleger um parlamento predominantemente feminino, em eleições tidas pela comunidade internacional como limpas), economia (a população teve sua renda triplicada na última década, tendo se tornado o $44^{\circ}$ membro da Commonwealth e segunda país do grupo a não pertencer a um passado de colonização britânica), urbanização (a capital, Kigali, é tida como a capital mais limpa e preservada do continente, tendo seu modelo de urbanização começado a ser implementado no resto do país). Embora os desafios ao país ainda sejam vastos, e a promessa de desenvolvimento ainda sejam sobrepujadas pelo baixo índice de desenvolvimento humano, o país nunca despertou interesse internacional, até 1994, quando ocorreu aquilo que se considera como o último genocídio do século $\mathrm{XX}$, terminando com um saldo de 800.000 mortos, em sua maioria tutsis, num extermínio de aproximadamente um décimo da população, na época. As estimativas não são exatas, não tendo o Tribunal ad hoc, posteriormente, certeza quanto ao número de vítimas:

"Le Tribunal lui-même considere que lês estimations du nombres total dês victimes varieraient entre 500.000 et 1 million ou plu'sur une population totale de 8 millions d'habitant et, em 3 moins, d'avril à juillet 1994." ${ }^{, 59}$

O processo de democratização do país, que vinha tomando forma nos anos 70 e 80, foi subitamente paralisado quando, em 1994, sob circunstâncias até hoje não esclarecidas, o avião presidencial, transportando os presidentes de Ruanda (Juvénal Habyarimana) e Burundi (Cyprien Ntaryamira), foi abatido em espaço aéreo ruandense (em 06/04/1994). Poucas horas depois do atentado assumiam o poder do país as milícias extremistas hutus (Interahamwe) e a guarda presidencial, que cercaram a cidade, dificultando a fuga dos residentes ou o auxílio de estrangeiros;

\footnotetext{
${ }^{59}$ LANGHMANI, Slim. Le tribunal Pénal International pour Le Rwanda. In: Justice et jurisdictions internationales. Paris: Pedone, 2000
} 
como primeiro ato pós-atentado, o governo interino decretou a prisão de milhares de tutsis e dissidentes hutus. De prisão o cenário se converteu em massacre, onde a população de maioria hutu, majoritariamente descontente em ter que conviver com tutsis como seus vizinhos e ansiosos por um governo que os expulsasse da política ou até do país, insuflados por mensagens de ódio transmitidas via televisão, rádio ou nas ruas, pegaram em armas (quase todas "brancas", isto é, sem emprego de fogo produzido por pólvora, como machetes e facões). A notícia de um massacre ocorrendo na capital Kigali correu o mundo, e chegou à milícia de oposição tutsi (historicamente minoritário, porém favorecida pelos governos anteriores, transformando-se numa facção melhor equipada que a milícia hutu), fora da cidade, que iniciou a ofensiva, agravando a quantidade de vítimas do conflito.

Em 23 de junho do mesmo ano, a ONU resolve, por iniciativa do Conselho de Segurança, enviar uma força de paz à capital (2.500 soldados franceses e belgas) e ao sudoeste do país. Uma semana depois, a Comissão de Direitos Humanos da ONU publica um relatório sobre o genocídio em Ruanda, estabelecendo em 800.000 o número de vítimas. No dia 4 de julho de 1994, a milícia tutsi, que já havia tomado praticamente todo o país, conquista Kigali, pondo fim ao conflito armado com a milícia hutu, que concorda com um cessar-fogo. O chefe da FRP (Frente Patriótica Ruandesa, a milícia tutsi), Paul Kagame, é empossado como vice-presidente, mantendo uma relação conflituosa com o presidente (Pasteur Bizimungu), que renuncia ao cargo em 2000, deixando Kagame na presidência, sendo oficialmente eleito em 2003 em eleições democráticas assistidas pela imprensa internacional (Kagame permanece no cargo até hoje).

O Conselho de Segurança, levando em consideração o relatório produzido pela Comissão de Direitos Humanos (Resolução 955/1994) ${ }^{60}$,

\footnotetext{
${ }^{60}$ http://www.usp.br/jorusp/arquivo/2008/jusp822/pag03.htm (acessado em 09/10/2010)
} 
aprova a criação do Tribunal Penal Internacional para Ruanda (ICTR), em 8 de novembro de 1994; como o ICTY, trata-se dum tribunal ad hoc.

O Tribunal adquiriu legitimidade para julgar ${ }^{61}$ os acusados de violações aos direitos humanos perpetrados em Ruanda e países vizinhos entre $1^{\circ}$ de janeiro e 31 de dezembro de 1994; o Tribunal foi oficialmente instalado no ano seguinte, em Tanzânia.

A competência do Tribunal é para julgar os acusados (ruandeses e estrangeiros, hutus, tutsis e de qualquer outra etnia) contra os seguintes crimes contra a humanidade, de guerra, genocídio e violações das Convenções de Genebra, praticado em Ruanda e no estrangeiro.

O ICTR, de maneira geral, é bem parecido ao ICTY. Também é composto por três Câmaras de Julgamento e uma Câmara de Apelação; a quantidade de juízes titulares e substitutos é igual; sua competência também está traçada nos moldes do ICTY. Seu diferencial, entretanto, foi o de ser o primeiro autorizado a processar criminosos durante um conflito armado não-internacional. ${ }^{62}$

Atualmente, 52 casos foram concluídos (34 foram condenados, incluídos o ex primeiro-ministro; 10 aguardam apelação; 8 foram inocentados), 22 estão em progresso e 2 aguardam julgamento ${ }^{63}$.

A contribuição do ICTR para o direito penal internacional em muito se parece com a do ICTY, onde as críticas à formação do Tribunal e as defesas dos acusados se assemelham. No geral, a rapidez com que foram estabelecidos os tribunais ad hoc analisados resultou em alguns

\footnotetext{
${ }^{61}$ Quando confrontado com a acusação de um dos réus, Dusko Tadic, de que o ICTY não teria legitimidade para julgá-lo, por ter sido imposto pelo Conselho de Segurança, adquirindo assim um caráter político e não jurídico, desrespeitando os princípios da reserva legal, anterioridade, dentre outros, este afirmou, inovando juridicamente, que a prerrogativa do um tribunal de determinar sua própria competência não Ihe caberia, mas sim ao próprio Conselho de Segurança, afirmando que embora estabelecido com base em critérios políticos e não jurídicos, o Tribunal não carecia de legitimidade para julgar, sob caráter até de primazia sob os tribunais nacionais envolvidos no conflito, os acusados de violarem direitos humanos.

${ }^{62}$ MAIA, Marrielle, op.,cit., p.28

${ }^{63}$ http://www.unictr.org/Cases/tabid/204/Default.aspx (acessado em 09/10/2010)
} 
inconvenientes (enfoque especial nas críticas à legalidade dos próprios tribunais e no "atropelamento" a alguns direitos internacionalmente assegurados aos réus que foram negados); positivamente, os textos que criaram os tribunais ad hoc permitiram "total liberdade de interpretação aos juízes e a possibilidade de construção de regras de procedimento, prova e definição mais ampla dos elementos do crime." ${ }^{, 4}$

A cooperação jurídica internacional, entretanto, se mostra relutante no que se refere aos tribunais ad hoc; os países antigamente integrantes da Iugoslávia têm se esforçado para se adaptar às regras do ICTY, mas esbarram na política (exemplo clássico é o caso Kradizic, líder sérvio na Bósnia responsável por atrocidades na guerra, que permanece em território sérvio, que por sua vez se recusa a extraditar o criminoso para julgamento); pressões internacionais para Croácia, Sérvia, Bósnia, Ruanda e RDC têm favorecido a extradição de criminosos de guerra, apesar da nítida "mávontade" de governantes que não querem manifestar apoio ou repúdio aos acusados, temerosos da reação pública. Ruanda, por exemplo, vem encontrando sérias dificuldades para adaptar seu texto constitucional para cooperar com o ICTR. Isso fez com que, posteriormente, na elaboração do texto base do TPI, houvesse a previsão de que os Estados deveriam cooperar plenamente com o Tribunal, bem como se salientasse que no direito interno dos países signatários existissem procedimentos aplicáveis à todas as formas de cooperação jurídica específicas do Estatuto de Roma ${ }^{65}$.

$\mathrm{Na}$ esteira de criação do TPI, os tribunais ad hoc marcam um momento fundamental de consolidação do direito internacional penal rumo ao estabelecimento de um tribunal permanente para julgar criminosos de guerra; sua criação delineia um período de fortalecimento do direito internacional e enfraquecimento do conceito histórico de soberania, criando

\footnotetext{
${ }^{64}$ MAIA, Marrielle, op.cit., p.113

${ }^{65}$ http://www.fd.uc.pt/CI/CEE/OI/TPI/Estatuto_Tribunal_Penal_Internacional.htm (acessado em 09/10/2010)
} 
um ambiente, hoje por nós vivido, propício à jurisdição penal internacional, onde antes não seria possível.

Quanto a Ruanda, infelizmente, o cessar-fogo não garantiu a paz. Temerosos por um novo governo tutsi, 2 milhões de hutus refugiaram-se em países vizinhos, em especial a RDC; dezesseis anos após o genocídio correm notícias no mundo de que o exército de Ruanda, de maioria tutsi, com o apoio do governo de Ruanda e RDC, teria planejado o massacre de hutus refugiados, conforme a notícia:

"Após 16 anos do genocídio de Ruanda, um relatório da ONU sugere que dezenas de milhares de hutus, autores dos massacres contra os tutsis em 1994, poderiam ter sido vítimas de outro planejado posteriormente, como vingança, pelo Exército ruandês na República Democrática do Congo (RDC).

O relatório, publicado hoje em Genebra, cita "ataques sistemáticos e generalizados contra hutus refugiados na RDC" com sérios elementos que, se forem provados perante um tribunal competente, "poderiam ser qualificados de genocídio".

A possibilidade de um novo genocídio na região - dessa vez com os hutus como vítimas - já foi citada em um relatório preliminar e suscitou reações, sobretudo por parte de Ruanda, que ameaçou retirar suas tropas das forças de paz internacionais.

O clima tenso atrasou a publicação do relatório que, em sua versão final, indica que os massacres descritos poderiam constituir genocídio, mas que isso só pode ser julgado por um tribunal competente."

Como se pode ver, o conflito em Ruanda ainda não chegou ao fim.

\footnotetext{
${ }^{66}$ http://noticias.terra.com.br/mundo/noticias/0,,OI4712627-EI294,00ONU+disse+que+Exercito+de+Ruanda+teria+planejado+massacre+a+hutus.html (acessado em 09/10/2010)
} 


\section{O Estatuto de Roma e a Criação do Tribunal Penal Internacional}

$\mathrm{O}$ século $\mathrm{XX}$ presenciou uma série de violações aos hoje estabelecidos direitos humanos, fato este não só comprovados por farta documentação histórica, como também pela enorme quantidade de tratados versando, direta ou indiretamente, sobre o tema da $\mathrm{paz}^{67}$. A enorme quantidade de tratados sobre o tema gerou pouco efeito na prática, devido à ausência de uma instância internacional competente para lidar com as questões; os documentos internacionais tinham uma abrangência vasta (tratavam de crimes de agressão, guerra, genocídio, tortura, crimes contra a humanidade, drogas, falsificação, terrorismo, etc.), numa época em que o próprio direito internacional penal não tinha uma conceituação definida. Essa carência de conceituação, bem como a ausência de sistematização (muitos temas foram repetidamente discutidos em diferentes tratados, gerando quase que um vazio jurisdicional, uma ausência de autoridade na área internacional penal), impediram a criação de uma estrutura mais racional e prática.

À ausência de centralidade no tratamento dos temas concernentes ao direito penal internacional na maior parte do século XX, assoma-se o largo período conhecido por Guerra Fria, que impediu a consolidação de uma

\footnotetext{
${ }^{67}$ Farook Hassan descreve as características dos tratados penais internacionais no século XX:

"He used 8 'penal characteristics', the presence of any one of which would make a particular treaty penal in character. These 8 characteristics were: 1 ) if the treaty explicity or implicity created an international crime, 2) wheter a signatory nation's domestic law was obliged to incorporate a penal rule in its corpus juris, 3 ) if procedural mechanisms like extradition was involved, 4) if by treaty a penalty was imposed for the punishment of a person, 5) if modalities of cooperation between states on matters of criminal judicial administration were called for, 6) if a theory was discernible creating a penal jurisdiction, 7) if, generally, matters of criminal jurisdiction between states were involved, and finally, 8 ) if the doctrine of the defense of superior orders was directly or indirectly the subject of matter of the treaty."
}

FAROOK, Hassan (Relator). The origins, development and expanding scope of international criminal law. In: New horizons in international criminal law. Toulose: Érès, 1985,p.35. 
hegemonia jurídica internacional relativa ao tema, "engessada" pela disputa político ideológica de duas potências que dividiram o mundo em dois, sob vários aspectos. ${ }^{68}$

Apenas com o término da Guerra Fria é que a idéia de uma justiça penal internacional foge do escopo político-ideológico bipolar para uma efetiva tutela dos direitos humanos. É apenas no começo dos anos 90, com o fim da URSS e da divisão do mundo em duas super-potências, que a ONU ganha papel de destaque na efetiva proteção dos direitos humanos; ganha a agenda do dia a discussão em relação a efetiva criação de um Tribunal Penal permanente, que consiga garantir ao indivíduo a proteção aos seus direitos mais sagrados, bem como a punição daqueles que os violam, independentemente do status que possuam nacional ou internacionalmente. Para sua efetiva criação e legitimação, seria preciso não repetir erros cometidos quando da criação dos tribunais que o precederam, a dizer, os tribunais militares (Nuremberg e Tóquio) e os tribunais ad hoc (Ruanda e Iugoslávia). Seria preciso estabelecer um tribunal que não se vinculasse politicamente a determinados Estados, nem que violasse direitos assegurados universalmente aos réus; não poderia ser rotulado de "tribunal dos vencedores", nem ter sua legitimidade discutida pela forma como foi criado.

Os tribunais citados, apesar das pesadas críticas, serviram de base para a experiência necessária à criação do TPI. Foram seu ponto de partida, a comprovação de que a criação desse tribunal seria viável. A globalização cria, no cenário internacional, os elementos necessários para a implementação do tribunal; as barreiras comerciais afrouxam-se, os Estados vêem sua importância nos rumos da economia diminuir, ao passo que a interdependência econômica deles cria um ambiente de enfraquecimento da histórica noção de soberania, abrindo espaço para uma intermediação supranacional no que tange à proteção do indivíduo na esfera internacional,

\footnotetext{
${ }^{68}$ HOBSBAWN, op.cit., p.538.
} 
propiciando a criação de um tribunal penal permanente que assegurasse isso, além de garantir o devido processo legal e a aplicabilidade do direito penal internacional. $^{69}$

\subsection{Aprovação e entrada em vigor do Estatuto de Roma}

A aprovação do Estatuto do Tribunal Penal Internacional em Roma, em 1998, foi uma conquista da comunidade internacional, fruto de um lento processo de afirmação de direitos e responsabilidades individuais no cenário internacional que culminou com o estabelecimento de um tribunal com prerrogativas de julgar indivíduos violadores de direitos humanos, onde quer que estejam, independentemente da posição que ocupem frente a um determinado governo ou sociedade. Isso só se fez possível por causa da revisão da noção clássica de soberania absoluta dos Estados, processo também demorado, que correu em paralelo com a evolução do direito internacional, em especial o penal.

Hoje podemos dizer que "a soberania não consiste mais na liberdade dos Estados de atuarem isolada e independentemente, na busca de seus interesses próprios. A soberania consiste hoje na crescente participação do Estado na comunidade internacional. Soberano hoje é o Estado que integra o sistema internacional., 70

Participar na comunidade internacional, para o Estado, significa, entre outras formas, ser signatário de tratados internacionais; esses tratados, por sua vez, adquiriram importância, diversidade e abrangência não vistos antes da Segunda Guerra Mundial, dado o repúdio universal pelos acontecimentos daquela época. Desde então, a defesa dos direitos humanos passou a ser sistematicamente documentada e definida, a fim de criar mecanismos mais eficazes para a sua defesa, a fim de evitar que atrocidades

\footnotetext{
${ }^{69}$ JAPIASSÚ, op.cit., p.33

${ }^{70}$ CHAYES, Abram. The New Sovereignty. Apud Piovesan, F. O tribunal internacional e os crimes contra a humanidade. Mimeo (não publicado), 2000, p.5.
} 
fossem cometidas e defendidas pela falta de legislação internacional que definisse as violações dos direitos humanos. Ajunte-se a isso o tratamento conferido pelos Estados a seus nacionais, que se modificou desde a segunda metade do século passado até hoje, tendo como foco a proteção dos direitos humanos, já que se entende que "a proteção dos direitos humanos não pode, nem deve, reduzir-se ao domínio reservado dos Estados ou à jurisdição doméstica exclusiva."71

Não se pode reduzir ao domínio reservado doméstico porque as violações de direitos humanos perpetradas por nacionais muitas vezes não são julgadas pela justiça do respectivo país, seja por corrupção, influência ou vontade política, dentre outros motivos; muitas vezes a possibilidade de julgamento nacional de um criminoso violador desses direitos gera tanto desgaste político ao país que o poder judiciário do mesmo pode sair bastante prejudicado da situação, bem como as demais esferas de poder político; daí a importância da instauração de um tribunal internacional para julgar esses indivíduos, dentre outras razões.

Quase 50 anos se passaram, desde a criação da ONU, até que esta realizasse uma convocação diplomática com o intuito de discutir um projeto de estatuto para a criação do tribunal penal internacional permanente. Os tribunais militares e os tribunais ad hoc cumpriram seu papel, dadas as circunstâncias, mas não conseguiram preencher "o vazio jurídico decorrente da inexistência de uma instância internacional permanente e independente, com base em um instrumento de escopo universal, capaz de julgar os responsáveis pelos crimes mais graves de interesse internacional."72

Essa convocação diplomática foi incumbida de preparar um texto que pudesse ser largamente aceita pelos Estados participantes, devendo

\footnotetext{
${ }^{71}$ MAIA, Marrielle, op. cit., p.126

${ }^{72}$ SABOIA, Gilberto Vergne, Embaixador Brasileiro em palestra proferida pelo Chefe da Delegação Brasileira à Conferência dos Plenipotenciários das Nações Unidas sobre o Estabelecimento de um Tribunal Penal Internacional. Seminário internacional O Tribunal Penal Internacional e a Constituição Brasileira, Brasília, 29 de setembro de 1999.
} 
posteriormente ser levado à consideração dos mesmos em uma conferência para a aceitação. Essa conferência, chamada de Conferência dos Plenipotenciários, deu-se em Roma, em 17 de julho de $1998^{73}$, onde foi aprovado o texto do estatuto que deu origem ao TPI; a criação deste contou com 148 votos, dois quais 120 votaram a favor, 7 contra (EUA, Israel, China, Índia, Filipinas, Sri Lanka e Turquia), e 21 se abstiveram. As 60 ratificações necessárias para a validade do Estatuto ocorreu em 2002, passando o Tratado a vigorar em $1^{\circ}$ de julho de 2002. Os Estados Unidos assinaram o Tratado em 2000, tendo "desassinado" em $2002^{74}$, sob o governo Bush; mesmo assim o país, junto com a China e Rússia (que se absteve), todos membros do Conselho de Segurança da ONU, participam como observadores na conferência ${ }^{75}$.

O Brasil assinou o tratado em 7 de fevereiro de 2000, tendo ratificado-o em 20 de junho de 2002 e promulgado-o em 25 de setembro de 2002, por força do Decreto $n^{\circ} 4388^{76}$, a saber:

“O PRESIDENTE DA REPÚBLICA, no uso da atribuição que lhe confere o art. 84, inciso VIII, da Constituição, Considerando que o Congresso Nacional aprovou o texto do Estatuto de Roma do Tribunal Penal Internacional, por meio do Decreto Legislativo no 112 , de 6 de junho de 2002;

\footnotetext{
${ }^{73}$ http://www.iccnow.org/?mod=rome\&lang=es (acessado em 10/10/2010)

${ }^{74}$ Sobre o ocorrido, Valerio de Oliveira Mazzuoli disserta: “Os Estados Unidos, como é notoriamente sabido, vêm pretendendo concluir acordos bilaterais com os demais Estados-partes do TPI com a finalidade de excluir os seus nacionais da jurisdição do Tribunal, em flagrante violação dos propósitos do Estatuto de Roma. Este tipo de expediente internacional viola frontalmente a Convenção de Viena (1969), que prevê, no seu art. 18, que os Estados não podem frustrar o objeto ou a finalidade do tratado a concluir. Talvez seria esta uma hipótese de ato inexistente do Direito dos Tratados, ainda mais quando se tem como certa a obrigação dos Estados-membros em cooperar para com a jurisdição do Tribunal, como mandam os arts. 86 e ss do Estatuto de Roma.” (MAZZUOLI, Valerio de Oliveira, op.cit., p.39-40)

${ }^{75}$ http://neiarcadas.wordpress.com/2010/06/05/conferencia-de-revisao-do-estatuto-de-romado-tribunal-penal-internacional-por-cesar-yip/ (acessado em 10/10/2010)

${ }^{76}$ http://www.jusbrasil.com.br/legislacao/99584/decreto-4388-02 (acessado em 10/10/2010)
} 
Considerando que o mencionado Ato Internacional entrou em vigor internacional em 1o de julho de 2002, e passou a vigorar, para o Brasil, em 1o de setembro de 2002, nos termos de seu art. 126;

\section{DECRETA:}

Art. 1o O Estatuto de Roma do Tribunal Penal Internacional, apenso por cópia ao presente Decreto, será executado e cumprido tão inteiramente como nele se contém.

Art. 2o São sujeitos à aprovação do Congresso Nacional quaisquer atos que possam resultar em revisão do referido Acordo, assim como quaisquer ajustes complementares que, nos termos do art. 49, inciso I, da Constituição, acarretem encargos ou compromissos gravosos ao patrimônio nacional.

Art. 3o Este Decreto entra em vigor na data de sua publicação.

Brasília, 25 de setembro de $2002 ; 181^{\circ}$ da Independência e $114^{\circ}$ da República.

\section{FERNANDO HENRIQUE CARDOSO}

Luiz Augusto Soint-Brisson de Araujo Castro

Este texto não substitui o publicado no D.O.U. de 26.9.2002" (referência à adoção do texto do Estatuto de Roma; a partir dessa adoção, por força do art. $5^{\circ}, \S 2^{\circ}$ da $\mathrm{CF} / 88$, o Estatuto de Roma do Tribunal Penal Internacional integrou-se ao direito brasileiro com status de norma materialmente constitucional, passando a ampliar sobremaneira o "bloco de constitucionalidade" da nossa Carta Magna)

Ao finalizar os trabalhos da Conferência de Roma, em 17 de julho de 1998, o Secretário-Geral da ONU, Kofi Annan, descreveu a criação do TPI “como um presente de esperança para as futuras gerações e um gigantesco passo adiante na marcha dos Direitos Humanos Internacionais e na obediência à Lei", tratando-se de "uma conquista a qual, alguns anos atrás, ninguém pensaria ser possível."77

\footnotetext{
${ }^{77}$ Declaração oficial do Secretário-Geral da ONU, Kofi Annan, quando da cerimônia para a celebração da adoção do Tribunal Penal Internacional.
} 
Embora a adesão brasileira ao tratado tenha sido tardia, teve o Brasil uma participação fundamental na sua formação, quando se posicionou contrário a implementação da Resolução 1422 no seu corpo. Tal resolução, de 2002, foi aprovada pelo Conselho de Segurança da ONU, consistindo numa regulamentação que impedia ao recém criado TPI de julgar membros das forças de paz do Conselho de Segurança de serem julgados pelo tribunal, podendo qualquer processo contra esses membros ser paralisado por tempo indeterminado. ${ }^{78}$ Tal resolução foi posteriormente retirada do corpo do tratado.

\subsection{Estrutura e funcionamento do Tribunal}

O Estatuto do TPI é composto por um preâmbulo, 128 artigos e treze capítulos (I - Criação do Tribunal; II- Competência, admissibilidade e direito aplicável; III- Princípios gerais de direito penal; IV- Composição e administração do Tribunal; V- Inquérito e procedimento criminal; VI- O julgamento; VII- As penas; VIII- Recurso e revisão; IX- Cooperação internacional e auxílio judiciário; X- Execução de pena; XI- Assembléia dos Estados-partes; XII- Financiamento; XIII- Cláusulas finais). ${ }^{79}$

O TPI, ao contrário dos tribunais militares e ad hoc, possui competência subsidiária em relação às jurisdições nacionais (art. $1^{\circ}$; apesar das fortes críticas à implementação desse princípio ao Estatuto, ele foi inserido no corpo do tratado para potencializar o número de adesões ao tratado). As jurisdições nacionais continuam tendo primazia para processar e julgar os crimes cometidos por seus nacionais; a exceção ocorre quando resta comprovado que tais tribunais se mostram incapazes de levar adiante o

\footnotetext{
${ }^{78}$ http://iccnow.org/?mod=issues (acessado em 11/10/2010)

${ }^{79}$ http://www.dji.com.br/decretos/2002-004388/2002-004388.htm (acessado em 11/10/2010)
} 
julgamento, seja por pressão política interna, ou por ineficiência do sistema judiciário, lento demais para dar andamento ao processo.

Sobre o tema, afirma Zlata Drnas de Clément:

"Tal complementariedad no resulta coherente com la naturaleza del derecho penal internacional (I), ni con la percepción jurídico-socio-histórica de los más graves crímenes de derecho internacional que son de la competencia de la Corte (II)." 80

Ela complementa que:

"La incorporación del principio de complementariedad de la jurisdicción penal internacional frente a las jurisdicciones nacionales há sido uma consecuencia de circunstancias políticas existentes em el seno de la CDI y de la Conferencia diplomática de Roma. A pensar de resultar incoherente con el tipo de responsabilidad internacional penal e implicar una reducción de las facultades de la Corte, há permitido que el Estatuto fuera aprobado por uma gran mayoría de Estados. No obstante (...), atento a que los graves crímenes de competencia de la Corte sólo son pensables em el marco de um acto de Estado y a que, cuando entre em juego la responsabilidad internacional por la comisión de esas violaciones, solo cabe la sanción internacional, es que consideramos que la proclamada 'complementariedad' es una incoherencia en la visualización del sistema." (idem, p.68-69)

O interesse do TPI em obter informações relativas a um determinado julgamento realizado por tribunal nacional deve ser transmitido através de uma notificação, como manda o art.18 $\S \S 1^{\circ}$ e $2^{\circ}$; entretanto, se houver suspeitas de má condução do processo em tribunal nacional, o promotor do TPI pode, com base no art. $18 \S 6^{\circ}$, tomar as investigações necessárias ao processo, a fim de evitar, por exemplo, destruição de evidências.

Os crimes referidos pelo preâmbulo do Estatuto de Roma (genocídio, crimes contra a humanidade, crimes de guerra e crime de agressão) são imprescritíveis. Tais crimes somente poderão ser julgados pelo TPI após a instituição deste (TPI tem competência para julgar crimes cometidos apenas

\footnotetext{
${ }^{80}$ CLÉMENT, Zlata Drnas de. Principio de Complementariedad en el Estatuto de la Corte Penal Internacional: incoherencias sistêmicas, Anuario Argentino de Derecho Internacional, v.11, p.51, Córdoba, 2001-2002.
} 
após $1^{\circ}$ de julho de 2002), sendo que a entrada de um Estado-membro ao Estatuto impede ao TPI de julgar um nacional deste de crime cometido em data anterior à sua adesão, salvo se este assim o consentir (arts. 11 e 12 do Estatuto de Roma).

Tem o TPI jurisdição internacional, podendo atingir qualquer Estado-membro do Estatuto. O TPI é pessoa jurídica de direito internacional (personalidade jurídica distinta da de seus Estados-membros), estando plenamente capaz de desempenhar suas funções e objetivos. Poderá, então, o TPI exercer sua jurisdição sobre qualquer Estado-membro, sendo também possível, por acordo, exercê-lo sobre Estado não signatário do Estatuto, conforme artigo $4^{\circ}$. Sua jurisdição, conforme dito anteriormente, somente terá validade em casos onde as medidas internas dos países se mostrarem insuficientes, omissas ou suspeitas, referente ao processamento e julgamento de acusados.

Os juízes do TPI são eleitos entre pessoas de idoneidade moral, imparcialidade e integridade, que reúnam os requisitos para a função. No Brasil, os requisitos equivalem-se às condições necessárias para o cargo de Ministro do STF (CF art.101), como reputação ilibada, idade mínima de 35 anos, máxima de 65 e notável saber jurídico. São eleitos por um período máximo de 9 anos, sendo impossibilitado a reeleição.

O Tribunal é composto pelos seguintes órgãos (art.34 do Estatuto de Roma): a) Presidência (responsável pela administração da Corte); b) Uma Seção de Recursos, uma Seção de Julgamento em Primeira Instância e uma Seção de Instrução;c) O Gabinete do Procurador (órgão autônomo do Tribunal);d) A Secretaria (competente para assuntos não judiciais da administração do Tribunal).

Figura importante do Tribunal é o promotor, pelo Estatuto chamado de "Procurador". Ele é eleito por um escrutínio secreto de votos, por 
maioria absoluta da Assembléia dos Estados-partes, para um mandato de 9 anos, impossibilitado a reeleição. O Promotor atua de forma independente do Tribunal, devendo buscar informações referentes aos casos, e, posteriormente relatar se há fundamentação suficiente para que haja acusação referente aos crimes previstos pelo TPI (art.42 Estatuto de Roma). 


\section{Pressupostos da cooperação jurídica internacional}

Sobre a cooperação jurídica, explica Eneida Orbage de Britto Taquary:

"A cooperação jurídica internacional significa a colaboração entre os Países para mitigar o poder de um Estado dentro de seu território visando à realização de ações que somente poderiam ser praticadas sob a sua jurisdição e de interesse de outros Estados, visando à consecução de procedimentos jurídicos e de segurança no âmbito internacional e que favoreçam simultaneamente a diversas nações." ${ }^{\text {11 }}$

Continua a autora, afirmando que cooperação jurídica é "a assistência mútua entre Estados no desenvolvimento de atividade processual ou administrativa, cível ou penal, cujo procedimento, total ou parcial, deva se desenvolver em jurisdição estrangeira." ${ }^{82}$

A cooperação jurídica internacional, antes de basear-se em determinada legislação, baseia-se em princípios, tais como o dever jurídico e o dever moral de manutenção da segurança jurídica internacional ${ }^{83}$. $\mathrm{O}$ dever jurídico advém da celebração e ratificação de tratados internacionais, do costume internacional, do jus $\operatorname{cogens}^{84}$; o Estado, ao participar

\footnotetext{
${ }^{81}$ (1)TAQUARY, Eneida de Orbage Britto, op. cit., p. 31

${ }^{82}$ (2)Ibid, p. 32.

83 (1)ACCIOLY, Hildebrando; SILVA, G.E. do Nascimento e. Manual do Direito Internacional Público. 14 Ed. São Paulo: Saraiva, 2000. p.111

${ }^{84}$ A denominação de jus cogens encontra-se nos artigos 53 e 64 da Convenção de Viena sobre o Direito dos Tratados, a saber:
}

Art.53: Tratado em Conflito com uma Norma Imperativa de Direito

Internacional Geral (jus cogens)

É nulo um tratado que, no momento de sua conclusão, conflite com uma norma imperativa de Direito Internacional geral. Para os fins da presente Convenção, uma norma imperativa de Direito Internacional geral é uma norma aceita e reconhecida pela comunidade internacional dos Estados como um todo, como norma da qual nenhuma derrogação é permitida e que só pode ser modificada por norma ulterior de Direito Internacional geral da mesma natureza. 
internacionalmente de convenções ou conferências e ao ratificar tratados internacionais obriga-se, sob pena de sofrer sanções internacionais ou reprimendas diplomáticas, a obedecer aos termos impostos.

Nessa nova realidade em que vivemos, com o estreitamento das relações diplomáticas entre os Estados e a fragilização da exclusividade da jurisdição nacional para tratar sobre o tema, a proteção dos direitos humanos adquire status de jus cogens, devendo os Estados, então, garantir seu respeito, transformando-se, verdadeiramente, numa nova obrigação internacional. Sobre o tema, informa Juan Antonio Carrillo Salcedo:

"Esta obligacion internacional es, según una fórmula utilizada por la Corte Internacional de Justicia, uma obligación erga omnes; incumbe a todo Estado con respecto a la comunidad internacional em su conjunto, y todo Estado está interessado jurídicamente em la protección de los derechos del hombre. Esta obligación implica, además, un deber de solidariedad entre todos los Estados, con el fin de garantizar lo más rapidamente posible una protección universal y eficaz de los derechos humanos. ${ }^{~} 85$

O dever moral não se traduz em regras jurídicas de tratados internacionais, mas sim em princípios e direitos com natureza jurídica previstos em declarações internacionais, a fim de assegurar o cumprimento por parte dos Estados de determinado comportamento que propicie a proteção de determinados direitos conferidos aos indivíduos na esfera internacional. Não se trata, portanto de normas cogentes, de obrigações, mas sim de declarações com natureza jurídica de recomendação, a serem

Art.64: Superveniência de uma Nova Norma Imperativa de

Direito Internacional Geral (jus cogens)

Se sobrevier uma nova norma imperativa de Direito Internacional geral, qualquer tratado existente que estiver em conflito com essa norma torna-se nulo e extingue-se.

http://www2.mre.gov.br/dai/dtrat.htm (acessado em 13/10/2010)

${ }^{85}$ CARRILlO SALCEDO, Juan Antonio. Curso de Derecho Internacional Público - Introducción a su Estructura, Dinámica y Funciones. Madrid: Tecnos,1996, p.74 
seguidas pelos Estados, em respeito ao cumprimento dos tratados internacionais.

Assim, a cooperação jurídica internacional encontra seu fundamento no dever jurídico e moral que advém de todo e qualquer tratado internacional; além disso, baseia-se também no jus cogens e no direito costumeiro internacional. ${ }^{86}$

\subsection{Princípios da cooperação jurídica internacional}

Rege-se a cooperação jurídica internacional por três princípios básicos: pacta sunt servanda, reciprocidade e inaplicabilidade de tratado conflituoso com a lei nacional. ${ }^{87}$

Por meio do princípio pacta sunt servanta (os tratados devem ser cumpridos) o Estado se obriga a cumprir o disposto no tratado, sob pena de sanção internacional caso não o faça. Em que pese serem os Estados soberanos e detentores de vontade para firmar ou não tratados internacionais, na medida em que aderem a determinado tratado, nele se comprometem, devendo despender de meios para respeitar o que fora acordado, podendo sofrer reprimendas econômicas ou diplomáticas caso não o façam.

O princípio da reciprocidade refere-se à cooperação jurídica entre dois ou mais Estados que têm um objetivo ou interesse em comum sobre determinado tema ou fim; tal reciprocidade é demonstrada sob a forma de isonomia de tratamento, seja dentro de tratado comum às partes ou fora dele, onde as partes possuem igualdade formal e são tratadas de maneira igual, adicionando segurança jurídica à cooperação entre ambos.

\footnotetext{
${ }^{86}$ (2)IBID, p.112

87

http://www.uff.br/direito/images/stories/ARQUIVOS_PARA_DOWNLOAD/artigos_em_pdf /R_CEJ_Coopera_o.pdf (acessado em 13/10/2010)
} 
O princípio da inaplicabilidade das regras contidas no tratado quando conflituoso com a lei nacional é tema mais complicado. No Brasil, por exemplo, a adesão a determinado tratado internacional, com sua conseqüente ratificação e incorporação à legislação nacional, confere a este status hierárquico de norma jurídica federal; para deixar de cumprir regra exposta no tratado, alegando incompatibilidade com a lei nacional, o país que aderiu ao tratado teria que revogar o tratado, o que geraria óbvios incômodos diplomáticos ao Estado não mais signatário.

O Brasil, aderindo à teoria dualista (reconhecimento de duplo sistema jurídico), apenas reconhece o tratado internacional por ele assinado depois de passar por processo legislativo, reconhecendo status de lei federal aos tratados internacionais, sujeitos ao controle de constitucionalidade por parte do STF (CF arts. 49 I e 102 III b). Para que o tratado internacional seja válido no Brasil, portanto, faz-se necessário não só a adesão do país ao mesmo, mas também sua aprovação pelo Congresso, promulgação pelo Chefe de Estado, e declaração de constitucionalidade pelo STF; os tratados internacionais devem, portanto, serem incorporados legislativamente ao direito nacional, caso contrário não terão eficácia.

\subsection{Cooperação Jurídica Internacional na esfera penal}

A cooperação jurídica internacional está definida no Estatuto de Roma, em seu artigo 86, no capítulo IX, como "obrigação geral de cooperar"; nele está disposto que "Os Estados Partes deverão, em conformidade com o disposto no presente Estatuto, cooperar plenamente com o Tribunal no inquérito e no procedimento contra crimes da competência deste." Para que isso seja possível, torna-se imperioso que o Estado parte do tratado adéqüe seu ordenamento jurídico à realidade imposta pela adesão ao tratado. A não-cooperação por parte de um Estado signatário do Estatuto de Roma a um determinado caso poderá ensejar uma reprimenda internacional ao Estado em questão, elaborada pela Assembléia 
dos Estados Partes ou pelo Conselho de Segurança (art. 87 do Estatuto de Roma).

Para que não existam empecilhos à cooperação jurídica, "Os Estados Partes deverão assegurar-se de que o seu direito interno prevê procedimentos que permitam responder a todas as formas de cooperação especificadas", conforme o art.88 do Estatuto de Roma. Dentre as modalidades de cooperação jurídica internacional encontram-se as de entrega do autor do crime (art.89), a transferência temporária de uma pessoa para recolher depoimento, dentre outras formas de auxílio, como as descritas no art. 93 do Estatuto. A única forma que possui um Estado de se negar a prestar auxílio na cooperação jurídica ocorre quando este alega que a divulgação das provas e informações em questão pode afetar a segurança nacional.

Para que a cooperação jurídica ocorra faz-se necessário o respeito à algumas condições essenciais, tais como a reciprocidade de tratamento, a dupla incriminação, a escolha do procedimento a ser adotado, dentre outras.

Quanto ao procedimento a ser adotado, em relação à cooperação jurídica penal, tem-se que o STF não reconhecerá de carta rogatória proveniente de outro que não de poder jurídico estrangeiro ${ }^{88}$, entendendo ele ser a referida carta de natureza diversa. A cooperação jurídica em matéria penal ocorrerá entre poderes semelhantes; assim, poder jurídico estrangeiro poderá solicitar assistência do Judiciário brasileiro, assim como autoridade do Executivo, no desenvolvimento de relações diplomáticas (sob o foco da cooperação jurídica), poderá pedir auxílio a poder executivo estrangeiro. Com relação ao STF, é este exclusivamente competente para determinar o cumprimento de cartas rogatórias em território nacional, bem

\footnotetext{
${ }^{88}$ TAQUARY, op. cit., p.54
} 
como fazer solicitações via carta rogatória a poder judiciário estrangeiro (CF art.102), estando o procedimento concernente às cartas rogatórias previsto nos art.226 a 229 do Regimento Interno do STF. ${ }^{89}$ Com relação à homologação de sentença estrangeira (CF art.102), tem-se que é o STF detentor de sua competência originária, desde que aqui se produzam os mesmos efeitos que se produziriam no exterior, levando em consideração o duplo efeito.

Medidas constritivas de liberdade não poderão ser adotadas no Brasil por intermédio de carta rogatória, mas somente através de pedido de extradição e obediência aos princípios constitucionais penais e processuais brasileiros $^{90}$, por crime praticado por estrangeiro em território nacional ou por nacional no estrangeiro. Sob o tema, diz o CPP:

“Art. 780 - Sem prejuízo de convenções ou tratados, aplicar-se-á o disposto neste Título à homologação de sentenças penais estrangeiras e à expedição e ao cumprimento de cartas rogatórias para citações, inquirições e outras diligências necessárias à instrução de processo penal.

Art. 781 - As sentenças estrangeiras não serão homologadas, nem as cartas rogatórias cumpridas, se contrárias à ordem pública e aos bons costumes.”

A extradição, regulada no Brasil pela Lei $6815 / 1980^{91}$ (Estatuto do Estrangeiro), não ocorrerá sem que o país interessado nela formalize um pedido a favor do ato (art.76 e ss. da referida lei), sendo também necessário que haja um prévio acordo entre as nações com relação a extradições ou transferência de presos; deve haver também um acordo bilateral de cooperação jurídica penal entre os Estados em questão; tal reciprocidade, entretanto, só tem validade caso aceita pelo Poder Executivo.

\footnotetext{
${ }^{89}$ http://www.stf.jus.br/portal/cms/verTexto.asp?servico=legislacaoRegimentoInterno (acessado em 13/10/2010)

${ }^{90}$ TAQUARY, op. cit., p.58

${ }^{91}$ http://www.planalto.gov.br/ccivil/leis/L6815.htm (acessado em 13/10/2010)
} 
Juntamente com a previsão legal do cumprimento de carta rogatória e homologação de sentença estrangeira, o ordenamento jurídico brasileiro consolidou a noção de territorialidade, isto é, que "aplica-se a lei brasileira, sem prejuízo de convenções, tratados e regras de direito internacional, ao crime cometido no território nacional" ( $\mathrm{CP}$ art. $\left.5^{\circ}\right)$. Portanto, o princípio da territorialidade é aplicado como regra no ordenamento jurídico brasileiro, admitindo-se apenas excepcionalmente que lei estrangeira venha a ser aplicada em território nacional, em casos devidamente qualificados.

As leis, de qualquer natureza, são a expressão da soberania estatal, logo sendo aplicadas em seu território, onde guardam jurisdição, poder coercitivo, soberania. Atualmente essa situação vem sofrendo mudanças, já que os Estados vêm tentando exercer a sua soberania através de acordos multilaterais, redefinindo o conceito de territorialidade em defesa não só dos direitos humanos, mas de uma melhoria na repressão à criminalidade internacional, complementando à sua jurisdição a inclusão da jurisdição internacional, cooperando com os demais Estados. Sobre o tema, disserta Eneida Orbage de Britto Taquary ${ }^{92}$ :

"Não se trata de aplicar e dar eficácia às leis estrangeiras no território nacional, mas, de participar da elaboração de princípios e normas internacionais, que após inseridos nos tratados internacionais, são acatados pelos Estados para complementar a ordem jurídica interna; manter ordem jurídica internacional; promover e tutelar os direitos humanos; manter a paz mundial e reprimir a criminalidade em âmbito internacional."

Esses fundamentos serviram, então, como base para excepcionar o princípio da territorialidade, seja através de convenções, tratados ou regras de direito internacional privado. Tal princípio é hoje excepcionado em relação a algumas embarcações, por exemplo; um navio público em altomar ou que esteja em território nacional ou estrangeiro é considerado extensão do território nacional (critério semelhante serve para os estabelecimentos diplomáticos); embarcações estrangeiras em território

\footnotetext{
${ }^{92}$ TAQUARY, op. cit., p.63
} 
nacional, desde que públicas, são consideradas território da bandeira que ostentam; os critérios para embarcações privadas são outros, servindo como lei aquela relacionada com a bandeira dela ${ }^{93}$.

Outros princípios servem de aplicação no direito penal internacional, dentre eles os da nacionalidade e da universalidade. O Brasil adotou o princípio da nacionalidade ativa, prevendo que "ficam sujeito à lei brasileira, embora cometidos no estrangeiro: os crimes praticados por brasileiros" (CP art. $\left.7^{\circ}, \mathrm{II}, \mathrm{b}\right)$. Assim, tal princípio tem aplicabilidade para atingir os brasileiros aonde quer que estejam, pois não se admite que sejam descumpridas as leis mesmo estando em território estrangeiro.

O princípio da universalidade está disposto no art. $7^{\circ}$, II, do $\mathrm{CP}$, ao dispor que "ficam sujeitos à lei brasileira, embora cometidos no estrangeiro: os crimes que por tratado ou convenção, o Brasil se obrigou a reprimir". Isso quer dizer que a aplicação da lei brasileira ao autor do crime ocorrerá quando este estiver em território brasileiro, independentemente do bem jurídico atingido e das nacionalidades envolvidas, estando tal princípio sujeito a algumas condições, elencadas no mesmo artigo, tais como entrar o agente em território nacional, ser o fato punível também no país em que foi praticado, ser o referido crime passível de extradição, não ter sido o agente absolvido no estrangeiro, dentre outras.

Diversos princípios em matéria de direito penal e direito processual penal foram adaptados aos tribunais internacionais do século XX, chegando efetivamente ao TPI (tais como as definições de crimes de guerra, genocídio, crimes contra a humanidade, contra a paz, responsabilidade individual internacional, dentre outros). Isso propiciou um avanço na cooperação jurídica internacional entre os Estados e entre os Estados e instituições auxiliadoras no combate à criminalidade internacional, como a INTERPOL, por exemplo ${ }^{94}$. Esse progresso na cooperação jurídica

\footnotetext{
${ }^{93}$ Sobre o tema, ler MELLO, Celso D. de Albuquerque, Curso de Direito Internacional Público,

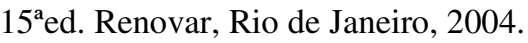

${ }^{94}$ MELLO, Celso D. de Albuquerque, op.cit. p.977.
} 
internacional propiciou um avanço ao TPI em relação aos tribunais anteriores, no que se refere ao fortalecimento do vínculo entre os Estados para o aperfeiçoamento e elaboração de novos princípios que passaram a ser adotados na prática, tentando corrigir equívocos que restaram atrelados aos modelos passados de tribunal internacional.

Tal cooperação jurídico-penal dos Estados terminou por consolidar a união dos mesmos em torno de um propósito comum, qual seja, a criação do TPI. Essa comunhão de interesses, essa troca entre nações, segundo Marcel Mauss ${ }^{95}$, propiciou a formação de uma sociedade internacional, baseada nos interesses de dar e receber algo (princípio da reciprocidade); logo, todo Estado que coopera juridicamente na esfera internacional penal (investigando crimes, possibilitando extradições, punindo criminosos etc.) pode também ser auxiliado quando necessitar. É a mútua necessidade de cooperação entre os Estados (frente à nova realidade do crime, que não mais se limita a fronteiras para atuar; veja o narcotráfico, por exemplo, com seu amplo emprego de subterfúgios para a distribuição de drogas ilícitas nos quatro cantos do globo, desde o emprego de camponeses no cultivo das matérias-primas, até o uso de instalações químicas para o refino da mesma, passando pela distribuição desta, das formas mais variadas possíveis, desde o emprego de "mulas", aliciando menores e pessoas necessitadas, até a construção de submarinos descartáveis para a travessia das fronteiras marítimas mais vigiadas; a sofisticação vivida pelos maiores cartéis de drogas nos últimos anos desafia o poder de fiscalização e punição do Estado, obrigando o mesmo a buscar cooperação internacional com seus semelhantes para enfraquecer tal atividade ilícita) porque favorece a criação de uma jurisdição penal internacional e seu fortalecimento ocorre

\footnotetext{
${ }^{95}$ Marcel Mauss foi um sociólogo francês que afirmava que o interesse comum através de trocas entre os diferentes povos auxiliava a interatividade entre eles e estabelecia laços de amizade, resultando em mudanças comportamentais individuais e coletivas; porém, afirma o sociólogo, o indivíduo não reflete a coletividade, sendo portanto importante que as trocas, pelos mais amplos motivos, sejam intensificadas, a fim de gerar uma minimização da estratificação entre nações e indivíduos, contribuindo para a manutenção da paz. Sobre o tema, ler MAUSS, Marcel. Ensaio sobre a dádiva, Ed. Edições 70.
} 
simultaneamente com o estreitamento das relações diplomáticas entre os Estados, com o intuito de gerar mecanismos que facilite a punição de criminosos e dificulte a perpetuação de violações de direitos humanos mundo afora.

Assim, a criminalidade internacional passa a ser tipificada e punida pela sociedade internacional, e não mais apenas pelos vencedores de um conflito armado ou potências estatais. 


\section{Fundamentos do Tribunal Penal Internacional}

A criação do TPI gerou a necessidade de se redefinir conceitos solidificados ao longo dos séculos, que formavam a base de sustentação dos Estados nacionais, bem como supunha a criação de novos conceitos que melhor caracterizassem a nova realidade alcançada pelo advento de um tribunal com jurisdição penal internacional. O TPI foi criado com o intuito de alterar a ordem internacional, preparando-a para uma realidade em que a convivência dos Estados seria crucial para o novo cenário político, daí a importância da cooperação entre as nações a fim de alcançar objetivos em comum, dentre eles o de assegurar a vivência em um mundo menos violento, onde os violadores de direitos humanos não teriam como escapar da justiça. Dessa nova realidade emergiram alguns princípios e fundamentos essenciais para o funcionamento do TPI; alguns foram criados, outros modificados, sendo os principais classificados agora neste capítulo.

\subsection{Paz Perpétua}

O conceito de "paz perpétua" alcançou seu pleno desenvolvimento através do filósofo Emanuel Kant, que publicou em 1795, ainda exultado com a Revolução Francesa, um opúsculo intitulado Zum ewigem Frieden, ou, simplesmente, "A Paz Perpétua". 96

Embora tenha sido o mais eficiente divulgador do conceito, Kant não foi o primeiro a fazê-lo, onde podemos traçar um longo histórico da evolução do mesmo; sobre o tema, Celso D. de Albuquerque Mello afirma serem os diversos projetos históricos de paz perpétua como sendo

\footnotetext{
${ }^{96}$ http://educaterra.terra.com.br/voltaire/cultura/kant_paz.htm (acessado em 14/10/2010)
} 
antecedentes necessários para a formação das organizações internacionais atuais, dentre elas, o TPI. Ele divide-os em dois, quais sejam, aqueles de origem continental e os de origem anglo-saxã. Ao primeiro grupo, afirma o autor que seus teóricos procuraram construir a sociedade internacional à imagem da sociedade estatal, com sanções e competências amplas; ao segundo grupo, afirma o autor que seus teóricos acreditavam que para a existência de uma sociedade internacional organizada não haveria necessidade de sanções, apenas bastando que houvesse apelo morais. ${ }^{97}$

A conceituação de paz perpétua modificou-se ao passar dos séculos, acompanhando os câmbios nas sociedades e nos próprios Estados, bem como na maneira como se relacionavam entre si.

$\mathrm{Na}$ Idade Média, o primeiro trabalho importante sobre o tema cabe a Pierre Dubois, que com seu livro De recuperatione Terrae Sanctae, de 1305, propunha a criação de uma república cristã universal, chefiada por um conselho de sábios e arbitrado pelo Papa ${ }^{98}$.

Em 1315, Dante Alighieri dá sua contribuição para a paz perpétua em De Monarchia, onde sugere a criação de uma monarquia universal, chefiada por único Imperador, capaz de assegurar uma paz universal ${ }^{99}$. Para Dante, já que toda a humanidade se ordenava a um fim único, seria lógico supor que apenas um (o Imperador) a coordene. Outro pensador contemporâneo, Marsílio de Pádua, chegou á idéia semelhante em Defensor Pacis, de 1324, incitando à criação de um império universal como forma de assegurar a paz entre a humanidade.

O primeiro chefe de Estado a fazer menção à paz universal foi o Rei da Boêmia, Georg Von Podriebrad, que em 1464 propõe um projeto de paz perpétua ao Rei da França, Luís XI; tendo como pano de fundo a queda de Constantinopla pelos turcos, o monarca sugere a criação de uma federação

\footnotetext{
${ }^{97}$ MELLO, op.cit., p.593/594

${ }^{98}$ MELLO, op.cit., p.594

${ }^{99}$ http://www.revistahistoria.ufba.br/2010_1/a01.pdf (acessado em 14/10/2010; p.7)
} 
entre os príncipes cristãos, que proibiria a guerra entre católicos e fomentaria o custeio de um vasto exército cruzado capaz de expulsar os muçulmanos da antiga capital do Império Bizantino. ${ }^{100}$

O primeiro a citar a paz perpétua como modelo capaz de assegurar as fronteiras estatais foi Erasmo, em Querela pacis, de 1517; também inova ao sugerir a arbitragem como forma de regulamentar as querelas entre os monarcas europeus e seus exércitos, tendo como pano de fundo os longos anos de guerra entre França e Espanha nesse século.

Emeric Crucé propõe, em 1625, em Nouveau Cynée, que fosse criada uma federação de Estados, tendo Veneza como a capital, onde as decisões fosse obtidas por meio de votação em assembléia.

John Beller foi o primeiro a sugerir a formação de um parlamento europeu, em 1710, em sua obra Essay towards the present and future peace of Europe by the establishment of na European Diet. Jeremias Bentham vai além, sugerindo não só a criação de um parlamento europeu, como a criação de um exército europeu e de um tribunal de arbitragem, em 1843, com seu livro póstumo A plan for universal and perpectual peace.

Johann Caspar Bluntschili foi o primeiro a falar em União Européia, em 1881, sugerindo também a criação de uma federação e um parlamento comum.

O primeiro movimento pacifista europeu (1815-1867) ocorreu na Grã-Bretanha; as organizações internacionais com teor pacifista proliferaram no século XX, em especial após a $1^{\text {a }}$ Guerra Mundial.

Como se pode ver, o tema data de séculos e exerceu um enorme fascínio em diversos teóricos, que viveram nas mais variadas sociedades, separadas pelo espaço e pelo tempo.

Mas a maior colaboração ao tema deve-se, de fato, a Emanuel Kant. Ele, ao sugerir o estabelecimento de um programa que permitisse a paz permanente entre as nações, delimitou três pontos que seriam essenciais

\footnotetext{
${ }^{100}$ http://www.leonildocorrea.adv.br/curso/org1.htm (acessado em 14/10/2010)
} 
para a paz perpétua, quais sejam, o direito anterior à guerra, o direito durante o conflito e o direito pós-guerra.

Afirmava o filósofo que os Estados viviam eternamente em conflito, mesmo que não estivesse em guerra, pelo simples fato de não possuírem um tratado internacional celebrado sobre o tema da paz, que estabelecesse um "contrato social originário"101; esse contrato, por sua vez, obrigaria os Estados a não atuarem em conflitos internos de outros Estados, também determinando uma aliança que protegesse os Estados signatários de uma eventual invasão estrangeira.

Ele afirma que os Estados, nas suas relações externas, vivem ainda em um estado não-jurídico, condizente com o estado de natureza ao qual se encontram. Sendo o estado de natureza injusto, porque não consegue proteger a população, faz-se necessário que os Estados hajam e fundem uma federação, formando uma união de povos que se caracterize pela não ingerência de um Estado nos assuntos domésticos de outro. Tal federação não seria um Estado em si, mas uma reunião de Estados autônomos e soberanos, baseada na cooperação entre suas partes.

Kant se filiou a doutrina do pacifismo democrático, afirmando que as guerras estão atreladas ao arbítrio do príncipe; daí a necessidade, junto da criação da Federação, de se elaborar constituições republicanas, que limitassem o poder do príncipe e assegurasse à população certos direitos; assim, a paz seria assegurada na medida em que o Estado absoluto (onde as guerras eram decididas por dívidas entre parentes distantes que chefiavam um Estado, onde o exército era bancado pelo monarca, onde não eram conferidos direitos à população,onde guerras de sucessão ocorriam comumente, etc.) desse lugar ao Estado soberano, democrático e participativo no cenário internacional. ${ }^{102}$

\footnotetext{
${ }^{101}$ BOBBIO, Norberto. Direito e Estado no pensamento de Emanuel Kant. Brasília, UNB, 1997, p.160.

${ }^{102}$ Sobre o tema, ler KANT, Emanuel. A Paz Perpétua, Ed Martins Fontes
} 


\subsection{Soberania}

Soberania é um conceito eminentemente político, atrelado a duas noções inseparáveis e complementares, quais sejam, supremacia e independência ${ }^{103}$. Supremacia, pois no plano interno nada deve se sobrepor às decisões emanadas do Poder Público; no plano externo, o Estado encontra-se em igualdade junto aos demais Estados, no plano internacional (já houve tempo em que os Estados não se relacionavam em igualdade, numa época em que eram tratados de acordo com a sua "classificação" entre civilizado, semi-civilizado e bárbaro; Rui Barbosa foi um feroz crítico dessa diferenciação de tratamento entre as nações na Conferência de Haia, exigindo que as nações européias reconhecessem a igualdade na forma de tratamento entre os demais Estados; anteriormente a isso, talvez fosse possível creditar ao Brasil sua "ascensão" de nação semi-civilizada para seu reconhecimento frente à Europa na chamada "Questão Christie", onde, ineditamente, reconheceu-se, via arbitramento, ganho de causa ao Império do Brasil em conflito diplomático com a Grã-Bretanha, fato este impossível de acontecer se não fossem as duas nações equiparadas, internacionalmente, em tratamento ).

Sobre a soberania, afirma Miguel Reale ser ela "o poder de organizar-se juridicamente e de fazer valer dentro de seu território a universalidade de suas decisões nos limites dos fins éticos da convivência". ${ }^{104}$

$\mathrm{O}$ autor Celso de Albuquerque Mello, por sua vez, considerava o conceito de soberania algo por deveras complicado, pois trata-se de um conceito jurídico indeterminado, dada a dificuldade de se definir as noções de ordem pública, de bons costumes, e conceitos outros que se relacionam

\footnotetext{
${ }^{103}$ BONAVIDES, Paulo. Ciência Política. São Paulo: Malheiros, 1997, p.123/124.

${ }^{104}$ REALE, Miguel. Teoria do direito e do Estado. São Paulo: Martins Fontes, 1960, p.127
} 
com o conceito de soberania. Assim, dizia ele tratar-se de um conceito eminentemente político, secundariamente jurídico.

Apesar do conceito de independência existir desde os tempos dos antigos gregos, a noção de soberania aparecerá por primeira vez na Idade Média; foi a noção de soberania que pôs fim a sociedade feudal e deu início ao Estado moderno. ${ }^{105}$

O primeiro teórico a tratar do conceito de soberania foi o jurista francês Jean Bodin, que publicou, em 1576, sua principal obra, Les six livres de la République ("Os seis livros da República"). Nele, o autor trata a soberania como sendo um poder praticamente ilimitado (limitado apenas pelas leis de Deus e a lei natural) e perpétuo; a soberania é, para ele, absoluta dentro dos limites estabelecidos pela lei. O poder soberano, segundo ele, somente existiria quando o povo despisse de seu poder soberano e o entregasse ao governante; sua obra perde em atualidade ao afirmar que o poder conferido ao soberano é reflexo do divino, e que portanto os súditos devem, obediência integral a ele. ${ }^{106}$ Também pioneiros no tema foram Grócio e Hobbes. ${ }^{107}$

O conceito europeu de soberania permaneceu intacto por quase trezentos anos, até o advento da Revolução Francesa; até lá, havia um consenso em relacionar a soberania com o equilíbrio de forças na Europa, que não poderia permitir que emergisse uma única potência no continente. Com a Revolução Francesa, o conceito básico de soberania permanece igual, somente mudando de foco com relação ao seu titular. O receio de ambos os períodos históricos se concretiza com as conquistas imperiais de Napoleão, que redefiniu o mapa da Europa e seu jogo de poderes.

$\mathrm{O}$ conceito de soberania ilimitada surge no final do século XIX, sob influência direta de Hegel; surge, então o monismo nacionalista, onde a

\footnotetext{
${ }^{105}$ FERRAJOLI, Luigi. La soberania en el mundo moderno. In derechos y garantias. La ley del más débil. Madri: Trotta, 1999, p.125

${ }^{106}$ http://pt.wikipedia.org/wiki/Jean_Bodin (acessado em 15/10/2010)

${ }^{107}$ FERRAJOLI, op.cit., p.127
} 
soberania não seria limitada nem pelos direitos divino e natural (primazia do direito interno; outro grande defensor dessa corrente foi Hans Kelsen), tendo sido largamente utilizada pelos Estados mais autoritários europeus no período entre as grandes guerras. Para essa visão, o direito internacional passaria a ser apenas como uma decorrência do direito interno; igualmente, o arbítrio (soberania) de outro Estado só encontra barreira no arbítrio de outro Estado, nunca nas regras de direito internacional. ${ }^{108}$

As duas grandes guerras puseram em cena a questão da soberania, onde num mundo sem poderosas organizações internacionais os Estados defenderam com emprego bélico nunca antes visto sua soberania, sua própria existência enquanto Estado.

Com o fim da $2^{\mathrm{a}}$ Guerra Mundial houve um processo de descolonização incentivado pela ONU. Isso gerou como conseqüência um aumento brusco no número de Estados independentes, soberanos. Optou-se, então, pela criação de um sistema internacional capaz de manter a paz e coibir graves violações de direitos humanos. Nos dizeres de Carlos Eduardo Adriano Japiassú:

"Pode-se dizer que a Carta das Nações Unidas marcou o surgimento de um novo modelo de soberania, deixando de lado um sistema baseado em tratados internacionais, que passaram a constituir um autêntico ordenamento jurídico supraestatal". ${ }^{109}$

Com o advento da ONU o conceito de soberania é readequado aos novos tempos, reformulado para se encaixar nas mudanças pelas quais passaram as sociedades e os Estados ao longo do século XX. Sobre o tema, afirma Ferrajoli:

"La soberanía, que había quedado vacía de contenido hasta disolverse en su dimensión interna con el desarrollo del Estado constitucional de derecho, decae también en su dimensión externa en presencia de um sistema de normas internacionales que

108

http://www.uj.com.br/publicacoes/doutrinas/7009/Breve_Analise_dos_Tratados_Internacion ais_no_Direito_Brasileiro (acessado em 15/10/2010)

${ }^{109}$ JAPIASSÚ, op. cit., p.131 
pueden ser caracterizadas como ius cogens, es decir, como derecho inmediatamente vinculante para los Estados miembros. En el nuevo derecho internacional no sólo los Estados, sino también los indivíduos y los pueblos."

O final do século XX presenciou outro câmbio na noção básica de soberania, com a criação dos grandes blocos econômicos, em especial com a da União Européia. O Tratado de Maastricht ${ }^{111}$ determinou a colaboração jurídica, econômica, criou política externa e de segurança em comum. A soberania nacional persiste na Europa, mas ela adquiriu novas feições, na medida em que os laços da comunidade européia como entidade em si se fortalecem.

O que se observa hoje em dia é que o conceito de soberania encontra-se em crise, sobretudo causado pela globalização, que introduziu uma nova ordem internacional; concernente à proteção dos direitos humanos fica óbvio que a velha noção de soberania encontrará cada vez mais empecilhos para sua existência, devendo os Estados encontrarem novas formas de legitimar sua soberania, conferindo a devida proteção aos direitos humanos. Sobre o tema, Celso Albuquerque de Mello chega a dizer que a noção de soberania está fadada a desaparecer com os Estados, na medida em que o mundo se integra cada vez mais, rompendo fronteiras nesse movimento contínuo e interminável. ${ }^{112}$

Concernente à criação do TPI e a noção de soberania, alguns Estados fizeram oposição, receosos de que altos funcionários e mandatários seus viessem algum dia a responder em tribunal por violações de direitos humanos. Também se opuseram com a alegação de que um Tribunal com jurisdição penal internacional permanente poderia causar embaraços políticos a alguns Estados nacionais, por razões políticas.

Sobre o tema, Carlos Eduardo Adriano Japiassú afirma o seguinte:

\footnotetext{
${ }^{110}$ FERRAJOLI, op. cit., p. 145

${ }^{111}$ http://www.historiasiglo20.org/europortug/maastricht.htm (acessado em 15/10/2010)

${ }^{112}$ MELLO, op.cit.., p. 22
} 
"Mas, apesar de todos os argumentos apresentados, é preciso ressaltar que, de maneira geral, a soberania, com todas as reservas que esse conceito deve receber na atualidade, não seria verdadeiramente afetada pelo Tribunal, já que um Estado somente estaria sujeito à jurisdição penal internacional tendo ratificado a Convenção de Roma, o que faria dele um Estado-membro."

Ou seja, somente faz parte da Convenção de Roma quem quer. Uma vez signatário, não há motivo para deixar de cumprir uma decisão ou resolução do TPI, já que pela Convenção o Estado aquiesceu aos termos de criação do TPI e subordinou-se à ordem internacional; não pode, portanto, a soberania ser alegada como obstáculo à adequação de um Estado à realidade internacional.

\subsection{Cidadania}

A cidadania é outro conceito que vem sofrendo alterações devido ao processo de globalização e término da bipolarização do mundo. Ela tem sido ampliada sob o ponto de vista político e social, relativo ao Direito, sofrendo poucas alterações, atualmente, na área jurídica.

Seu conceito surgiu na Grécia Antiga, mais precisamente em Atenas. Num discurso que entrou para a História, Péricles saúda os soldados atenienses que regressaram da Guerra do Peloponeso, reconhecendo não só sua bravura em combate, mas também seu sacrifício pela cidade, Atenas, o que fazia deles verdadeiros cidadãos. ${ }^{114}$

Atenas não foi apenas o palco da criação da noção de cidadania, foi também onde ela foi mais exercitada na antiguidade. Dela decorriam três pressupostos: primeiro, que as decisões seriam tomadas pela maioria dos cidadãos, a partir do voto, sendo possível a cada um exercitar, através da oratória, seu ponto de vista sobre determinado tema em pauta, criticando-o positiva ou negativamente, incitando ao debate; segundo, que seus

\footnotetext{
${ }^{113}$ JAPIASSÚ, op.cit., p.135.

${ }^{114}$ BARRETO, Vicente. O conceito moderno de cidadania. In: Revista de Direito Administrativo, n ${ }^{\circ} 192$, Rio de Janeiro. Ed. ${ }^{a}$ Renovar, 1993, p. 31
} 
governantes eram escolhidos pelo mérito, como já salientava Sócrates; terceiro, que o histórico familiar ou status social não seriam determinantes para que a manifestação de opinião do cidadão seja acolhida ou rechaçada, bem como não seria também prerrogativa para assumir determinado cargo político-administrativo, nem pressuposto para determinados direitos exclusivos. A cidadania, em Atenas, portanto, só era efetiva devido à participação política de seus integrantes.

Na modernidade, segundo Ricardo Lobo Torres ${ }^{115}$, a cidadania viria a corresponder a três grupos de direitos e obrigações, a saber: direitos civis (conquistados no século XVIII), direitos políticos (século XIX) e direitos sociais (século XX). Há quem fale numa quarta modalidade de direitos, os chamados direitos pós-modernos, fruto de uma evolução na noção de cidadania e relações internacionais.

O conceito jurídico de cidadania envolve, tradicionalmente, o pleno exercício de direitos políticos e civis por um determinado cidadão de um determinado Estado. "Cidadão é o membro de uma comunidade nacional, seja ele nato ou naturalizado, sujeito aos deveres por ela impostos e beneficiários dos direitos por ela atribuídos (...).”116

A cidadania tradicional vem sofrendo mudanças. Sobre o tema, Clémerson Merlin Clève relata:

“(...) a cidadania não se resume na possibilidade de manifestar-se periodicamente, por meio de eleições para o Legislativo e para o Executivo. A cidadania vem exigindo a reformulação do conceito de democracia."117

Hoje fala-se em manifestação de diversas cidadanias (cidadania local, nacional, comunitária, virtual e mundial). Têm contribuído para isso

\footnotetext{
${ }^{115}$ TORRES, Ricardo Lobo. Cidadania multidimensional na era dos direitos. In: Teoria dos direitos fundamentais. Rio de Janeiro. Ed. ${ }^{a}$ Renovar, 1999, p. 244

${ }^{116}$ JAPIASSÚ, op.cit., p.138-139.

${ }^{117}$ CLÈVE, Clémerson Merlin. Teoria do direito constitucional. São Paulo. Edª . Acadêmica, 1993, p. 16
} 
uma série de fatores, tais como: a efetivação dos tratados de direitos humanos, em especial na ONU; o término da bipolarização mundial entre capitalismo e comunismo; os avanços tecnológicos, em especial da internet, que disponibiliza às pessoas uma fonte de informação e comunicação nunca antes vista; a globalização, responsável pela maior troca de informação, mercadorias e fluxo migratória da história, bem como suas mazelas (tráfico de drogas, tráfico de mulheres, etc.).

A cidadania local manifesta-se através da relação que tem o indivíduo com a cidade onde vive; os câmbios na política nacional não são capazes de alterar o vínculo do indivíduo com seu meio. A cidadania nacional alcançou seu auge com o liberalismo econômico (século XIX) e nacionalismo exacerbado (primeira metade do século XX), enfraquecendose na entrada do século XXI, com a globalização; a cidadania comunitária advém da entrada do país do qual é nacional para um determinado bloco político-econômico. As mudanças mais visíveis ocorrem na União Européia, onde seus cidadãos possuem de fato dois direitos distintos, os nacionais e os provenientes da própria União; a cidadania virtual eleva a níveis nunca antes vistos a noção de liberdade de expressão, onde num campo de difícil fiscalização dos Estados nacionais a manifestação de vontade encontra uma nova fronteira, capaz de gerar e formar opinião num ritmo nunca antes visto; a cidadania mundial é decorrência direta da globalização, onde num mundo os as pessoas cada vez mais se relacionam com estrangeiros no seu país e como estrangeiros fora dele. É uma forma de direito que vislumbra a "possibilidade de prevalência dos tratados internacionais sobre a lei interna". ${ }^{118}$

$\mathrm{Na}$ visão de Cançado Trindade, a relação dos Estados com seus cidadãos e com estrangeiros que ali residem mudou.

"O tratamento de seus cidadãos por um Estado deixa de ser um questão interna, para se tornar um fenômeno internacional, na medida em que há problemas que a todos

${ }^{118}$ JAPIASSÚ, op. cit., p. 142 
atingem, como os danos ambientais e, especificamente no Direito Penal, o genocídio. Esses direitos devem ser de validade universal, por serem meios de concretizar a dignidade humana." 119

A idéia de uma jurisdição penal permanente adéqua-se perfeitamente às transformações pelas quais vem passando a noção clássica de cidadania. É mais um anseio da população global que vem a ser atendido, a fim de se assegurar a justiça a todos os indivíduos, não importando a sua posição na sociedade onde se vive, sua etnia, orientação sexual e religiosa, dentre outros fatores. É fruto direto do processo de globalização, onde essa jurisdição penal só se faz possível quando "o indivíduo deixa de ser ligado apenas aos Estados nacionais e às suas questões particulares."

\subsection{Reserva Legal}

O chamado princípio da reserva legal encontra abrigo na legislação brasileira, estando enunciada no $\operatorname{art} .1^{\circ}$ do $\mathrm{CP}$, com os dizeres: "Não há crime sem lei anterior que o defina. Não há pena sem prévia cominação legal."

Sobre o tema, Claus Roxin ${ }^{121}$ elabora uma definição:

"Es decir, que el ordenamiento jurídico no sólo há de disponer de métodos e médio adecuados para la prevención del delito, sino que también há de imponer límites al empleo de la potestad punitiva, para que el ciudadno no quede desprotegido y a merced de uma intervención arbitraria o excesiva del "Estado Leviatán".

Em outras palavras, um ordenamento jurídico, através do seu direito penal, deve proteger seus cidadãos, não apenas contra outros cidadãos que acabem violando algum dispositivo do código penal em si, como também

\footnotetext{
${ }^{119}$ TRINDADE, Antonio Augusto Cançado. Tratado de direito internacional dos direitos humanos. Porto Alegre. Ed. ${ }^{a}$ Sergio Antonio Fabris, 1997, p.27

${ }^{120}$ JAPIASSÚ, op. cit., p.143.

${ }^{121}$ ROXIN, Claus. Derecho Penal, parte general, tomo I. Fundamentos. La estructura de la teoria del delito. Madrid: Civitas, 1999, p.137
} 
do próprio direito penal, que na sua ânsia em obter respostas e vitória em julgamentos pode levar a uma perseguição de caráter punitivo e vingativo ao indivíduo, passando por cima de preceitos constitucionais e direitos inalienáveis do indivíduo, a fim de obter resultados.

O princípio da reserva legal existe desde a Roma Antiga. Sobre o tema, Nelson Hungria dizia que a aplicação da lei penal inicialmente foi caracterizada pela analogia, sendo posteriormente substituída pela submissão à lei. ${ }^{122}$

Na Idade Média houve uma prevalência do direito costumeiro ou arbítrio judicial $^{123}$, sendo a existência de antecedentes jurídicos bastante empregados. Talvez o mais famoso da época, e ainda bastante reconhecido, seja a Magna Carta do Rei João Sem Terra, que em seu art.39 estabelece o seguinte:

"Nenhum homem livre será levado ou preso ou retirado ou posto fora da lei ou exilado ou de qualquer maneira prejudicado, ou nós não iremos ou enviaremos contra ele, exceto em decorrência de um julgamento justo por seus pares ou pela lei da terra." ${ }^{124}$

Constitui a Magna Carta, então, uma importante fonte histórica quanto à limitação aos poderes estatais em favor da liberdade individual, relacionando essa limitação à existência de uma lei anterior. ${ }^{125}$

O tema foi evoluindo ao longo dos séculos, participando para o seu progresso autores como Locke, Rousseau e Montesquieu. A maior contribuição para o tema, entretanto, veio de Cesare Beccaria, que em seu Dos delitos e das penas trouxe à tona o conceito de que o juiz não poderia formar o direito penal ou que as normas incriminadoras pudessem decorrer dos costumes, senão apenas da lei. Sobre o tema, ele dicorre:

\footnotetext{
${ }^{122}$ HUNGRIA, Nelson. Op.cit., p.27.

${ }^{123}$ ROXIN, Claus. Op. cit., p.141

${ }^{124}$ HOLT, James Clarke. Magna Carta. $2^{\mathrm{a} e d .}$., Cambridge: Cambrisge University Press, 1995, p. $460 / 461$

${ }^{125}$ NILO, Batista. Introdução crítica ao direito penal brasileiro. $3^{\mathrm{a} e d ., ~ R i o ~ d e ~ J a n e i r o: ~ R e v a n, ~}$ 1996, p.65
} 
"Nada é mais perigoso do que o axioma comum de que é necessário consultar o espírito da lei. Este é um dique aberto à torrente de opiniões. Esta verdade, que parece paradoxal às mentes vulgares, mais abaladas por pequenas desordens presentes do que pelas funestas, mas remotas, consequiências que nascem de um falso princípio radicado numa nação, parece-me demonstrado. (...) O espírito da lei seria, então, o resultado da boa ou má lógica de um juiz; de uma fácil ou difícil digestão; dependeria da violência de suas paixões, da fraqueza de quem sofre, das relações do juiz com a vítima e de todas as mínimas forças que alteram as aparências de cada objeto no espírito indeciso do homem." 126

O Princípio da reserva legal foi posteriormente enfatizado na Bill of Rights $^{127}$ inglesa (1689. A proibição de leis com efeitos retroativos de fato ocorreu na Declaração do Bom Povo da Virgínia (1776), sendo posteriormente incorporado na Constituição dos EUA (1787). Posteriormente, tal proibição chegou à Europa, com o Código Penal Austríaco (1787) e a Declaração dos Direitos do Homem e do Cidadão, em 1789. Em 1793, a Constituição da França qualificou como criminoso o efeito punitivo da lei penal não favorável ao réu.

Veio do Código Penal da Baviera, de 1813, a famosa expressão que definiria o princípio da reserva legal: "nullum crimen nulla poena sige lege”. ${ }^{128}$ Von Feuerbach, autor do código, afirmava que a justificativa da punição decorria do fato de que alguém, embora conhecendo a ameaça, não deixasse de praticar conduta proibida. Assim, a punibilidade de determinado fato estaria diretamente condicionada à anterioridade de sua incriminação e da prévia cominação de pena, no texto de uma lei previamente publicada. ${ }^{129}$

O princípio da reserva legal, desde então, passou a ser incorporado em praticamente todas as constituições democráticas. No Brasil, foi incorporado em todas as Constituições e códigos penais, desde o

\footnotetext{
${ }^{126}$ BECCARIA, Cesare. Dos delitos e das penas. 2aed.,São Paulo: RT, 1997, p.33

${ }^{127}$ http://www.dhnet.org.br/direitos/anthist/decbill.htm (acessado em 17/10/2010)

${ }^{128}$ http://www.clubjus.com.br/?artigos\&ver=22204.32488 (acessado em 17/10/2010)

${ }^{129}$ BACIGALUPO, Felipe. Principios de derecho penal: parte general. $5^{\mathrm{a} e d ., ~ M a d r i d: ~ A k a l, ~ 1998, ~}$ p.55
} 
Império. ${ }^{130}$ As exceções mais acentuadas no século $\mathrm{XX}$ foram, por óbvias razões, as constituições da Alemanha de 1935 e Soviética de 1917; com a queda de ambos os regimes, o princípio passou a vigorar outra vez nas novas constituições.

Distinguem-se tradicionalmente quatro consequiências do princípio da reserva legal ${ }^{131}$ : as proibições da analogia (nullum crimen, nulla poena sine lege stricta), do direito consuetudinário para fundamentar ou agravar a pena (nullum crimen, nulla poena sine lege scripta), da retroatividade da lei penal (nullum crimen, nulla poena sine lege praevia) e da existência de incriminações vagas e indeterminadas (nullum crimen nulla poena sine lege certa $)^{132}$.

Sobre a legalidade, Ferrajoli afirma que é essencial para o próprio Estado democrático de direito, tornando-se, por isso, dogma que não deve ser afastado sob qualquer hipótese. ${ }^{133}$

Isso é importante para se fazer uma análise deste princípio sob a luz dos acontecimentos dos tribunais militares ocorridos logo após o término da $2^{a}$ Guerra Mundial e os tribunais ad hoc de Iugoslávia e Ruanda.

Bassiouni $^{134}$ sustenta que no direito internacional o princípio da reserva legal não pode ser aplicado no mesmo sentido estreito em que é aplicado no direito interno; isso se deve, pois, os crimes contra a paz já estarem previstos no direito internacional antes da aprovação dos tribunais, através dos pactos de Briand-Kellog e Ribbentrop-Molotov, dentre outros. Com relação aos crimes contra a humanidade e de guerra, estes já estariam

\footnotetext{
${ }^{130}$ ROXIN, Claus. Op.cit., p. 143

${ }^{131}$ GOMES, Luiz Flávio. Sobre a garantia da legalidade em direito penal. In: O sistema interamericano de proteção dos direitos humanos. São Paulo: RT, 2000, p.302/306

${ }^{132}$ COSTA, Rodrigo de Souza. Terrorismo: uma abordagem crítica. In: Revista de Ciências Jurídicas. Vol.1, n, Rio de Janeiro: ICJ/UVA, 2002, p.194.

${ }^{133}$ FERRAJOLI, Luigi. Derecho y razón. Teoria del garantismo penal. 5 aed.; Madrid: Trotta, 2001, p.857.

${ }^{134}$ BASSIOUNI, M. Cherif. Crimes against humanity in international criminal Law. $2^{\mathrm{a}}$ ed., Haia: Klwer, 1999, p.129/130.
} 
codificados pelas legislações internas, antes mesmo do término da $2^{\text {a }}$ Guerra Mundial, nas Convenções de Haia e Genebra.

Adentrando no tema, Gil Gil ${ }^{135}$ afirma que, embora os documentos internacionais não contivessem sanções explícitas nem penas às violações que viessem a ocorrer, houve uma condenação moral pelas nações envolvidas no conflito mais sangrento da História, conferindo, então, legalidade aos tribunais; para ele, foi preciso, então, uma nova interpretação do princípio da legalidade, já que existiam razões morais e de utilidade internacional que superariam o rigor técnico do princípio.

Sua posição, no entanto, encontra opositores. Embora não concorde com a visão de Gil Gil, Glaser ${ }^{136}$ sustenta que embora o direito internacional devesse se ajustar ao princípio da legalidade, não pode servir de proteção contra condenações injustas, ou seja, não poder ser responsabilizado pelo fracasso do direito e a subtração dos culpados do julgamento.

Quintano Ripollés ${ }^{137}$ afirmou que o princípio da legalidade não seria aplicável no direito internacional. Sustentou, entretanto, que a inaplicabilidade da reserva legal ao direito penal internacional deveria ser corrigida através de uma codificação sobre tal direito; isso de fato ocorreu, com o advento do Estatuto de Roma.

Huet e Koering-Joulin, ${ }^{138}$ em seu livro conjunto, afirmam que as cortes formadas para julgar os criminosos de guerra em Europa e Japão não estavam criando um direito (assim, não estariam ferindo o princípio em questão), mas apenas estariam aplicando um já existente. Afirmaram que o

\footnotetext{
${ }^{135}$ GIL, Gil. Derecho penal internacional, p.67

${ }^{136}$ GLASER, Stefan. Infraction internationale: sés élements constituifs et ses aspects juridfiques. Paris: Librairie Génerale de Droit et de Jurisprudence, 1957, p.41 e ss.

${ }^{137}$ RIPOLLÉS, Antonio Quintano. Tratado de derecho penal internacional e internacional penal. Tomo I, Madrid: Consejo Superior de Investigaciones Científicas, Instituto "Francisco de Vitoria", 1995, p.95.

${ }^{138}$ HUET, KOERING-JOULIN, op.cit., p.56/57.
} 
princípio da reserva legal expressa um princípio de justiça, sendo que maior seria a injustiça se os criminosos de guerra não viessem a responder pelos delitos internacionais que praticaram.

Para pôr uma pá de cal sobre o tema, o ICTY afirmou, no polêmico caso Dusko Tardic ${ }^{139}$, que o princípio da reserva legal deve proteger apenas as pessoas de serem castigadas por atos que o agente achava ser lícito no momento em que o praticou; no caso em tela, o acusado tinha plena ciência das ilegalidades que estava cometendo, tanto pelo direito costumeiro, quanto o direito da extinta Iugoslávia.

Posteriormente aos tribunais militares, o princípio da reserva legal foi reconhecido em diversos tratados, tais como a Declaração Universal dos Direitos do Homem, a Convenção Internacional sobre os Direitos Civis e Políticos, e o próprio Estatuto de Roma (arts. 22,23 e 24) ${ }^{140}$, dentre outros.

Para concluir sobre o tema, ressalta Bassiouni:

"De outra maneira, deve ser, ainda uma vez, reiterado, que a reserva legal é essencial ao próximo sistema penal, em particular, se se pretender ser garantista, como, aliás, é a lógica do Tribunal Penal Internacional. Assim, o princípio da legalidade é indispensável à nova jurisdição penal internacional que se desenha e, para que esta possa atingir as finalidades desejadas, faz-se necessário que este seja aprofundado.

(...) Direito penal internacional e legalidade, pois, não são incompatíveis, não podendo se sustentar os argumentos favoráveis ao costume. Espera-se que essa formalização decorrente das regras determinadas na capital italiana reduza as incertezas e aproxime, neste particular, as exigências do direito interno $\mathrm{e}$ as do direito internacional." ${ }^{141}$

\subsection{Complementaridade}

O último princípio fundamental foi estabelecido pelo Estatuto de Roma, com o intuito político de obter o maior número de adesões possíveis.

\footnotetext{
${ }^{139}$ Decision on the Defence Motion on Jurisdiction, Prosecutor v. Tadic, Case n ${ }^{\circ}$ IT-94-1-T,T. Ch.II, 10 august 1995 / http://www.icty.org (acessado em 17/10/2010)

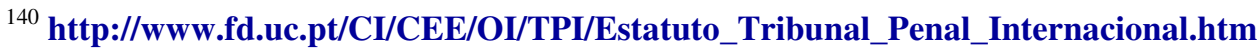
(acessado em 17/10/2010)

${ }^{141}$ BASSIOUNI, op. cit. , p.157/158.
} 
Tal princípio existe sobre a afirmação de que os atos criminosos praticados, de interesse internacional, deverão ser julgados pelo TPI, levando em conta, porém, que os Estados envolvidos nos atos dispõem de poder judiciário organizado próprio. Quando da organização do Estatuto de Roma, portanto, deveria ter sido dada a primazia de jurisdição para o TPI ou para a jurisdição nacional envolvida; como o Estatuto fora redigido com o referido intuito, a primazia do direito foi dada, infelizmente, à jurisdição nacional. ${ }^{142}$

Assim, tendo sido dada a primazia de direito para a jurisdição nacional fala-se que, em relação ao TPI, prevalece o princípio da complementaridade, onde estará legitimada o órgão internacional apenas quando o órgão nacional dispuser de seu direito ou exercê-lo com inércia, incompetência ou corrupção.

Celso de Albuquerque Mello afirmava que o princípio predominante nas legislações internas, o da territorialidade, seria aquele relacionado com a idéia de soberania estatal. Sustentava também que o princípio da competência universal representa a ordem jurídica internacional, devendo, por isso, predominar sobre o outro princípio. ${ }^{143}$

João Mestieri, por sua vez, afirma que "o fundamento desta teoria (competência universal) é ser o crime universal, e por isso todos os Estados têm interesse em coibir a sua prática e proteger os bens jurídicos da lesão provocada pela infração penal."

O princípio tem por meta, então, evitar que ocorra a impunidade, onde autores de ilícitos penais permanecessem impunes, pelo simples fato de que foram protegidos pelo princípio da territorialidade, uma vez que este

\footnotetext{
${ }^{142}$ BASSIOUNI, M. Cherif. Note explicative sur Le Statut de la Cour Pénale Internationale ratification et mise en oeuvre dans les legislations nationals - Révue international de droit penal. Toulouse:Érès, 2000, p.4, nota 14)

${ }^{143}$ MELLO, Celso de Albuquerque. Direito Penal e direito internacional, Rio de Janeiro. Ed Renovar,p.35.

${ }^{144}$ MESTIERI, João. Teoria elementar do direito criminal, parte geral. Rio de Janeiro: Editora do autor, 1990, p.117
} 
princípio por si só não é suficientemente forte para evitar a aplicação do direito penal.

No caso brasileiro, o princípio da complementaridade cede espaço para a primazia da legislação brasileira, como se pode ver no art. $7^{\circ}$, II, a, do $\mathrm{CP}$, que afirma que ficam sujeitos à lei brasileira, mesmo tendo sido cometidos no estrangeiro, os crimes que por tratado ou convenção o Brasil se obrigou a reprimir. Sobre o tema, Celso de Albuquerque Mello ${ }^{145}$ exprime seu desagrado com a posição brasileira para com esse artigo do código penal. Afirma ele que os crimes internacionais deveriam ser sempre reprimidos, independentemente da existência ou não de documento internacional que o proíba, ou ainda que se tenha ratificado-o, dada a força do costume para o direito penal internacional.

O princípio da universalidade do direito de punir faz-se sempre necessário para se evitar que autores de crimes previstos pelo TPI encontrem abrigo em qualquer lugar, já que reduz tal possibilidade, que se baseia na soberania estatal. Como exposto previamente, o próprio conceito de soberania modificou-se ao longo do século passado, encontrando novas maneiras de se justificar no século XXI, dentre elas a cooperação jurídica entre os Estados; daí não se dever mais alegar a soberania estatal para acobertar a impunidade, que seria muito mal vista internacionalmente, repercutindo pessimamente para o Estado que o fizesse.

A primazia do direito internacional sobre o nacional, tão presente nos tribunais ad hoc, por exemplo, não encontrou guarida. Talvez o caso mais emblemático sobre o tema, como referido previamente, tenha sido o do julgamento de Dusko Tadic, agente de polícia servo-bósnio, preso na Alemanha por autoridades germânicas, transferido para Haia, local onde as acusações seriam menos pesadas que onde fora originalmente preso. Ao chegar em Haia, Tadic questionou a autoridade do ICTY, alegando estar sendo violada a soberania iugoslava. O ICTY rejeitou a pretensão do réu,

${ }^{145}$ MELLO, op. cit., p.34 
alegando que caso não prevalecesse a jurisdição internacional, os crimes internacionais estariam sendo equiparados a crimes comuns. Pela própria gravidade dos crimes julgados pelo ICTY, ter-se-iam por violados bens universais, protegidos pelo ICTY, daí então advindo sua competência para julgar. ${ }^{146}$ Discussão semelhante ocorreu no ICTR.

A primazia fora consequiência direta da forma como os tribunais ad hoc foram criados, pelo Conselho de Segurança, com objetivos claros de assegurar a paz, com força e poder de decisão do Conselho de Segurança por trás. Por isso mesmo, teve primazia sobre o direito nacional envolvido; foram criados pela força, impostos pelo Conselho de Segurança da ONU sobre os acusados nacionais. São tribunais com características predominantemente políticas.

Ao contrário do ICTR e do ICTY, o TPI passou por um processo de elaboração totalmente distinto. Por se tratar de um organismo permanente, fez-se sumamente importante que o mesmo se legitimasse através de um alto número de ratificações ao tratado que lhe conferiu vida, o Estatuto de Roma. Desde os primeiros dias de elaboração do Estatuto, não houve consenso (ao contrário dos tribunais ad hoc, impostos sem oposição dentro do Conselho de Segurança), principalmente entre os membros permanentes do Conselho de Segurança da ONU e um grupo de países atuantes no cenário político internacional, chamados de "like-minded"147. Um grupo desejava um TPI mais conservador quanto às suas prerrogativas; o outro queria um TPI mais atuante e com rol de competências ampliado.

Acabou se criando um tribunal "meio-termo", fruto de um consenso diplomático entre os Estados signatários. Talvez o tópico mais delicado de sua questão, a prevalência da primazia ou complementaridade jurisdicional, foi resolvida no art.17 do Estatuto de Roma ${ }^{148}$.

\footnotetext{
${ }^{146}$ Sobre o tema, ver nota de rodapé $\mathrm{n}^{\circ} 149$.

${ }^{147}$ MAIA, Marrielle, op. cit., p.77.

${ }^{148}$ http://www.fd.uc.pt/CI/CEE/OI/TPI/Estatuto_Tribunal_Penal_Internacional.htm (acessado em 18/10/2010)
} 
Sobre o artigo, Carlos Eduardo Adriano Japiassú disserta:

"Conforme disposto neste dispositivo convencional, existe uma presunção relativa em favor dos Estados nacionais, que serão aqueles que, em um primeiro momento, estarão legitimados para agir, em caso de prática de algum crime previsto no Estatuto. Esta presunção poderá ser superada sempre que constatado, mediante o exercício da fiscalização das autoridades judiciárias internas - função inerente à Corte -, não se terá, nacionalmente, interesse ou possibilidade de fazê-lo.

(...) no que diz respeito à falta de disposição e à incapacidade, deve-se mencionar a idéia de coisa julgada. Se for decorrente de decisão emanada do Tribunal Penal Internacional, essa gerará efeitos ex tunc. O mesmo não pode se dizer da decisão de um tribunal nacional, desde que seja verificado que houve uma marcada intenção de subtrair o acusado de um efetivo e justo julgamento, o que permitirá que o Tribunal possa iniciar um procedimento." 149

Marrielle Maia afirma que o princípio da complementaridade consiste na consagração da idéia, ainda não formalizada, da existência de uma obrigação de processar e julgar, internamente, as violações do direito penal internacional e do direito internacional humanitário. ${ }^{150}$

Outro problema decorrente da adesão do TPI ao princípio da complementaridade é o de que, criado com o intuito de evitar que violadores de direitos humanos restem impunes, caberá ao TPI um papel de crítico das jurisdições nacionais com relação aos andamentos dos casos, já que caberá a elas, preferencialmente, lidar com esses criminosos; isso poderia gerar atritos entre o próprio TPI e os Estados em questão, já que poderá criar uma intromissão indesejada do TPI na jurisdição (e, portanto, soberania) nacional por um lado, e por outro, uma menor efetivação da proteção internacional aos direitos humanos.

\footnotetext{
${ }^{149}$ JAPIASSÚ, op. cit. p.171/172.

${ }^{150}$ Maia, op. cit. p.80.
} 


\section{Os crimes previstos pelo Estatuto de Roma}

O TPI é competente para julgar, com caráter permanente e independente, os crimes mais graves e repudiados pela sociedade internacional. São estes crimes, como referido anteriormente, os de genocídio, crimes contra a humanidade, crimes de guerra e crimes de agressão.

Desde a criação do Tribunal de Nuremberg até a efetiva criação do TPI foram-se mais de 50 anos de evolução em torno do diálogo da cooperação internacional e da criação de um tribunal penal internacional permanente. Desde então, mais de 25 crimes foram enunciados, possíveis candidatos à tutela internacional $^{151}$.

Dentre esses 25 crimes, a Comissão de Direito Internacional, elaborando o Anteprojeto do Estatuto de Roma, reconheceu a existência de dois tipos de crimes. A primeira destina-se ao genocídio, agressão, violação de leis e costumes aplicados em conflitos armados e crimes contra a humanidade. A segunda categoria pertence aos crimes definidos em tratados internacionais, tais como as infrações graves previstas pela Convenção de Genebra, apartheid, tortura, terrorismo e tráfico ilícito de entorpecentes.

Com a preocupação em se assegurar o maior número de adesões possíveis ao Estatuto de Roma, este foi redigido com o intuito de limitar a competência do TPI.

Nisso, as categorias elaboradas no anteprojeto subiram de duas para três. A primeira incluía crimes de aceitação unânime (genocídio, crimes contra a humanidade e crimes de guerra); a segunda incluía apenas o crime de agressão, que foi contestado por muitos dos Estados representados, por questões políticas; a terceira categoria incluía os crimes descritos em

${ }^{151}$ BASSIOUNI, Le fonti e Il contenuto del diritto penale Internazionale, p. 104/105 
tratados internacionais (entre eles, os de tráfico de drogas e terrorismo), que foram seriamente questionados quanto à viabilidade de sua inclusão no tratado. Posteriormente, no Ato Final da Conferência de Roma os crimes previstos em tratados internacionais foram reconhecidos como sendo de extrema gravidade e propensos à, um dia, fazerem parte do rol de crimes de competência do TPI ${ }^{152}$; já o crime de agressão, apesar de ter sido mantido sob competência do TPI, teve sua definição (motivo de divergência entre os Estados) postergada.

A competência para julgar tais crimes, entretanto, só se manifesta em relação aqueles perpetrados após a vigência do Estatuto de Roma. Assim, os crimes cometidos antes da entrada em vigor do Estatuto saem da alçada de competência do Tribunal. Pior, se um Estado se torna parte do Estatuto após a sua vigência, o TPI só terá competência para julgar os crimes a ele relacionados depois da entrada em vigor do Estatuto nesse Estado ${ }^{153}$, salvo se ele aceitar a competência do TPI para julgar violações prévias à sua entrada no Estatuto.

\subsection{Crime de Genocídio}

Autores como Vitoria, Grotius e Suárez, considerando o ius ad bellum e a doutrina da intervenção humanitária, contribuíram para uma base na qual a punição ao genocídio se justificaria; para Vitoria, a base filosófica para a qualificação de uma guerra como justa seria a concepção de soberania limitada por princípios ético-jurídicos decorrentes da Lei natural. ${ }^{154}$ Apesar disso, sua contribuição restringe-se apenas ao chamado "direito da guerra".

\footnotetext{
${ }^{152}$ MAIA, op.cit., p.86.

${ }^{153}$ MAZZUOLI, op.cit., p. 54

${ }^{154}$ GIL GIL, Derecho penal internacional, p.106
} 
O termo "crimes contra a humanidade" existe desde a Convenção de Haia de 1907, onde, através da Cláusula Martens ${ }^{155}$, consolidou-se o entendimento de que "a ausência de convenção não significaria ausência de um direito de guerra", ${ }^{156}$ donde se concluía que para aquilo que não tiver sido tratado pela Convenção tanto a população civil quanto os militares estariam protegido pelo Direito das Gentes, utilizado pelas "nações civilizadas, leis da humanidade e exigências da consciência pública". ${ }^{157}$ Mas, em efetivo, apesar de referências anteriores ao crime (ex.: A expressão "lesa-humanidade foi adotada em 1915 pela comissão responsável por levar à justiça os autores do assassínio de um milhão de armênios, no extinto Império Turco-Otomano; o termo "genocídio" apareceu por primeira vez em 1944, na obra "Axis rule in occupied Europe", de Rafael Lemkin ${ }^{158}$, onde descreveu os crimes cometidos pelo nazismo.), o genocídio como categoria de crimes apenas surgiu em 1945, com o Tribunal de Nuremberg.

Posteriormente a Nuremberg, por força da resolução $260-\mathrm{A}^{159}$ da Assembléia Geral da ONU, em 1948, na Convenção sobre a Prevenção e a Repressão do Crime de Genocídio, chegou-se ao entendimento de que o crime de genocídio trata-se de um crime internacional e a mais grave violação de crimes contra a humanidade possível. ${ }^{160}$ No Brasil tal Convenção foi aprovado pelo Decreto Legislativo n 30822, de 11/04/1951, adentrando ao direito interno brasileiro com status de norma constitucional.

A Corte Internacional de Justiça, em 1951, consolidou o entendimento de que o crime de genocídio teria caráter de norma

\footnotetext{
${ }^{155}$ http://www.icrc.org/web/spa/sitespa0.nsf/html/5TDLCY (acessado em 20/10/2010)

${ }^{156}$ LOMBOIS, Claude. Droit Pénal International, p. 41.

${ }^{157}$ GIL GIL, op.cit., p. 107

${ }^{158}$ http://www.preventgenocide.org/lemkin/AxisRule1944-1.htm (acessado em 20/10/2010)

${ }^{159}$ http://www.dhnet.org.br/direitos/sip/onu/genocidio/conv48.htm (acessado em 20/10/2010)

${ }^{160}$ SCHABAS, William A. An introduction to the International Criminal Court, p.30
} 
costumeira na sociedade internacional. Afora isso, reconheceu tal crime como sendo de direito internacional. ${ }^{161}$

No Estatuto de Roma, o crime de genocídio encontra-se codificado no art. $6^{\circ}$, como transcrito abaixo:

"Crime de genocídio

Para os efeitos do presente Estatuto, entende-se por «genocídio» qualquer um dos actos que a seguir se enumeram, praticado com intenção de destruir, no todo ou em parte, um grupo nacional, étnico, rácico ou religioso, enquanto tal:

a)Homicídio de membros do grupo;

b)Ofensas graves à integridade física ou mental de membros do grupo;

c)Sujeição intencional do grupo a condições de vida pensadas para provocar a sua destruição física, total ou parcial;

d)Imposição de medidas destinadas a impedir nascimentos no seio do grupo;

e)Transferência, à força, de crianças do grupo para outro grupo."

A consagração do crime de genocídio, pelo Estatuto de Roma, não por acaso, ocorreu exatos cinqüenta anos após o início da Convenção sobre a Prevenção e a Repressão do Crime de Genocídio, em comemoração aos avanços da humanidade na luta contra essa que é a mais bárbara violação de direitos humanos. Mas ainda há muito a ser feito.

\subsection{Crimes Contra a Humanidade}

Os crimes contra a humanidade foram intensamente discutidos na Conferência de Roma, pois ao contrário da discussão em torno dos crimes de genocídio, este não era de fácil definição. Como resultado, tal modalidade de crime passou pelo Estatuto sem ser definido, passando, ainda hoje, sem ser definido em outros tratados internacionais. ${ }^{162}$

\footnotetext{
${ }^{161}$ JARDIM, Tarciso Dal Maso. O Tribunal Penal Internacional e sua importância para os direitos humanos, p.22, nota $\mathrm{n}^{\circ} 18$.

${ }^{162}$ BOURDON, William. La Cour Pénale Internationale. Paris: Éditions su Seuil, 2000.
} 
Apesar de não terem sido definidos, existe um consenso internacional no que se refere ao seu teor, que poderia ser explicado como sendo "quaisquer atrocidades e violações de direitos humanos perpetrados no Planeta em larga escala, para cuja punição é possível aplicar-se o princípio da jurisdição universal". ${ }^{163}$

Sua origem como crime repudiado internacionalmente encontra-se no massacre turco contra civis armênios em 1915, também posteriormente reconhecido como genocídio por diversas entidades internacionais (ver nota de rodapé $\left.n^{\circ} 173\right)$.

Entretanto, sua efetiva menção ocorreu no término da $2^{\mathrm{a}}$ Guerra Mundial, em decorrência, principalmente, do Holocausto efetuado pelo Estado nazista. Isso se deve, segundo Alessandra Palma, porque essa "nova categoria se fazia necessária em virtude da impossibilidade de reconduzir tais crimes à categoria dos crimes de guerra e contra a paz, já conhecidos". 164

No Tribunal de Nuremberg tais crimes ganharam definição, no art. $6^{\circ}$ do Estatuto, que os define como sendo, dentre outros, o assassinato, o extermínio, escravização, deportação e outros atos inumanos cometidos contra a população civil antes da guerra ou durante a mesma, bem como a perseguição por motivos políticos, raciais ou religiosos, constituindo ou não uma vulneração da legislação interna do país onde foram perpetrados.

Outra característica dos crimes contra a humanidade é o de que "para serem considerados como tais, esses deveriam ser conexos aos crimes de guerra e contra a paz", o que faz deles "complementares em relação às

\footnotetext{
${ }^{163}$ MAZZUOLI, op. cit., p. 58.

${ }^{164}$ PALMA, op.cit., p. 9
} 
outras duas figuras criminosas e não eram considerados suscetíveis de uma relevância internacional autônoma". 165

Evoluiu a noção de crimes contra a humanidade a partir do Estatuto de Roma $\left(\operatorname{art} .7^{\circ}\right)$ principalmente em relação aos crimes sexuais cometidos contra mulheres e crianças, não previstos nos Tribunais militares e ad hoc, por exemplo. ${ }^{166}$

\subsection{Crimes de Guerra}

A guerra foi, por largo período da história, considerada, juridicamente falando, legal. Sobre o tema, Celso de Albuquerque Mello ${ }^{167}$ diz que o próprio direito internacional teria surgido "essencialmente como um direito de guerra".

Registros históricos citam exemplos de preocupação em se estabelecer regras limitadoras em relação à guerra. Sun Tzu ${ }^{168}$ descreve, no século IV a.C. o costume de se excluir das guerras os velhos, feridos, crianças e mulheres; o Código de Manu foi um dos primeiros a impor regras à guerra, em seu livro VII ${ }^{169}$; soldados atenienses foram julgados por lacedemônios por terem destruído sua esquadra, na Grécia Antiga; a "Paz de Deus", norma costumeira sobre a conduta em guerra, resultado de diversos pronunciamentos da Igreja na época, virou costume internacional na Idade Média, sendo tida por válida até hoje, dentre outros exemplos.

\footnotetext{
${ }^{165}$ PALMA, op. cit., p.10

${ }^{166}$ MAIA, op. cit., p. 88.

${ }^{167}$ MELLO, Celso de Albuquerque. Direito penal e direito internacional, p. 103.

${ }^{168}$ TZU, Sun. A arte da guerra. São Paulo: Ed ${ }^{\mathrm{a}}$. Cultura, 2000, p.17

${ }^{169}$ http://pt.wikipedia.org/wiki/C\%C3\%B3digo_de_Manu (acessado em 20/10/2010)
} 
O movimento para se qualificar a guerra como ilegal começa no século XIX. Suas principais manifestações ocorrem na Convenção de Genebra e Convenção de Haia, passando por diversas outras convenções e tratados internacionais como tema em foco.

Em termos de atualidade, o cenário muda a partir de 1945, quando a guerra ganha status jurídico de ilicitude. O Tribunal de Nuremberg reconhece tais crimes como sérias violações aos costumes e às regras internacionais. Daí então poder-se dizer que houve efetiva internacionalização do tratamento desses crimes, já que historicamente o direito continental europeu, principal motor das mudanças no ordenamento jurídico internacional, considerava as condutas tidas como crimes de guerra como sendo tuteladas pelo direito interno. Desde então adota-se a visão anglo-saxônica sobre o assunto, que reconhece a necessidade de se reprimir as condutas belicosas e crimes decorrentes através de normas de direito internacional. ${ }^{170}$

Nas negociações ocorridas em volta do Anteprojeto do Estatuto de Roma a pressão política do grupo contrário a retrocessos na proteção dos direitos humanitários (o chamado grupo "like-minded") surtiu efeitos, por incorporar também na classificação de crimes de guerras aqueles ocorridos em conflito interno. Entretanto, adotaram-se medidas a fim de "defender o direito dos Estados de manter a ordem interna e defender a soberania e ordem interna do país", reduzindo o plano de atuação do TPI, concernente ao tema, apenas a "crimes perpetrados como parte de um plano ou política". ${ }^{171}$

Sob o alto teor política acerca da definição do tema, Marrielle Maia disserta:

\footnotetext{
${ }^{170}$ GIL GIL. El genocídio y otros crímenes internacionales, p.86

${ }^{171}$ SCHEFFER, David J.. The United States and the International Criminal Court. 93 American Journal of International Law, p.20.
} 
"Sem dúvida, algumas das questões mais sensíveis negociadas em Roma estavam relacionadas a este tema, uma vez que abrangem a conduta de operações militares, inclusive a proibição do emprego de armas, e envolvem a possibilidade de incriminação de pessoal subordinado às forças armadas." 172

Mesmo assim houve progresso na negociação em volta do Estatuto, ao se sistematizar e ampliar o conteúdo geral daquilo que se é tido por crimes de guerra (art. $8^{\circ}$ do Estatuto de Roma).

\subsection{Crime de Agressão}

De todos os crimes de competência do TPI, este é de longe o mais difícil de ser conceituado, mesmo antes da declaração de ilicitude da guerra.

No plano internacional a guerra foi declarada um meio ilícito de solução de controvérsia (arts. $2^{\circ}$ e $4^{\circ}$ da Carta das Nações Unidas e Pacto de Briand-Kelogg de renúncia à guerra).

A não existência de uma definição exata de agressão no cenário internacional, que levasse, por conseqüência, a uma definição de crime de agressão que fundamentasse a responsabilidade penal internacional dos indivíduos dificultou a entrada dessa modalidade de crime no Estatuto de Roma. ${ }^{173}$

A primeira manifestação, no cenário internacional, da noção de crime de agressão, surgiu no Tratado de Versalhes, de 1918. Em seu art. 227 ficaria instituído um tribunal para julgar o ex-Kaiser da Alemanha, Guilherme II, acusado de "ofensa suprema à moralidade internacional e à autoridade dos tratados" ${ }^{, 174} \mathrm{O}$ Kaiser exilou-se na Holanda, de onde nunca

\footnotetext{
${ }^{172}$ MAIA, op. cit., p. 90

${ }^{173}$ MAZZUOLI, op. cit., p. 65

${ }^{174}$ http://jus.uol.com.br/revista/texto/14525/a-criacao-de-um-tribunal-penal-internacional (acessado em 21/10/2010)
} 
veio a ser julgado, tendo o governo holandês se negado a cumprir as exigências dos países aliados em se levasse o monarca a julgamento, sob a alegação (dentre outras), hoje vista como atrasada, de que os indivíduos não podem ser vistos como sujeitos na ordem internacional, pois são os Estados que atuam na política externa. A partir de Nuremberg tal afirmação foi rechaçada para não mais ser aceita como óbice ao julgamento de indivíduos por violações de direitos humanos. Já o Estatuto de Roma, por sua vez, aboliu a imunidade de jurisdição para chefes de Estado (art.27). ${ }^{175}$

O crime de agressão foi codificado nos tribunais militares de Nuremberg $\left(\operatorname{art} .6^{\circ}\right)$ e Tóquio (art. $5^{\circ}$ ), não tendo sido reconhecido nos tribunais ad hoc para Ruanda e Iugoslávia. Nesse período que vai do término da $2^{\mathrm{a}}$ Guerra Mundial até a elaboração do Estatuto de Roma o chamado crime de agressão somente foi definido uma vez, na Resolução 3314 (XXIX) da Assembléia Geral da $\mathrm{ONU}^{176}$, não sendo, entretanto, utilizado.

Seguindo a linha de dificuldade em se conceituar o crime, o Estatuto de Roma desagradou a muitos, já que fora acordado que o Estatuto inseriria o crime de agressão no rol de competência do TPI (art. $5^{\circ}$ ), postergando, porém, sua definição. ${ }^{177}$ A Comissão se reuniu em 1999 para definir os termos de conceituação do crime de agressão, o que não logrou efeito. Hoje, apesar de ser de competência do TPI, o crime mencionado encontra-se

\footnotetext{
${ }^{175}$ MAZZUOLI, op. cit., p.67.

176

http://www.cedin.com.br/site/pdf/legislacao/pdf_tratados6/Resolu\%E7\%E3o\% 203314\%20 $\% 28 X X I X \% 29 \% 20 \mathrm{da} \% 20 \mathrm{AG} \% 20 \mathrm{da} \% 200 \mathrm{NU} \% 20$ -

\%20Defini\%E7\%E3o\% 20de\% 20Agress \% E3o.pdf (acessado em 21/10/2010)

${ }^{177}$ Segunda a Comissão Preparatória do Estatuto, “o exercício da jurisdição do TPI estará condicionado à aprovação de uma emenda ao Estatuto, isolada ou no contexto de uma conferência de revisão, que contenha a definição do referido crime e estabeleça o papel a ser desempenhado pelo Conselho de Segurança."
} 
numa posição nebulosa de competência mista entre o TPI e o Conselho de Segurança, a quem caberia, a princípio, conceituar o crime em si. ${ }^{178}$

${ }^{178}$ MAIA, op. cit., p. 95 


\section{A incorporação do Estatuto de Roma ao Ordenamento Jurídico Brasileiro}

Muitas foram as dificuldades enfrentadas nos diálogos envolvendo a elaboração do Estatuto de Roma para a criação do TPI. Parte considerável delas se manifesta na evidente disparidade e diferenças entre os inúmeros sistemas jurídicos adotados pelos Estados que participaram da Conferência $^{179}$ (160 países participaram, sendo que 120 votaram a favor da criação do Tribunal).

Com relação aos crimes contra a administração da justiça, um grupo encabeçado pelo jurista Tarciso dal Maso Jardim ficou encarregado de adequar a legislação brasileira aos termos do Estatuto. Estabeleceu-se o caráter supletivo da justiça brasileira para julgar e processar os crimes contra a administração previstos pelo TPI, quando não julgados por ele.

Outras questões, entretanto, fazem-se mais presentes no questionamento da adequação da legislação brasileira ao Estatuto de Roma, cuja vigência já é realidade. $\mathrm{O}$ principal problema ocorre devido a pouca idade que possui o Tribunal, o que ainda não possibilitou uma discussão mais acalorada sobre o tema no país, haja vista que o próprio STF ainda não se manifestou sobre as alegadas questões de constitucionalidade e incompatibilidade da $\mathrm{CF}$ com o Estatuto. Os principais pontos serão elucidados a seguir.

\subsection{Imunidade Parlamentar}

O artigo 27 do Estatuto de Roma afasta qualquer hipótese de imunidade decorrente de lei interna ou internacional, mostrando ser ele

\footnotetext{
${ }^{179}$ TAQUARY, op. cit., p. 260
} 
mesmo aplicável a todos sem qualquer tipo de distinção, abarcando em sua jurisdição, inclusive, chefes de Estado e de governo.

O problema aparente aqui com a legislação brasileira é que a CF/88 garante imunidade parlamentar para que os membros do Congresso possam desempenhar seguramente as suas funções. A imunidade parlamentar, segundo a lei brasileira, divide-se entre absoluta (causa de exclusão de crime) e relativa (condição de não processabilidade); com relação à imunidade absoluta, pode-se dizer que se trata de uma "prerrogativa funcional de exclusão da ilicitude". ${ }^{180}$

Sob essa ótica, a imunidade parlamentar absoluta, prevista no art.53 da $\mathrm{CF} / 88$, possibilitaria a um membro do Congresso Nacional fazer, enquanto desempenhasse funções políticas, hipoteticamente falando, manifestações políticas que incitasse ao genocídio, sem ser por isso levado a julgamento a um Tribunal brasileiro, já que tratar-se-ia de inexistência de crime. ${ }^{181}$ Haveria então um choque entre a lei brasileira e o Estatuto de Roma, já que aos olhos do TPI teria ocorrido uma violação digna de ser levada a julgamento.

$\mathrm{O}$ artigo 27 do Estatuto exclui exatamente a possibilidade de que indivíduos, acobertados pelo status político que possuem, deixem de ser julgados pelos crimes que cometeram. Assim, posição oficial não é prerrogativa de imunidade sob os olhos do TPI, quando um indivíduo é acusado de violar um crime de sua competência.

\footnotetext{
${ }^{180}$ DOTTI, René Ariel. Curso de Direito Penal - Parte Geral. Rio de Janeiro: Forense, 2001, p. 283.

${ }^{181}$ JAPIASSÚ, Carlos Eduardo Adriano. Possibilidades e Desafios de Adequação do Estatuto de Roma à Ordem Constitucional Brasileira, in Tribunal Penal Internacional - Possibilidades e desafios, Rio de Janeiro, Ed ${ }^{\mathrm{a}}$. Lumen Iuris, p. 201.
} 
Quando postos em contraste, sob a perspectiva internacional ao qual o Brasil, na própria Constituição ${ }^{182}$, manifestou adesão, fica claro que, na hipotética situação introduzida, uma provável alegação de imunidade parlamentar não seria suficiente para livrar o político em questão da jurisdição do TPI. Não se poderia proteger a democracia numa situação dessas, acobertando um crime sob a égide da imunidade parlamentar, já que os crimes previstos no Estatuto não têm nenhuma relação óbvia com a imunidade parlamentar em si. Esta perde sua eficácia na medida em que o indivíduo que se valia dela na prerrogativa de político fere preceitos universalmente protegidos e espera, posteriormente, obter proteção dos estragos causados por sua manifestação equivocada de opinião.

\subsection{Entrega de Nacionais}

Os Estados signatários estão obrigados, pelo Estatuto, a cooperar totalmente com o TPI, em crimes que sejam de sua competência, seja durante a fase de investigação, seja na fase processual, conforme artigo 86 do referido Estatuto. A obrigação de cooperar, conforme disposto no pequeno artigo citado, é genérica, estendendo-se para todos os órgãos do Estado. Isso inclui, por exemplo, na criação de mecanismos por parte dos Estados a fim de acelerar a resposta destes aos requerimentos do TPI, bem como adequar a legislação interna aos termos do Estatuto, reconhecendo sua competência complementar para processar e julgar violadores de direitos humanos.

Uma dessas formas de cooperação manifesta-se no artigo 89 do Estatuto, qual seja, a entrega de indivíduos ao TPI, independentemente da

\footnotetext{
182 A Emenda Constitucional $n^{\circ} 45$, ao tratar da reforma do judiciário, previu no art. $5^{\circ}, \S$ $4^{\circ}$ da CF/88: "O Brasil se submete à jurisdição de Tribunal Penal Internacional a cuja criação tenha manifestado adesão."
} 
nacionalidade em questão. Este dispositivo, portanto, estaria em possível oposição ao disposto na CF/88, no seu art. $5^{\circ}$, LI, que impossibilita a extradição de brasileiros.

A entrega de uma pessoa ao TPI é um instituto jurídico sui generis nas relações internacionais contemporâneas, distinto do instituto da extradição, onde duas potências estrangeiras atuam em interesse mútuo, visando também a repressão internacional de delitos. ${ }^{183}$

Portanto, o Estatuto de Roma, visando evitar quaisquer problemas de inconstitucionalidade por parte de seus Estados, distinguiu claramente, no seu artigo 102, a modalidade extradição da modalidade entrega. ${ }^{184}$ Assim entende o Estatuto por "entrega" o ato de um Estado entregar uma pessoa ao TPI nos termos do Estatuto, reconhecendo por "extradição" a entrega de uma pessoa por um Estado à jurisdição de outro, conforme previsto em tratado, convenção ou direito interno. Ou, nos dizeres de Mazzuoli:

"A extradição envolve sempre dois Estados soberanos, sendo ato de cooperação entre ambos na repressão internacional de crimes, diferentemente do que o Estatuto de Roma chamou de entrega, onde a relação de cooperação se processa entre um Estado e o próprio Tribunal." ${ }^{, 185}$

O argumento aqui de diferenciação entre extradição e entrega é válida exatamente para facilitar a cooperação entre os Estados e o TPI, além de evitar alegações de inconstitucionalidade por parte desses, prejudicando o Estatuto de Roma e a própria funcionalidade do Tribunal. Muitos Estados prevêem a não-extradição de nacionais por acreditar que possa haver injusta decisão por parte de tribunal estrangeiro para com o nacional extraditado, confiando então na jurisdição nacional para lidar com o caso. Tal argumento não é válido para com o TPI, pois os crimes já estão definidos

\footnotetext{
${ }^{183}$ MIRTÔ, Fraga. O novo estatuto do estrangeiro comentado. Rio de Janeiro. Ed ${ }^{a}$. Forense, 2000, p. 286-287.

${ }^{184}$ MAZZUOLI, op. cit., p. 77.

${ }^{185}$ MAZZUOLI, op. cit., p.79
} 
no Estatuto de Roma, tratando-se de órgão internacionalmente reconhecido para lidar com os crimes por ele previstos, tido como detentor das normas processuais mais avançadas para lidar com as violações de direitos humanos e composto por juízes de diversas nacionalidades, o que contribui para a manutenção da imparcialidade do Tribunal.

Sobre o tema já se posicionou o Estado brasileiro, através do Anteprojeto para implementação do Estatuto de Roma, nos artigos 118,119 e 120, que regula acerca dos pedidos de extradição e entrega, reconhecendo a prevalência deste sobre o primeiro, quando conflitantes. ${ }^{186}$

\subsection{Reserva Legal}

Com relação ao princípio da reserva legal, previsto no art. $5^{\circ}$ da $\mathrm{CF} / 88$, vale dizer que não há qualquer incongruência com o disposto no Estatuto de Roma (arts.12, 21 e 24). Os delitos elencados no Estatuto baseiam-se na anterioridade de Tratados e Convenções (ex.: Convenções de Genebra e Haia sobre genocídio e direito humanitário, Convenção sobre Crimes de Guerra, princípios decorrentes dos Tribunais Militares pós $2^{\mathrm{a}}$ Guerra e Tribunais ad hoc, Resolução 177 da ONU, etc.) para legitimar a atuação do Tribunal Penal Internacional.

Sobre o tema, Bassiouni ${ }^{187}$ afirma que o conceito de reserva legal não pode ser aplicado no mesmo sentido estrito que é percebido no direito interno. Assim, os crimes contra a paz já estariam previstos no Direito Internacional (Pacto de Briand-Kellog); quanto aos crimes de guerra e

\footnotetext{
${ }^{186}$ RODAS, João Grandino. Entrega de nacionais ao Tribunal Penal Internacional. Revista CEJ, n.11. Brasília. Ed ${ }^{\mathrm{a}}$. CJF, 2000, p.32-35.

${ }^{187}$ BASSIOUNI, M. Cherif. Crimes against humanity in international criminal law. $2^{\mathrm{a}}$ ed., Haia: Klwer, 1999, pp. 129-130
} 
contra a humanidade, estes já estariam previstos nos inúmeros tratados e convenções internacionais sobre o tema. Afora isso, já havia uma condenação moral sobre o tema, fazendo necessário uma interpretação do princípio da legalidade, já que o interesse internacional prevalece em situações assim, onde o rigor técnico tem que ser posto de lado, como aconteceu nos tribunais militares, por exemplo.

Sobre o tema, o ICTY afirmou, como previamente esclarecido, que o princípio da reserva legal pretende proteger apenas as pessoas de serem protegidas por atos os quais os agentes tinham por lícitos no momento em que praticaram. Fatos tidos por delituosos no direito costumeiro internacional não serão passíveis de proteção deste princípio, pois foram reprimidos pelo próprio direito costumeiro internacional e por tratados e convenções internacionais. Por fim, tem-se que no direito internacional o conceito de lei não é adotado em sentido estrito, mas também aborda os costumes e princípios gerais de direito, que sempre recriminaram determinadas condutas, muito antes de virem a ser reprimidos sob forma de lei, estatuto ou qualquer outra fonte escrita. Sobre o tema, afirma Carlos Eduardo Adriano Japiassú ${ }^{188}$ :

"Direito Penal Internacional e legalidade, pois, não são incompatíveis, não podendo se sustentar os argumentos favoráveis ao costume. Espera-se que essa formalização decorrente das regras determinadas na capital italiana reduza as incertezas e aproxime, neste particular, as exigências do direito interno e as do Direito Internacional.

Mais que isso, com o advento da legislação de implementação, tal problema, que surgiu quanto à discussão sobre a compatibilidade entre Tratado de Roma e Constituição Brasileira, de uma vez por todas, estará superado, visto que haverá a cominação da pena para cada umas das condutas previstas no Estatuto."

\footnotetext{
188 JAPIASSÚ, Carlos Eduardo Adriano. Possibilidades e Desafios de Adequação do Estatuto de Roma à Ordem Constitucional Brasileira, in Tribunal Penal Internacional - Possibilidades e desafios, Rio de Janeiro, Ed ${ }^{\mathrm{a}}$. Lumen Iuris, p. 213.
} 


\subsection{Prisão Perpétua}

Com relação à previsão de pena de prisão perpétua no ordenamento jurídico do TPI (art.77), diversos criminalistas e estudiosos do direito internacional público vêm chegando à conclusão de que a limitação constitucional brasileira (CF art. $\left.5^{\circ}, \mathrm{XVII}, \mathrm{b}\right)$ à pena em si não abrange os crimes de interesse internacional, ${ }^{189}$ cujo interesse é suscitado devido à gravidade do crime cometido, que atinge não só a ordem internacional, mas afeta também a comunidade de Estados. Sobre o tema, Antônio Capachuz de Medeiros ${ }^{190}$ disserta:

“A proibição constitucional da pena de caráter perpétuo restringe apenas o legislador interno brasileiro. Não constrange nem legisladores estrangeiros, nem aqueles que labutam na edificação do sistema jurídico internacional. (...) Parece-nos, pois, convincente a tese que sustenta que a colisão entre o Estatuto de Roma e a Constituição Federal, no que diz respeito à pena de prisão perpétua, é aparente, não só porque aquele visa a reforçar o princípio da dignidade da pessoa humana, mas porque a proibição prescrita pela Lei Maior é dirigida ao legislador interno para os crimes reprimidos pela ordem jurídica pátria, e não aos crimes contra o Direito das Gentes, reprimidos por jurisdição universal."

Outro fator a ser estudado sobre o tema é o do princípio da prevalência de tratado internacional sobre direitos humanos. Tal princípio não se adequaria à realidade, pois a lei nacional seria mais benéfica ao réu. Assim, não haveria como se adequar, no que tange a esse ponto, a CF/88 ao Estatuto de Roma.

Sobre o tema, diversos autores atentaram sobre o fato de que o Brasil prevê em seu ordenamento a pena de morte em caso de guerra. Como as penas do Tribunal estão eminentemente vinculadas a crimes cometidos em

\footnotetext{
${ }^{189}$ PEREIRA, Carlos Frederico de Oliveira. Implementação do Estatuto de Roma e Aplicação Direta, in Tribunal Penal Internacional - Possibilidades e desafios, Rio de Janeiro, Ed ${ }^{\mathrm{a}}$. Lumen Iuris, p. 225.

${ }^{190}$ MEDEIROS, Antônio Capachuz de. O que é Tribunal Penal Internacional. Brasília, 2000, Comissão de Direitos Humanos da Câmara dos Deputados, p. 15.
} 
período de guerra ou conflitos armados, não haveria que se falar em incompatibilidade entre o Estatuto e a $\mathrm{CF} / 88$, posto que quem pode mais também pode menos.

\subsection{Coisa Julgada}

Trata o caso de situação na qual uma pessoa sujeita à jurisdição do TPI já ter sido julgada pelo ordenamento jurídico brasileiro, situação esta em que cessaria a competência do TPI (art. $20 \S 3^{\circ}$; ne bis in idem). O próprio tribunal reconhece que, em situações assim, sua competência, que é sempre subsidiária, cessa.

As exceções estão previstas no próprio Estatuto de Roma, e ocorrem quando o processo no tribunal nacional em questão tenha por objetivo subtrair o indivíduo da competência do TPI ou não tenha sido conduzido de maneira imparcial e independente.

Outro fato interessante é o de que o TPI possui o direito de reexaminar as questões já decididas em último grau pelas instâncias nacionais competentes (art.17); assim, pode o TPI reexaminar as questões decididas pelo STF. Segundo Mazzuoli ${ }^{191}$ :

"Neste caso, sem dúvida, a norma constitucional brasileira deve ceder perante a jurisdição do TPI nos mesmos termos em que a norma do inc. XVLII, alínea b, do art. $5^{\circ}$ da Constituição cede frente à possibilidade de prisão perpétua prevista pelo Estatuto de Roma de 1998."

Mesmo assim, passados 12 anos após a implementação do Tribunal Penal Internacional e discutida tantas vezes a compatibilidade ou não do ordenamento jurídico brasileiro ao ordenamento jurídico do TPI, ainda persistem dúvidas, encontrando-se a doutrina brasileira dividida em acatar a

\footnotetext{
${ }^{191}$ MAZZUOLI, op. cit. p.89.
} 
compatibilidade, tendo como pano de fundo a preponderância do TPI em questões humanitárias, previsto na CF/88 (hoje o Estatuto de Roma e o TPI seguem a tendência natural de internacionalização dos direitos humanos, fato este que gera o entendimento de que qualquer violação a esses direitos extrapola os limites da jurisdição nacional), ou em acatar sua inconstitucionalidade, afirmando que não é possível adequar $\mathrm{CF} / 88$ às regras do Tribunal e que a própria adesão ao Estatuto, por si só, fere a soberania nacional.

Seja como for o TPI é hoje uma realidade da qual o Brasil faz parte como membro, incluindo-se no seio das nações que cooperam juridicamente entre si a fim de garantir que novas violações aos direitos humanos sejam evitadas e que seus violadores sejam detidos e julgados, conforme a lei, seja ela nacional ou internacional. 


\section{CONCLUSÃO}

Espinhoso foi o caminho perpassado pela humanidade até o advento deste Tribunal Penal Internacional. Difícil é também pensar que, fruto de tanta discórdia e intolerância ao longo dos séculos, bem como anseios e busca por justiça, o TPI seja algo discutido há tanto tempo, e no entanto, seja algo tão novo. Sua criação coincide com um período de amadurecimento das relações internacionais, bem como com uma reinvenção do conceito de direito internacional, a começar pela noção de soberania.

O Tribunal é, sob todos os aspectos, um avanço na jurisdição internacional e na proteção dos direitos humanos. É um tema que volta a ganhar fôlego e suscita muitas questões, que englobam diversas áreas do direito (constitucional, internacional público, processual penal, direitos humanos etc.). Seu surgimento é, antes de mais nada, um conjunto de diversos fatores (histórico, sociológico, político, legal) que se juntaram basicamente a partir do século XIX, rumo a um caminho aparentemente sem volta, qual seja, o da internacionalização de determinados crimes, fazendo com que determinadas condutas deixem de ser tratadas como questão doméstica para aproximar os Estados em prol de uma devida proteção aos direitos humanos.

Para explicar esse longo caminho pelo qual passou o TPI, tomei por necessário fazer um estudo inicial, embora não muito aprofundado sobre a história em torno da jurisdição penal internacional, que é fruto direto da injustiça (como reação), no seu mais amplo conceito, bem como na evolução das relações diplomáticas, comerciais e jurídicas presenciadas pela humanidade, principalmente nos últimos cem anos. 
Foi o século XX, exatamente, responsável pelo desencadeamento de fatores que, muito lentamente, foram se intensificando até se tornar um movimento consciente em busca de um tribunal penal permanente como única forma de se levar à justiça aqueles que poderiam muito bem ser descritos como os piores seres humanos. A rápida evolução tecnológica pela qual passou o breve século XX, nas palavras de um historiador famoso, culminaram numa intensificação em busca de recursos para alimentar a expansão econômica decorrente. A consequiência inevitável foi uma intensificação na competição por espaços vitais pelas nações mais ricas do mundo, que desencadeou as duas grandes guerras de nossa história, tão desastrosas sob vários aspectos, mas diretamente responsáveis pela implementação deste Tribunal. A Europa arrasada pelas guerras foi unida pelo Tratado de Londres (que estabeleceu os alicerces para se julgar os criminosos de guerra) e pelo Plano Marshall (que integrou Estados com regimes jurídicos semelhantes, plantando a semente de uma maior cooperação jurídica entre eles, a ser seguida posteriormente pelo resto do mundo), sendo determinante para a efetiva tutela dos direitos humanos nos anos vindouros.

Ao passar pelos aspectos históricos e sociológicos, fui em direção aos alicerces de legitimidade do TPI, encabeçados pelo Estatuto de Roma, tratado este que o Brasil aderiu em 2000. Tentei explicar os mecanismos por trás da aprovação do Tratado, bem como as disputas políticas correlacionadas, os pontos de vistas discutidos, as doutrinas jurídicas expostas, bem como o resultado final. O Estatuto pode não ter saído perfeito, mas certamente representa um marco na nossa História.

Não podia deixar de falar também no aspecto jurídico-internacional do tema, os chamados pressupostos da cooperação jurídico-internacional, nem de elucidar os fundamentos do TPI. Alguns dos elementos dispostos nesses capítulos originam-se de idéias e princípios expostos há séculos, como o próprio conceito de paz perpétua, ou até milênios, como a 
cidadania. Mais um exemplo da importância da História para o tema desta monografia.

A parte final é destinada aos crimes previstos pelo TPI, bem como concernente a possíveis dificuldades encontradas pelo ordenamento jurídico brasileiro em adequar-se ao Estatuto de Roma. São temas recentes, ainda não muito debatidos pela doutrina nacional, nem clareados pela jurisprudência. Mas pouco a pouco dúvidas estão sendo esclarecidas e a participação do Estado brasileiro no cenário penal internacional só tende a crescer, bem como a dos demais Estados, fruto do amadurecimento das relações entre si, bem como da redefinição de alguns conceitos, tais como a soberania e o próprio papel do indivíduo no cenário internacional.

Passados 12 anos de sua criação, o TPI ainda tem uma longa caminhada a ser feita se quiser prestar-se aos motivos aos quais fora concebido. Porém, nesse diminuto decorrer de tempo já podemos vislumbrar contribuições deste Tribunal ao ordenamento jurídico internacional. Alargou-se a responsabilidade criminal individual, negou-se a prerrogativa de cargo ou posição oficial no governo como excludente de responsabilidade, consagrou-se (de forma escrita, onde antes vigorava o costume) os princípios da imputabilidade, presunção de inocência, reserva legal, irretroatividade da lei penal, reserva legal, dentre outros.

A mínima intervenção, a qual o TPI exerce quase que de forma dogmática, devido ao princípio da complementaridade, contribuiu para alavancar a credibilidade do Tribunal na esfera internacional, deixando as situações internacionalmente consideradas menos repulsivas exclusivamente a cargo da ordem jurídica doméstica. Também suplanta os polêmicos tribunais ad hoc estabelecidos pelo Conselho de Segurança da ONU, que embora importantes para o processo de crescimento do direito penal internacional, minavam a legitimidade da mesma, devido ao caráter político dos mesmos. 
Por tais motivos, o Tribunal Penal Internacional faz-se hoje um instrumento necessário e extremamente importante para a manutenção da ordem e da justiça no cenário internacional. Sua presença se legitima pelo expressivo número de ratificações ao Estatuto de Roma. Em que pese alguns preceitos jurídicos terem ficado de fora do tratado, a fim de se obter o maior número possível de adesões, podemos dizer que a própria existência do Tribunal é, por si só, uma vitória. É uma vitória não só de inúmeros juristas, políticos, diplomatas, chefes de governo e Estado, autoridades em geral que se dedicaram em tornar possível a implementação de um sonhado tribunal penal permanente na esfera internacional, mas também das inúmeras vítimas dos inúmeros conflitos pelos quais passou a humanidade, que não tiveram o direito de serem escutadas, socorridas ou até reconhecidas enquanto pessoas, detentoras de direitos e obrigações nas esferas nacional e internacional. É uma vitória da comunidade internacional sob todos os aspectos, seja pela fortalecimento da intervenção humanitária em áreas de conflitos, seja pelo incremento do acesso à justiça, seja pela própria justiça em si, que hoje faz-se possível, embora que de forma ainda suficiente, verdade seja dita, ao assegurar a proteção a certos direitos inalienáveis e caros a todos os seres humanos, bem como partir do pressuposto de que nenhum violador de direitos humanos estará livre, seja quem for, de um dia vir a responder por seus atos frente à Justiça. O Tribunal Penal Internacional é, ouso dizer, uma vitória da humanidade contra aquilo que ela tem de pior e que sempre restou impune. Até então. 


\section{Bibliografia}

ACCIOLY, Hildebrando; SILVA, G.E. do Nascimento e. Manual do Direito Internacional Público. 14 ${ }^{\mathrm{a}}$ Ed. São Paulo: Saraiva, 2000. p.111

APOSTOLOVA, M. Stefanova. Quem libertou o gênio ? Nacionalismo e conflito étnico na ex-Iugoslávia, 1991-1995. Brasília: IPR/UNB, 1996

ARAUJO, Jr., João Marcello. Tribunal penal permanente, instrumento de garantia dos direitos fundamentais (processo legislativo histórico e características). Parecer apresentado ao Instituto dos Advogados Brasileiros, indicação $n^{\circ}$ 036/98, Rio de Janeiro, 1999

ARENDT, Hannah. Eichman em Jerusalém: um relato sobre a banalidade do mal. São Paulo: Companhia das Letras, 1999.

BACIGALUPO, Felipe. Principios de derecho penal: parte general. $5^{\mathrm{a}} \mathrm{ed}$, Madrid: Akal, 1998, p.55

BARRETO, Vicente. O conceito moderno de cidadania. In: Revista de Direito Administrativo, ${ }^{\circ} 192$, Rio de Janeiro. Ed. ${ }^{a}$ Renovar, 1993, p. 31

BASSIOUNI, M. Cherif. Crimes against humanity in international criminal Law. $2^{a}$ ed., Haia: Klwer, 1999, p.129/130.

BASSIOUNI,M. Cherif. Chronology of efforts to establish na International Criminal Court. In: Nouvelles Études Penales, $n^{\circ} 10$, Toulouse, Érès, 1993, p. 22 .

BASSIOUNI, Le fonti e Il contenuto del diritto penale Internazionale, p. $104 / 105$

BASSIOUNI, M. Cherif. Note explicative sur Le Statut de la Cour Pénale Internationale - ratification et mise en oeuvre dans les legislations nationals - Révue international de droit penal. Toulouse:Érès, 2000, p.4, nota 14)

Bassiouni, M. Cherif. The time has come for an International Criminal Court. In: Indiana International \& Comparative Law Review. Vol.1, $\mathrm{n}^{\circ} 1$, Spring 1991, p.1.

BECCARIA, Cesare. Dos delitos e das penas. $2^{\mathrm{a}}$ ed.,São Paulo: RT, 1997, p.33

BERKLEY, Bill: Sounds of violence. The new Republic. New York: Times book, 1998 
BOBBIO, Norberto. Direito e Estado no pensamento de Emanuel Kant. Brasília, UNB, 1997, p.160.

BONAVIDES, Paulo. Ciência Política. São Paulo: Malheiros, 1997, p.123/124.

BOURDON, William. La Cour Pénale Internationale. Paris: Éditions su Seuil, 2000

CARLOS, Canêdo. O genocídio como crime internacional. Belo Horizonte: Del Rey, 1999, p.68. HUET, André; KOERING-JOULIN, Renné. Droit Pénal International. Paris: PUF, 1994, p.57

CARRILLO SALCEDO, Juan Antonio. Curso de Derecho Internacional Público - Introducción a su Estructura, Dinámica y Funciones. Madrid: Tecnos, 1996, p.74

CHAYES, Abram. The New Sovereignty. Apud Piovesan, F. O tribunal internacional e os crimes contra a humanidade. Mimeo (não publicado), 2000, p.5.

CLÉMENT, Zlata Drnas de. Principio de Complementariedad en el Estatuto de la Corte Penal Internacional: incoherencias sistêmicas, Anuario Argentino de Derecho Internacional, v.11, p.51, Córdoba, 20012002.

CLÈVE, Clémerson Merlin. Teoria do direito constitucional. São Paulo. $\mathrm{Ed}^{\mathrm{a}}$. Acadêmica, 1993, p.16

COSTA, Rodrigo de Souza. Terrorismo: uma abordagem crítica. In: Revista de Ciências Jurídicas. Vol.1, ${ }^{\circ}{ }^{1}$, Rio de Janeiro: ICJ/UVA, 2002, p.194.

DOTTI, René Ariel. Curso de Direito Penal - Parte Geral. Rio de Janeiro: Forense, 2001, p. 283.

FAROOK, Hassan (Relator). The origins, development and expanding scope of international criminal law. In: New horizons in international criminal law. Toulose: Érès, 1985,p.35.

FERRAJOLI, Luigi. Derecho y razón. Teoria del garantismo penal. $5^{\text {aed.; }}$ Madrid: Trotta, 2001, p.857.

FERRAJOLI, Luigi. La soberania en el mundo moderno. In derechos y garantias. La ley del más débil. Madri: Trotta, 1999, p.125 
FRAGOSO, Heleno Cláudio. Terrorismo e criminalidade política. Rio de Janeiro: UERJ (tese), 1980, p.49.

GIL, Gil. Derecho penal internacional, p.67

GIL GIL. El genocídio y otros crímenes internacionales, p.86

GLASER, Stefan. Infraction internationale: sés élements constituifs et ses aspects juridfiques. Paris: Librairie Génerale de Droit et de Jurisprudence, 1957, p.41 e ss.

GOLDSTONE, R.: Cincuenta años despues de Nuremberg: um nuevo tribunal penal internacional para crimines que atentam contra los derechos humanos. Revista Memoria, Nuremberg, n.8,p.4-11,1996.

GOMES, Luiz Flávio. Sobre a garantia da legalidade em direito penal. In: O sistema interamericano de proteção dos direitos humanos. São Paulo: RT, 2000, p.302/306

Herbst, S.: Los derechos humanos ante las cortes: los juicios de Nuremberg y su significado actual. Revista Memória, Nuremberg, n.8,p. 12-20, 1996

HOBSBAWN, Eric. Era dos extremos: o breve século XX:1914-1991. 10a Edição. Companhia das Letras, 2008, p.30.

HOLT, James Clarke. Magna Carta. $2^{\mathrm{a}}$ ed., Cambridge: Cambrisge University Press, 1995, p.460/461

HUNGRIA, Nelson. Genocídio. In: Comentários ao Código Penal. Volume VI, $4^{\mathrm{a} e d}$., Rio de Janeiro: Forense, 1958, p.367/368.

JAPIASSÚ, Carlos Eduardo Adriano. O Tribunal Penal Internacional: a Internacionalização do Direito Penal. Rio de Janeiro: Editora Lumen Juris, 2004, p.xvii.

JAPIASSÚ, Carlos Eduardo Adriano. Possibilidades e Desafios de Adequação do Estatuto de Roma à Ordem Constitucional Brasileira, in Tribunal Penal Internacional - Possibilidades e desafios, Rio de Janeiro, $\mathrm{Ed}^{\mathrm{a}}$. Lumen Iuris, p. 201.

JARDIM, Tarciso Dal Maso. O Tribunal Penal Internacional e sua importância para os direitos humanos, p.22, nota $\mathrm{n}^{\circ} 18$.

KANT, Emanuel. A Paz Perpétua, Ed Martins Fontes 
LANGHMANI, Slim. Le tribunal Pénal International pour Le Rwanda. In: Justice et jurisdictions internationales. Paris: Pedone, 2000

MAIA, Marrielle, Tribunal Penal Internacional:Aspectos institucionais, jurisdição e princípio da complementaridade, $1^{\mathrm{a} e d i c ̧ a ̃ o, ~ E d i t o r a ~ D e l ~}$ Rey,2005,p.47

MAUSS, Marcel. Ensaio sobre a dádiva, Ed. Edições 70.

MAZZUOLI, Valerio de Oliveira. Tribunal Penal Internacional e o Direito Brasileiro. V.3. Editora Revista dos Tribunais, $2^{a}$ edição, $p 23$.

MEDEIROS, Antônio Capachuz de. O que é Tribunal Penal Internacional. Brasília, 2000, Comissão de Direitos Humanos da Câmara dos Deputados, p. 15 .

MELLO, Celso D. de Albuquerque, Curso de Direito Internacional Público, 15 a ed. Renovar, Rio de Janeiro, 2004.

MESTIERI, João. Teoria elementar do direito criminal, parte geral. Rio de Janeiro: Editora do autor, 1990, p.117

MIRTÔ, Fraga. O novo estatuto do estrangeiro comentado. Rio de Janeiro. $\mathrm{Ed}^{\mathrm{a}}$. Forense, 2000, p. 286-287.

MUELLER, Gerhard O. W.. The nomination by ISPAC to award the 1999 Nobel Peace Prize to Professor M. Cherif Bassiouni. In: ICC ratification and national implementing legislation, Toulouse: Érès, 1999, p.IX.

NILO, Batista. Introdução crítica ao direito penal brasileiro. $3^{\mathrm{a}} \mathrm{ed}$., Rio de Janeiro: Revan, 1996, p.65

PALMA, Alessandra. I crimini contro l'umanitá e Il Tribunale Penale Internazionale. Ferrara: Università Degli Studi di Ferrara, Facoltà di Giurisprudenza, 2000, p.18.

PEREIRA, Carlos Frederico de Oliveira. Implementação do Estatuto de Roma e Aplicação Direta, in Tribunal Penal Internacional - Possibilidades e desafios, Rio de Janeiro, Ed ${ }^{\text {a }}$. Lumen Iuris, p. 225.

REALE, Miguel. Teoria do direito e do Estado. São Paulo: Martins Fontes, 1960, p.127

RIPOLLÉS, Antonio Quintano. Tratado de derecho penal internacional e internacional penal. Tomo I, Madrid: Consejo Superior de Investigaciones Científicas, Instituto "Francisco de Vitoria", 1995, p.95. 
RODAS, João Grandino. Entrega de nacionais ao Tribunal Penal Internacional. Revista CEJ, n.11. Brasília. Ed ${ }^{\mathrm{a}}$. CJF, 2000, p.32-35.

ROXIN, Claus. Derecho Penal, parte general, tomo I. Fundamentos. La estructura de la teoria del delito. Madrid: Civitas, 1999, p.137

SCHABAS, William A. An introduction to the International Criminal Court, p.30

SCHEFFER, David J.. The United States and the International Criminal Court. 93 American Journal of International Law, p.20.

TAQUARY, Eneida Orbage de Britto. Tribunal Penal Internacional \& A Emenda Constitucional 45/04 (Sistema Normativo Brasileiro). Curitiba: Juruá Editora, 2008, p.13.

TAVERNIER, P., La experiência de los tribunales penales internacionales para ex-Iugoslávia y Ruanda. Revista Internacional de la Cruz Roja 144, P.645-653.

TORRES, Ricardo Lobo. Cidadania multidimensional na era dos direitos. In: Teoria dos direitos fundamentais. Rio de Janeiro. Ed. ${ }^{a}$ Renovar, 1999, p. 244

TRINDADE, Antonio Augusto Cançado. Tratado de direito internacional dos direitos humanos. Porto Alegre. Ed. ${ }^{a}$ Sergio Antonio Fabris, 1997, p.27

TZU, Sun. A arte da guerra. São Paulo: Ed ${ }^{a}$. Cultura, 2000, p.17

http://www.priberam.pt/dlpo/default.aspx?pal=fam\%C3\% ADlia (acessado dia 29/09/2010)

http://pt.wikipedia.org/wiki/Pr\% C3\% A9-hist\% C3\% B3ria (acessado dia 29/09/2010)

http://www.middle-ages.org.uk/magna-carta.htm (acessado em 29/09/2010)

http://pe360graus.globo.com/obj/107/77938.pdf (acessado em 29/09/2010)

http://www.rolim.com.br/2002/_pdfs/0611.pdf (acessado em 29/09/2010) http://www.constitution.org/usdeclar.pdf (acessado em 29/09/2010) 
http://www.ibge.gov.br/ibgeteen/datas/cruz_vermelha/comosurgiu.html (acessado em 29/09/2010)

http://www.dhnet.org.br/educar/redeedh/anthist/gen1864.htm (acessado em 29/09/2010)

http://portal.mj.gov.br/sedh/ct/legis_intern/ddh_bib_inter_universal.ht m (acessado em 29/09/2010)

http://www.rolim.com.br/2002/_pdfs/0620.pdf (acessado em 29/09/2010) http://pt.wikipedia.org/wiki/Gustave_Moynier (acessado dia 29/09/2010) http://pt.wikipedia.org/wiki/Pacto_Briand-Kellogg (acessado em 29/09/2010)

http://www.uff.br/pgcp/page0/files/nelsongasparinjr.pdf (acessado em 04/10/2010)

http://avalon.law.yale.edu/imt/imt10.asp (acessado em 04/10/2010)

http://pt.wikipedia.org/wiki/Tribunal_Militar_Internacional_para_o_E xtremo_Oriente (acessado em 05/10/2010)

http://pt.wikipedia.org/wiki/Hirohito (acessado em 05/10/2010)

http://www.onu-brasil.org.br/ (acessado em 05/10/2010)

http://www.dw-world.de/dw/article/0,,332295,00.html (acessado em 05/10/2010)

http://www.artigos.com/artigos/sociais/direito/o-tribunal-penalinternacional-e--o-julgamento-dos-horrores-de-slodoban-milosevic12004/artigo/ (acessado em 05/10/2010)

http://www.onu-brasil.org.br/doc4.php (acessado em 05/10/2010)

http://www.article19.org/work/regions/latin-america/FOI/pdf/onupacto_inter.dir.civ.pol.pdf (acessado em 05/10/2010; grifos meus na transcrição)

http://www.icty.org/x/file/Legal\%20Library/Statute/statute_sept09_en. pdfhttp://www.icty.org/sid/135 (acessados em 05/10/2010)

http://pt.wikipedia.org/wiki/Ruanda (acessado em 09/10/2010) 
http://www.usp.br/jorusp/arquivo/2008/jusp822/pag03.htm (acessado em 09/10/2010)

http://www.unictr.org/Cases/tabid/204/Default.aspx (acessado em 09/10/2010)

http://www.fd.uc.pt/CI/CEE/OI/TPI/Estatuto_Tribunal_Penal_Interna cional.htm

http://noticias.terra.com.br/mundo/noticias/0,,OI4712627-EI294,00-

ONU+disse+que+Exercito+de+Ruanda+teria+planejado+massacre+a+ hutus.html (acessado em 09/10/2010)

http://www.iccnow.org/?mod=rome\&lang=es (acessado em 10/10/2010)

http://neiarcadas.wordpress.com/2010/06/05/conferencia-de-revisao-doestatuto-de-roma-do-tribunal-penal-internacional-por-cesar-yip/ (acessado em 10/10/2010)

http://iccnow.org/?mod=issues (acessado em 11/10/2010)

http://www.dji.com.br/decretos/2002-004388/2002-004388.htm (acessado em 11/10/2010)

http://www.jusbrasil.com.br/legislacao/99584/decreto-4388-02 (acessado em 10/10/2010)

http://www2.mre.gov.br/dai/dtrat.htm (acessado em 13/10/2010)

http://www.uff.br/direito/images/stories/ARQUIVOS_PARA_DOWNL OAD/artigos_em_pdf/R_CEJ_Coopera_o.pdf (acessado em 13/10/2010)

http://www.fd.uc.pt/CI/CEE/OI/TPI/Estatuto_Tribunal_Penal_Interna cional.htm (acessado em 13/10/2010)

http://www.stf.jus.br/portal/cms/verTexto.asp?servico=legislacaoRegim entoInterno (acessado em 13/10/2010)

http://www.planalto.gov.br/ccivil/leis/L6815.htm (acessado em $13 / 10 / 2010)$

http://www.revistahistoria.ufba.br/2010_1/a01.pdf (acessado em 14/10/2010; p.7)

http://www.leonildocorrea.adv.br/curso/org1.htm (acessado em 14/10/2010) 
http://pt.wikipedia.org/wiki/Jean_Bodin (acessado em 15/10/2010)

http://www.uj.com.br/publicacoes/doutrinas/7009/Breve_Analise_dos_ Tratados_Internacionais_no_Direito_Brasileiro (acessado em $15 / 10 / 2010)$

http://www.historiasiglo20.org/europortug/maastricht.htm (acessado em 15/10/2010)

http://www.dhnet.org.br/direitos/anthist/decbill.htm (acessado em 17/10/2010) http://www.clubjus.com.br/?artigos\&ver=22204.32488 (acessado em 17/10/2010)

http://www.fd.uc.pt/CI/CEE/OI/TPI/Estatuto_Tribunal_Penal_Interna cional.htm (acessado em 17/10/2010)

http://www.fd.uc.pt/CI/CEE/OI/TPI/Estatuto_Tribunal_Penal_Interna cional.htm (acessado em 18/10/2010)

http://www.preventgenocide.org/lemkin/AxisRule1944-1.htm (acessado em 20/10/2010)

http://www.dhnet.org.br/direitos/sip/onu/genocidio/conv48.htm (acessado em 20/10/2010)

http://www2.mre.gov.br/dai/genocidio.htm (acessado em 20/10/2010) http://pt.wikipedia.org/wiki/C\%C3\%B3digo_de_Manu (acessado em 20/10/2010) 